\title{
Bullets, Breeding, and Biodiversity: An analysis of trophy hunting in South Africa's green wildlife economy
}

Dave E. Knieter

deknieter@mix.wvu.edu

Follow this and additional works at: https://researchrepository.wvu.edu/etd

\section{Recommended Citation}

Knieter, Dave E., "Bullets, Breeding, and Biodiversity: An analysis of trophy hunting in South Africa's green wildlife economy" (2020). Graduate Theses, Dissertations, and Problem Reports. 7543.

https://researchrepository.wvu.edu/etd/7543

This Dissertation is protected by copyright and/or related rights. It has been brought to you by the The Research Repository @ WVU with permission from the rights-holder(s). You are free to use this Dissertation in any way that is permitted by the copyright and related rights legislation that applies to your use. For other uses you must obtain permission from the rights-holder(s) directly, unless additional rights are indicated by a Creative Commons license in the record and/ or on the work itself. This Dissertation has been accepted for inclusion in WVU Graduate Theses, Dissertations, and Problem Reports collection by an authorized administrator of The Research Repository @ WVU.

For more information, please contact researchrepository@mail.wvu.edu. 
Bullets, Breeding, and Biodiversity: An analysis of trophy hunting in South Africa's green wildlife economy

Dave Knieter, PhD.

Dissertation submitted to the Eberly College of Arts and Sciences at West Virginia University

in partial fulfillment of the requirements for the degree of

Doctor of Philosophy in

Geography

Brent McCusker, PhD., Chair

Karen Culcasi, PhD.

Bradley Wilson, PhD.

Jamie Shinn, PhD.

Robert Maxon, PhD.

Department of Geology and Geography

Morgantown, West Virginia

2020

Key words: trophy hunting, green economy, production of nature, neoliberal nature, breeding, political ecology, capitalism, critical conservation, animal studies

Copyright 2020 Dave Knieter 


\section{ABSTRACT \\ Bullets, Breeding, and Biodiversity: An analysis of trophy hunting in South Africa's green wildlife economy}

\section{Dave Knieter, PhD.}

Using a political ecology framework, I explore the relationship between international trophy hunting and South Africa's private wildlife ranching industry. I interrogate the intersection of colonialism, capitalism, and conservation, which at its nexus are the discourses, policies, and logics that greenwash the production of nature. The proceeding chapters highlight a number of specific themes that problematize the neoliberalization of nature, including (i) the contradictions of imposing a market value to nonhumans; (ii) the operationalization of socioeconomic and environmental frameworks to justify trophy hunting and the breeding of nonhumans for profit; (iii) the use of African landscape and wildlife imagery to market trophy hunting; and (iv) how industry advocates advance a politics of scale, fear, and difference to strengthen cultural identities and cultivate a sense of belonging. Data reveal that private wildlife ranching paradoxically privileges some species over others, which means that some nonhuman lives are more intensely manipulated and violently exploited than others. Consequently, this dissertation calls for greater consideration of nonhuman sentience and complexity in decisions regarding wildlife conservation rather than an utilitarian ethos guided by colonial epistemologies and neoliberal logics that abstract nonhuman lives into parts for capitalist accumulation. 
Table of Contents

Introduction...................................................................... page 1

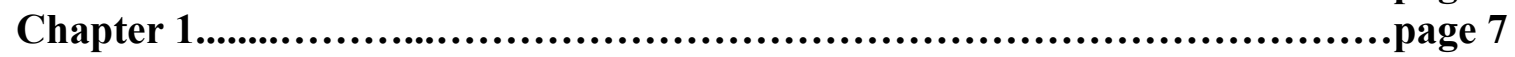

Chapter 2........................................................................page 37

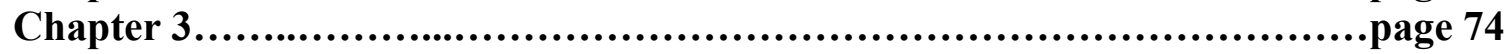

Conclusion.......................................................................page 104 


\section{Introduction}

"The art of war is a natural art of acquisition, for the art of acquisition includes hunting, an art which we ought to practice against wild beasts, and against men who, though intended by nature to be governed, will not submit; for war of such a kind is naturally just."

(Coetzee quoting Aristotle; 1999: 155)

While walking through the veld in the Northwest Province of South Africa, a well-respected and successful game farmer named Walter told me that international ecotourism and trophy hunting safaris are both rooted in colonialism. This statement struck me; it was true but hardly a fact one admitted, especially white game farmers in post-apartheid South Africa.

To be clear, early colonial conservation in South Africa grew out of racially motivated scientific discourses of environmental crisis and wildlife scarcity, which resulted in the alienation, displacement, and dispossession of indigenous and Bantu people. Excessive European colonial hunting practices caused a decline in wildlife due to off-take of ivory and commercialization (Beinart, 2003), prompting new nature-society divides to protect and regulate the off-take of certain species privileging white urban elites. Subsistence hunters were relegated to poacher status, meaning that Africans were deprived participation in the wildlife trade (Ramutsindela et al., 2016). Additionally, environmental degradation was framed as the product of poor indigenous land use practices rather than a natural byproduct of marginalization (Robbins, 2011), condemning local communities to shrinking plots of land. The results of adopting an exclusionary ethos were no different than the history of international conservation and tourism itself; resentment, resistance, and violence characterized state-local relations.

Having spent a lot of time in South Africa as a US Peace Corps Volunteer (20032005) and researcher (2013 and 2018) I've encountered not a few ahistoric and oversimplified understandings of land seizure, institutionalized racism, and uneven development. I've spoken with many white South Africans such as one particular professional hunter (2018) who said the following:

"There is more and more racism directed at whites. We are being persecuted. Why aren't the blacks? There are many more black millionaires and billionaires than whites. Why not look at them? They see the whites as privileged. But what about just figuring it out, pulling yourself up and making something for yourself."

What I came to understand over the course of one week with Walter was that he was very much aware of the ways in which conservation served as a mechanism to dispossess and marginalize African lives. The fact that white South African landowners profited from state sanctioned violence was not lost on him, which is why he was in the process of working through a 50/50 joint agreement with a community approximately $14 \mathrm{~km}$ from his game farm. Although there was no evidential record, ecological, cultural, legal, or otherwise that presented Batswanas as having once been occupants on Walter's land, he 
felt obligated to ensure that adjacent communities could benefit from his operation. The threats of expropriation without compensation and safety concerns, he admitted, also served as catalysts for initiating negotiations. The infrastructure for Walter's farm was originally built two generations before and later became a successful cattle farm where his mother honed her cattle rearing skills to become the first female in South Africa to win "Best in stud breeding." By the 1980s it was becoming increasingly difficult, however, to reap any profits from the farm due to drought and political and economic instability. Consequently, Walter and a host of other farmers began to consider transitioning from farming livestock to "farming the wild" (Carruthers, 2008). They realized that wildlife was more resilient to climatic variation than their weaker domestic counterparts.

The rationale for 'farming the wild' crystalized in the wake of South Africa's democratic transition (1994), as farmers lost agricultural subsidies and could no longer afford to pay their laborers the newly imposed minimum wage. National legislation such as the Games Theft Act (1991) smoothed the transition by granting private landowners game rights of ownership of wildlife on suitably fenced land (Cousins et al. 2010). If they could provide to the authorities that they had fenced in their wildlife satisfactorily, they were eligible for a Certificate of Adequate Enclosure from each of the provinces, a move that entitles them to subsidies as well as additional benefits (Carruthers, 2011). Walter did the arithmetic, and calculated that South Africa's emergence as a majority-led democracy would open its doors to international tourists with foreign currency. He was not wrong, as South Arica annually draws thousands of international trophy hunters that on average spend US\$10, 000 on hunting safaris (Taylor et al., 2016).

Walter's statement about colonialism originally took place in the context of criticism he heard from a New York Times journalist who was visiting him. The journalist, like me, was given the opportunity to walk through Walter's home and peruse the artifacts and photographs festooning Walter's home and office. The journalist noted how "colonial" the photos were and how Walter's livelihood did not resemble a break from the past but was rather its social and spatial reproduction. The journalist said that trophy hunting is inherently colonial, which prompted the following counterargument: "What is so different about tourism and non-consumptive conservation? They're also a legacy of colonialism. Are they not?"

While I don't disagree that all are inherently colonial, however, what makes trophy hunting distinct is the recurrent violence against nonhumans. What's particularly interesting, however, is the purpose behind Walter's pithy retort. Turning the question back on the journalist was a thinly veiled accusation meant to illustrate how the critique against trophy hunting is tantamount to 'colonial cherry picking'. More succinctly, it's either ignorant or intellectually dishonest, but either way it stems more so from an animal right's community, one "like the human-rights movement, yet another Western crusade against the practices of the rest of the world, claiming universality for what are simply its own standards" (Coetzee, 1999: 156). Walter interpreted this selective colonialism as reflective of a larger global trend to delegitimize and destabilize white landowner heritage, cultural identity, and livelihood practice. The aforementioned fold collectively into one's sense of belonging, particularly in the context of a country where white South Africans feel they are being wrongfully persecuted and marginalized in a radical campaign to ameliorate the wrongs of the past. 
Land is uniquely tied to one's identity in South Africa, but it remains mostly elusive to black South Africans. "In so far as blackness still coincides with poverty, it is constructed as an enduring identity of landlessness and dispossession in contrast to an identity of property and wealth held by whites" (Hendricks et al., 2013: 8). In South Africa's current economic and political crisis, white farmers perceive threats in security, stock theft, land restitution claims and expropriation (Carruthers, 2011). The stoking of these collective fears ostensibly reinvigorated calls for a 'taking back' of their land (Igoe and Brockington, 2007), an emboldened clamor empowering white farmers to scale up and further "consolidate and (re)-assert their claims to private property" (Brandt and Spierenburg, 2014). In this context, contestations about the establishment of trophy hunting farms become less about nature conservation and more about the original status of land and people that belong to the landscape (Carruthers, 2011).

This dissertation interrogates the spatiotemporal convergence of colonialism, capitalism, and conservation. At its nexus are the discourses, policies, logics, and language that normalize the commodification, exploitation, and abstraction of nature. I explore a number of specific themes that problematize the production of nature, including (i) the contradictions of imposing a market value to nonhumans; (ii) the operationalization of socioeconomic and environmental frameworks to justify trophy hunting and the breeding of nonhumans for profit; (iii) the use of African landscape and wildlife imagery; and (iv) industry advocates who advance a politics of fear and difference to strengthen cultural identities and cultivate a sense of belonging.

Not unlike South Africans, international trophy hunters, especially Americans, fear their 'way of life' is in danger, which is a theme I develop further in the first chapter. In this chapter I use Safari Club International's Annual Hunter's Convention as a site to examine the diffusion of right wing ideologies, myths, and discourses and how they interface with market logics and the hegemon of conventional conservation. The culmination I refer to as right wing political ecologies, which I argue greenwash the commodification of nature and the violence underpinning "sustainable use" conservation. Using informational gatherings, presentations, ribbon cutting ceremonies, videos, luncheons, auctions, and a taxidermic smorgasbord of wildlife, SCI establishes a consensus through spectacle, an agreement that only trophy hunting can resolve humanwildlife conflict, rural poverty, overpopulation, and food insecurity. The convention performs the function of consensus-making, cultural identity strengthening, and strategic marketing, resulting in an economic-driven approach to wildlife conservation that places a monetary value on individual nonhuman lives and entrenches the privatization and enclosure of nature for profit.

The second chapter links these material realities with the inception and expansion of capitalist logics in conservation. I argue that the logics underpinning the neoliberalization of nature only nurture new illogics whereby nonhumans are reduced to biocapital. South Africans can own wildlife so long as they are adequately fenced, tantalizing farmers to move beyond merely putting wild animals on their land to have them hunted for profit. Hunting wildlife, particularly on fenced land, requires a sustainable and healthy stock. To ensure a perpetual bounty to "harvest", landowners, safari outfitters, and trophy hunters have come to rely upon wildlife ranches that breed specific nonhumans with specific traits. The result has been a niche market meant to satisfy an international clientele motivated by "inches" and color variation. Producing 
nature of exceptional horn length, body size, and color, what I refer to as super species, resulted in a great accumulation of wealth for mostly white private landowners and businessmen. In essence, it turned an already cost prohibitive activity into one even more exclusive for game farmers/wildlife ranchers seeking to compete in a growing market, for local communities to access land, and for hunters seeking to add to their taxidermic collection.

As wildlife ranching has evolved it has become the backbone of South Africa's trophy hunting industry, and therefore instrumental to South Africa being the most popular trophy-hunting destination on the African continent. The third chapter highlights the reasons why South Africa remains a "preferred hunting destination" (PHASA, 2016) despite many of the trophy hunting industry's internal tensions, conflicts, and ethical dilemmas plaguing the production and commodification of nature. This chapter expands upon how the commodification of nature results in devaluing some species in favor of others, thus nurturing uneven natures and contradicting the tenets of conservation. Despite efforts and well-intentioned individuals, the nature of nature conservation in South Africa remains colonial. I argue that the reasons for this are manifold, more specifically rooted in hunter expectations, imagery and representations of Africa, marketing strategies, neoliberalism, failures of land reform, and the ability of the trophy hunting industry to foster relations with state conservation.

While the mostly white wildlife industry can legitimately claim its part in the conservation and protection of wildlife habitat, even its role in rescuing the white rhino back from the brink of extinction, it needs to address a host of contradictory conservation practices that we should expect from privatizing the production of nature. At present, some of these problems include selective breeding for trophy hunting, deliberate breeding of recessive color variations, and fragmented landscapes, causing genetic isolation of species and the disruption of migratory routes, as well as overstocking and associated land degradation, unscientific intensive captive breeding programs, and canned hunting (Cousins et al. 2010, Bothma et al. 2009, Lindsey et al. 2009). Challenged with navigating critique of its practices, programs, and policies within perceived and/or real environmental, political and economic crises, the private wildlife industry must adapt to legitimize and conserve itself. These problems are addressed differently according to specific non-governmental organizations that operationalize neoliberal economic and environmental discourses and legislation to maintain their relevance and compete in a regionally saturated market. I place these discourses and laws in historical context, drawing on colonial land policies and the broader political economy.

Violence against nonhumans is green washed through language, discourse, and legislation that frame nature in economic terms, which fosters uneven consequences. Private wildlife ranching, despite producing increased wildlife habitat, paradoxically privileges some species over others, which means that some nonhuman lives end more abruptly and violently than others. This occurs on account of shifts in economic value, leaving nonhumans at the mercy of the market. Even the most iconic of species are not protected from the broader wildlife economy, as the lives of lions are not only reduced to trophies for international hunters but have become substitutes for tiger bones in the production and trade of traditional medicine. While many industry actors condemn canned hunting, such as Safari Club International, nature remains produced through an economic lens and anchored in colonial representations of Africa, settler mythology, and 
neo-Malthusian discourses that naturalize the notion that the only way to save wildlife is through killing it.

\section{Methods}

Data collection and findings occurred between 2015 and 2019 in South Africa (Northwest, Mpumalanga, Limpopo, and Gauteng provinces), Washington DC, Las Vegas, NV and Harrisburg, PA. I used an assortment of qualitative methods that included discourse analysis, participatory observations, and semi-structured interviews. The latter included the following participants: 1) state government (Department of Environmental Affairs, South Africa National Biodiversity Institute, USFW); 2) Non governmental conservation organizations (Endangered Wildlife Trust and TRAFFIC); 3) Wildlife ranching and hunting organizations (Professional Hunters Association of South Africa, Custodians of Professional Hunting and Conservation, South Africa Predators Association, Confederation of Hunting Associations of South Africa; and 4) wildlife ranching and trophy hunting industry actors (taxidermists, wildlife ranchers, captive lion breeders (1), game farmers, game managers, professional hunters, international hunters, and veterinarians).

Interviews (50) were structured according to the specific role of each research participant. For example, interview questions for state actors differed greatly from wildlife ranchers. As for ranchers, as well as trophy hunters, my initial questions sought to understand their background and history, motivations and views of trophy hunting, perceptions of their role in conservation, and what they perceived to be the challenges and greatest threats to the industry. After establishing a baseline, I used the flexibility of semi-structured interviews to elicit deeper responses that covered issues such as land expropriation without compensation and rural development. At the end of each interview I solicited research participants to make recommendations with regards to who they thought I should meet and interview. In some cases research participants directly contacted and set up future interviews for me. Using the snowball technique allowed me to gain entry onto many game farms where I was able to collect additional data.

Furthermore, I draw on participatory observations of international hunting safari conventions in Las Vegas (2), one lobbying event in DC, wildlife auctions (2), small and large-scale game farms (11), wildlife breeding operations (4), game captures (2), and one game reserve. Individual interviewees oftentimes played any number of roles within the industry: landowner, professional hunter, safari outfitter, and taxidermist. At the same time, overlap occurs with regards to game farms, as some provide ecotourism trophy hunting safaris, while others also include wildlife breeding and taxidermic services. I refer to this particular overlap as wildlife ranches throughout the dissertation. Participatory and non-participatory observations for this project took place primarily in the Northwest and Limpopo provinces. I selected these regions based on time, accessibility, trophy hunting popularity, and density of farms, ranches, and auctions. The collection of participatory observations, personal and informal communications, and the 50 semi-structured interviews I was able to illicit, inform the basis of the proceeding analysis. 
Interviews took place in the homes or business offices of game ranchers, farmers, and managers. Less structured interviews, for example, took place at times in the cab of 4 wheel drive vehicles while surveying and learning about the landscape and wildlife management, or while accompanying hunting safaris. State interviews occurred at office buildings, cafes, and places such as the Botanical Gardens in the City of Tshwane (formerly Pretoria). I used a digital recorder to interview research participants to capture subtleties of communication such as pauses, inflection, emphasis, and moments of silence, which I immediately uploaded and transcribed into Word for accuracy. These transcriptions were later uploaded into Nvivo, which I then used to identify and analyze specific quotes and re-occurring language and themes. I arranged these discursive themes according to nodes, such as production of nature, commodification, fetishization, sustainable use, conservation, and value making. Using this software revealed the frequency of specific words and terminology and how they are used according to different roles in the wildlife economy. New categories of analysis emerged from this initial inquiry, such as wildlife management risks and internal industry conflicts, which further problematized the ecological, economic and social aspects of nature production.

Using a digital camera I recorded and photographed industry practices, social relations, landscapes, and nonhuman behaviors present between and at all observation sites. These observations presented greater insight into the ways nature is commodified. For example, I recorded how auctioneers at auctions spoke to the bloodlines and genetics of specific species to encourage bidding and sales. Additionally, I was able to document the wildlife industry's struggle to integrate black South Africans in wildlife ranching and the residual racial and asymmetrical power relations of apartheid that continue to permeate these semi-wild spaces. Central to my findings are in-depth textual analyses of the following: art; imagery; taxidermy; use of social media; online newsletters and magazines; hunting websites; emails; ballots; videos; online hunting testimonials; speeches at luncheons; presentations and information seminars; ribbon cutting ceremonies; convention auctions; and state documents, policies, and reports.

Preliminary data collection began in Las Vegas, NV at Safari Club International's Annual Hunter's Convention in 2016, where I attended presentations and interviewed safari outfitters, professional hunters, and landowners about the phenomena of trophy hunting. I soon discovered the aphorism, "If it pays, it stays," and began to understand the ways this economic logic served as the philosophical foundation of wildlife management in South Africa. It stimulated new lines of inquiry: What does this logic portend for nonhumans? What is the relationship between this logic and trophy hunting? How does it relate to private land ownership? Who are the actors that diffuse this way of thinking? What types of strategies are necessary to maintain trophy hunting? Who profits? What types of alliances are there? Does trophy hunting ameliorate the uneven, fragmented landscape of South Africa, or reproduce it? Why or why not? These were some of the questions I had in mind when I flew to South Africa in the summer of 2018. 


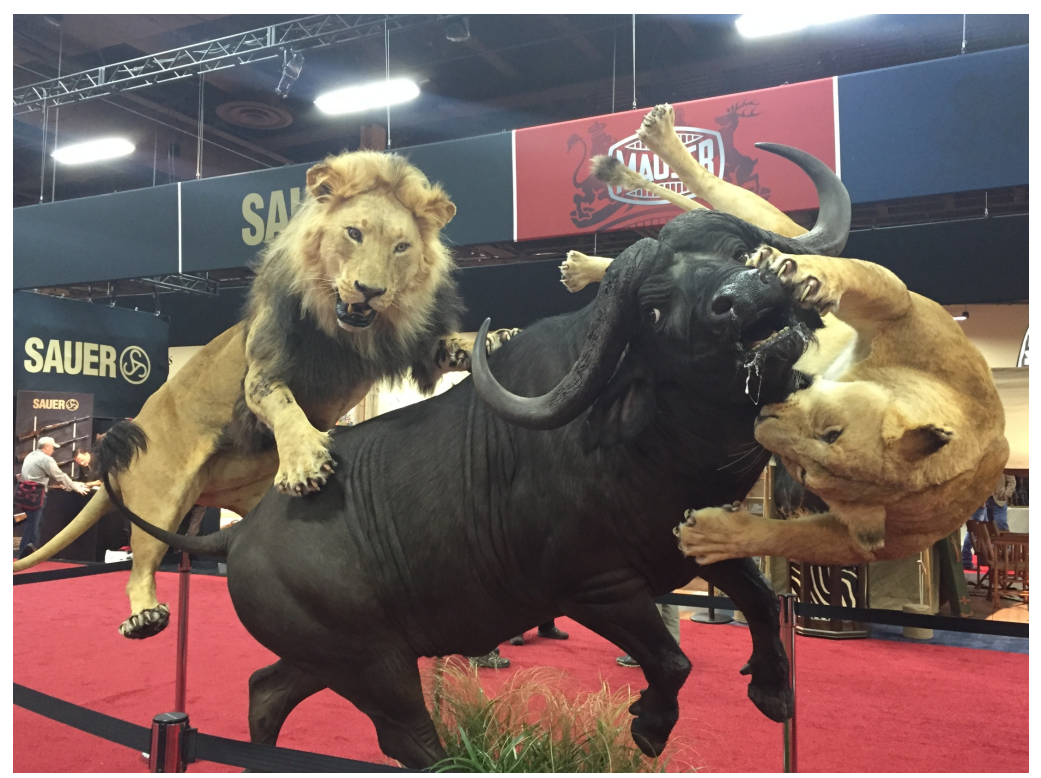

\title{
Chapter 1
}

\section{An Analysis of Right Wing Political Ecologies at Safari Club International's Annual Hunter's Convention}

\begin{abstract}
The international trophy hunting industry argues that killing animals to save them is necessary to the protection and conservation of threatened, vulnerable, or endangered wildlife. This discourse depends on a crisis of international biodiversity and is set within a neoliberalized green economy that entrenches and expands upon the ongoing violent nexus of colonialism, capitalism, and conservation (Brockington et al., 2008). While the critical analysis of neoliberal conservation is well rehearsed within the growing field of political ecology, this paper coins a new term, right wing political ecologies, which defines the ways in which right-wing ideologies, identities, discourses, and cultural myths interface with and co-opt market logics and mainstream environmental discourses. Using the carefully orchestrated spectacle of nature at Safari Club International's Annual Hunter's Convention at Mandalay Bay's Conventional Center in Las Vegas as a site for qualitative interrogation, this paper reveals the trophy hunting industry's specific use of colonial epistemologies, myths, imagery, and representations of nature and "Africa" to legitimize and intensify the commodification and privatization of non-humans for sport. Ever present on the consumer floor are colonial discourses that hinge upon the celebration and development of masculinity, militarism, nationalism, paternalism, speciesm, and a collective sense of hunting humanitarianism.
\end{abstract}

"Neoliberal conservation, a product of capitalism, acts on its part to construct realities devoid of contradiction, to produce an image of consensus, inclusivity of all stakeholders, that everyone is "on board." - Bram Buscher, 2013 - Transforming the Frontier 
"The national bourgeoisie will be greatly helped on its way towards decadence by the Western bourgeoisies, who come to it as tourists avid for the exotic, for big-game hunting and for casinos.

The national bourgeoisie organizes centers of rest and relaxation and pleasure resorts to meet the wishes of the Western bourgeoisie. Such activity is given the name of tourism, and for the occasion will be built up as a national industry..." - Frantz Fanon, 1963 - Wretched of the Earth

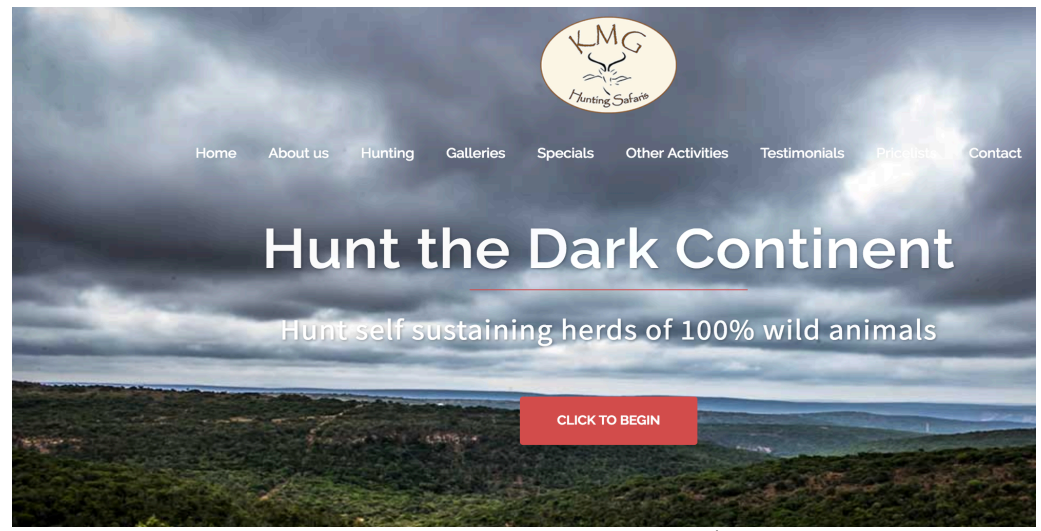

(KMG, retrieved 2018) $)^{1}$

\section{Introduction}

In response to the DC Circuit Court's opinion in Safari Club International et. al vs. Zinke et. al, the US Fish and Wildlife Service withdrew a number of previous ESA (Endangered Species Act,1973) enhancement and non-detrimental CITES (Convention on International Trade of Endangered Species of Wild Fauna and Flora) findings affecting elephants in Zimbabwe, Zambia, and Tanzania, and lions and bontebok in South Africa, among others (US Department of the Interior Memorandum, 2018). In other words, trophy importation applications will be reviewed and permits will be granted or denied on a "case by case" basis (US Department of the Interior Memorandum, 2018). The larger meaning here, and more relevant to this paper, is that SCI opposes and seeks to remove any legislation when it negatively impacts their ability and perceived right to hunt and import wildlife skins, skulls, horns, and tusks.

The 2016 Hunter's proxy ballot of Safari Club International (SCI) - Political Action Committee asked the following question: "Do you believe that our American heritage of hunting, and our rights to travel overseas to hunt and import game trophies are worth fighting for? " (Proxy ballot received by post, January 2016). The phrasing of the question assumes that hunting abroad is a right, much like the $2^{\text {nd }}$ amendment, which protects the right to bear arms. The discourse purposely conflates these rights as one and the same, which to gun-owning Americans is sacrosanct. A recent SCI "Member Alert" sent via email advocating for current SCI president Paul Babaz to continue his service on the NRA Board of Directors echoes this discourse:

\footnotetext{
${ }^{1}$ http://huntsafaris.co.za: "Hunt the Dark Continent" is commonly found on safari company websites as a way to stimulate hunter interest.
} 
"The need to align ourselves with like-minded groups such as the NRA only helps strengthen our fight against both the radical anti-hunting groups and those who would rob us of our Second Amendment rights. Hunting and firearms are tightly woven in the fabric of America and what affects one will surely affect the other. Paul now has an additional year of experience in how desperate the antis are in depriving us of our rights. (SCI First for Hunters newsletter, 2019)

The conflation of rights when used in conjunction with the invocation of American mythology can be very effective, particularly when situated in discourses that perpetuate the fear of losing religious and cultural traditions to "radical anti-hunting groups." The greater the perceived crisis of losing a cultural war to radicals, the greater their steadfastness. Through this tenacity emerges a politics of difference, a crude us vs. them discourse couched in a cultural war of righteousness against a demonic Left. Trophy hunters invoke the words and life of Teddy Roosevelt in support of their conservation ethos. To the indoctrinated, "he was both father and protector of modern conservation in defense of the rights of the people, in the love and conservation of nature and of the best

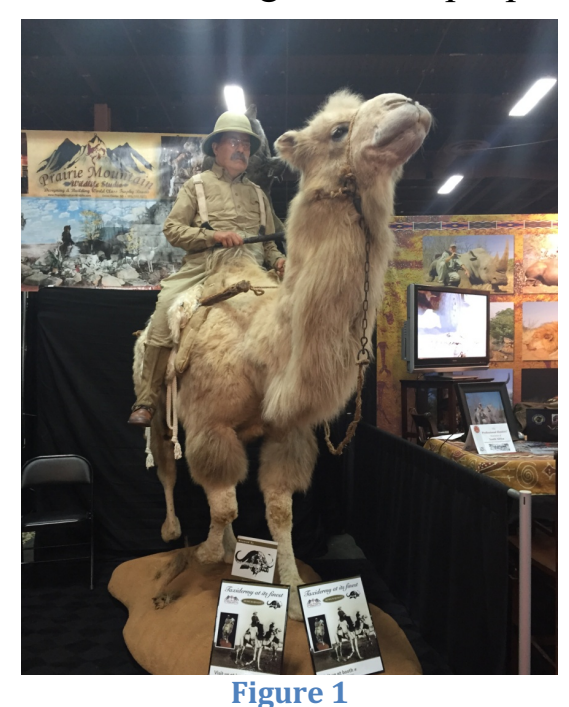
in life and in man" (Haraway, 1984). His hagiography remains an ever-present symbol of American values: democracy, Christianity, adventure, commerce, and science (Haraway, 1984). His famous quote, "Aggressive fighting for the right is the noblest sport the world affords... if I must choose between righteousness and peace, I choose righteousness" (Haraway, 1984), continues to strengthen trophy hunters conviction against antitrophy hunters. In his book, The Winning of the West (1953), Roosevelt portrayed the chivalrous, selfreliant hunter as the central hero in American history, writing that though American backwoodsmen were farmers as well as hunters, "a race of peaceful, unwarlike farmers would have been helpless before such foes as the red Indians" (Herman, 2003). In the

late $19^{\text {th }}$ and early $20^{\text {th }}$ century, hunting instilled a rugged individualism and "self-reliance instrumental to taming the wild frontiers while the sport of trophy hunting marked an ethnic distinction from which to claim cultural superiority" (Herman, 2003). Indeed, this very approach to hunting helps us understand how "indignation of the hunting community against the killing of animals sharpens their identity, acts to buttress the legitimacy of its practices" (Cohen, 2014). It's no surprise that Roosevelt's presence permeates the Safari Club International's (SCI) Annual Hunter's Convention showroom floor. (Figure 1)

At Safari Club International's Annual Hunter's Convention in Las Vegas (2018), I attended a SCI-NRA luncheon to listen to Eva Shockey, daughter to world-renowned hunter, TV producer and star, Jim Shockey. Before she could be properly introduced, attendees pledged their allegiance to the flag and listened to the Star Spangled Banner. 
The national anthem was sung alongside a large video screen flashing the following imagery: Mt. Rushmore; WWII soldiers planting the US flag at Iwo Jima; the Washington Memorial; WWII Memorial, Lincoln Memorial at night, US soldiers posing together in a photo taken in Iraq; fireworks; US soldiers in silhouette juxtaposed to an American flag; a farmer; and the Statue of Liberty. This patriotic spectacle was meant to inspire a deeper admiration, love and pride for military, country, and a heritage of fighting for what's just and right.

The relationship between hunting and heritage became clearer with the following speaker, Chris Cox, who was introduced as "one of the leading voices to protect our freedom to bear arms." Cox is executive director of the National Rifle Association Institute for Legislative Action (NRA-ILA), and chairs President Trump's $2^{\text {nd }}$ Amendment Coalition. He is also president of the NRA's Political Victory Fund and was given the responsibility of introducing the honorary speaker, Eva Shockey. He began his introductory speech with a story about meeting a woman as he was waiting in line at a CVS while clad in hunter's camouflage. He had just been out on an unsuccessful duck hunt but was generally feeling pretty good about things, for hunting is every bit as much if not more about being out in nature than the act of killing, which invokes the famous Ortega and Gasset quote: "One does not hunt in order to kill; on the contrary, one kills to have hunted" (Kheel, 1996). [Many hunters told me the same, that the killing is only 10\% of the hunt; the other $90 \%$ is being with friends, out in nature, escaping the frenzied pace of everyday urban life, which is perhaps morally problematic because it supposes that one's idea of a good time is actively seeking to take the life of another animal.] Cox recounted how the woman proudly boasted she was a vegan, which prompted him to ask if she supported wildlife conservation, if she "puts her money where her mouth is." Aside from the suspicious nature of this anecdote, this is a common retort heard throughout the trophy hunting world, as sportsmen spend millions of dollars annually on hunting permits, license fees, sporting equipment taxes, etc. (e.g., Pittman Robertson Act). Hunters argue that they are the true conservationists, as their money goes towards habitat restoration, natural resource management, and environmental education programs.

Without their money there wouldn't be national forests or a national park system, which they owe to Theodore Roosevelt, whose naturalist ethos helped birth the North American Model (NAM) for conservation. Cox proudly shares this with her, to which he says she has no response. He frames her speechlessness as yet another ignorant "anti", one easily influenced by "the flow of \$18 million dollars coming from George Soros" and the formidable and well-organized attack on "everything we stand for" in an attempt to eliminate "everything we believe in." This refrain, the idea of a leftist and overly emotional anti-hunting community out to eradicate American heritage and tradition, is often expressed in the Safari Times by President Paul Babaz, CEO Rick Parsons, and Washington DC Correspondent Patrick O'Malley. Heads in the crowd nod in agreement. He then states emphatically that pro-hunters need to get the message out "unapologetically," which is what makes Eva Shockey so special, as she's proud of her contributions to conservation and "unafraid to tell the truth" (Cox, 2019). Here Cox successfully performs culture and identity incisively through staged discourses of difference and righteous indignation. He receives loud audience approval.

Cox then shares a three-minute video about Eva Shockey, which highlights meanspirited leftists on social media unfairly attacking her for hunting a black bear in North 
Carolina. After posting photos on her Facebook page of a hunt that was according to Eva Shockey, "the biggest bear of my life," she received thousands of death threats.

Following the video, Shockey eventually walks onto the stage. She continues in a similar vein, reading off some of the horrible social media comments, a mixture of disingenuous appall and incredulity at the language that the "antis" use, as well as their blatantly obvious misunderstandings about how conservation works.

"To me it was a local hunt, it wasn't an elephant hunt, a rhino hunt, or a lion hunt, all the hunts that seem to be causing all the controversy and you'd expect the backlash. This was a rural hunt in a rural part of northeastern North Carolina. It was an area where farmer crops and farming machinery was being decimated by overpopulation and these farmers were crying out for help and I thought I was there giving them the help that they were looking for. In my mind it was about raising funds for wildlife management... and putting money where our mouths are..." (Shockey, 2019)

If there is indeed an overpopulation problem at the root of human and nonhuman conflict, then the religious right does nothing to mitigate it. While utilizing the theory of overpopulation to kill may be cynically selective and cause for concern, the theory and revitalization (neo-Malthusian) of it is heard in popular conservation circles that are not distinctly right wing. Co-optation of liberal elements in conservation such as this, in addition to the most obvious and rehearsed ontologies dichotomizing nature and society, remain at the root of nature conservation.

The anecdote above reveals an integral component to right wing political ecologies, which simultaneously carves out discourses of cultural difference and identity, false victimhood, and savior: Shockey's comment that farmers were "crying out for help" implies that hunters are saviors in this ongoing conflict between wildlife and humans. Simultaneously she's both hero and victim. If this is the case, then condemnation and critique of hunting becomes susceptible to being framed as heartless. It's a mentality that says 'how could you not help others in need? It's the least one can do!' Viewed uncritically, without her presence farmers will die from bear attacks and nature will be left to unfettered human development and environmental degradation because there are simply no other means to finance conservation or solve overpopulation. Hunting is the only way.

She goes on to act shocked by the outrage on social media: “...5,000 people on that given day were sitting at their computers wanting me to die. Some suggested that I should be raped. Some suggested my mom should die." She reads off a few of the threatening and disconcerting comments. They reveal disgust and revulsion, but to Eva it's all unwarranted and symptomatic of misinformation coming from the left side of the political aisle.

"This is disgraceful. Let's hope that someone hunts her so they have a trophy."

"I'd love to have the picture in reverse. Her slumped lifeless."

"I sincerely hope you get shot in the head in a hunting accident."

"You're a psychopath and deserve a long and painful death." 
"You are a stupid, retarded b-word. I hope you reproduce and your baby gets hunted down."

In response to an anti-hunter who said, "Kill that worthless little dog you have instead of the bear, " she stated the following:

"Apparently hunting a bear, and eating and donating all of the meat and giving money towards conservation is a bad thing, but killing my puppy is okay."

The social media comment highlights how wildlife is revered, particularly charismatic megafauna. Interviews revealed that many hunters believe that non-hunters generally have a Disneyfied understanding of wildlife, one that's informed by the Lion King and other media misrepresenting nature as cuddly and cute rather than cruel and complex. Operating from these broad perceptions, in conjunction with the above online outrage, Shockey and other trophy hunting advocates believe sustained critique from the radical Left is over-sentimental and ignorant. In response to social media attacks, Shockey redirected her victimhood into sharing her love of hunting on television news programs and selling T-shirts that would raise money for pro-hunting organizations to combat anti-hunting campaigns. In an interview with Fox and Friends, she said the following in reference to a rising human and bear population:

“...They're both rising really fast and obviously we're not going to get rid of the humans so at that point you have no choice, it's human nature, you need to make room for the humans to live there so you have to keep the bear population in check...if we won't do then the farmers will do it and it won't be as nice as the hunters." https://video.foxnews.com/v/3894995072001/\#sp=show-clips, retrieved March 2018)

Killing nonhumans to make space for a growing human population is not human nature. For SCI members, hunting is the panacea for reducing human-animal conflict; it is the only solution to a perceived human overpopulation crisis as opposed to strategizing how to live with nonhumans. Killing a nonhuman, it can be argued, particularly with respect to an older animal whose teeth are so worn down he/she can no longer eat, can be viewed as compassionate in lieu of the nonhuman's imminent suffering and diminished quality of life. This type of suffering is terrible, and so a trophy hunter can argue that hunting is the most compassionate alternative. Liberals don't hunt, but surely they don't want to be killed by a bear or have to kill a bear. From this point of view hunters are simply protecting their communities and doing a job that most are too squeamish or unwilling to do. This is why trophy hunters often use masculine language such as strong, courageous, heroic, logical, and scientific when describing their contributions to conservation. On the other hand, they portray their liberal opponents in very feminine language, using words such as emotional and sentimental to discredit critique and activism.

The above quote also speaks to sustainable utilization discourses that operate not only under a human/nonhuman hierarchy, but an ecocentrist (Cohen, 2014) one as well. 
Ecocentrism "favors the greater good of biotic communities over individual beings, and is hence prepared to sacrifice individual animal lives for preserving biotic equilibrium" (Cohen, 2014). In a promotion video called $A$ Conservationist Cry by PHASA (2018), one South African game farmer stated the following:

"A few of these animals have to die to support the others. They have to. If we hope to preserve the wildlife we will have to continue to hunt. There is just absolutely no other way."

Underpinning interventionist logic is that humans are separate from nature and thus humans must act to restore boundaries, safety, and ecological balance. I later discovered what Snijders (2019) refers to as the ability of hunters to maintain two contradictory narratives, one that clearly separates humans from nature, but one that also conflates the two. The purpose of conflation is to set humans and nonhumans on equal terms, so that hunting can be framed as fair despite the technological advantages that modern hunters have (Snijders, 2019). In this encounter, humans become nonhuman animal, and nonhumans become more human. It's a zoological-anthropomorphic (Snijders, 2019) discursive dance that greens and massages a less than benign violence. The distinction between humans and their technological equipment vs. nonhumans that are unaware that they are game in a sport remain clear. The game is nonconsensual, rooted in uneven power relations. "The rules require the animal's death... and the outcome is predetermined" (Kheel, 1996). But by complying with the rules of fair chase, sport hunters feel they are able to express their animal instincts while also demonstrating their superiority to the animal world (Kheel, 1996).

Ryan Zinke, former Secretary of the Department of the Interior (DOI) who recently resigned in disgrace against a backdrop of imminent criminal investigations, formed a special advisory called the International Wildlife Conservation Council (IWCC). This committee is comprised of well-connected political donors, and trophy hunting, firearm, and animal trade representatives like Safari Club International and the National Rifle Association. The IWCC was put together with the intention of reversing, removing, or amending environmental and wildlife protections such as the Endangered Species Act (1973) and Antiquities Act (1906). In August 2018, a number of conservation and wildlife protection organizations filed a lawsuit in the United States District Court for the Southern District of New York against the DOI and US Fish and Wildlife Services (USFWS). According to the National Resource Defense Council (NRDC), Center for Biological Diversity (CBD), Humane Society of the United States (HSUS), and Humane Society International (HSI), this special council is in clear violation of the Federal Advisory Committee Act (1972), which was enacted to "curb the executive branch's reliance on superfluous and secretive advisory committees" (www.biologicaldiversity.org, retrieved January 2019). The trophy hunting industry perceives these lawsuits, and critique in general, as "unreasonable and unfair" attacks that threaten their way of life.

The materialization of the IWCC is both a response to ongoing criticism and affirmation of its necessity. Trophy hunter actions are portrayed negatively on social media (Eva Shockey, Cecil the Lion, Extreme Huntress, Sky, etc.), as non-hunters presume that trophy hunters masquerade as conservationists that are primarily motivated by a masculine urge to conquer and kill. American trophy hunters have been unable to 
import lion and rhino trophies according to both ESA and CITES regulation, though recently a trophy hunter applied to the USFW and was granted permission to import the horns, hide, and skull of a black rhino he shot in Namibia for $\$ 400,000$. According to the 2016 National Survey of Fishing, Hunting, and Wildlife-Associated Recreation, hunters are disconcertingly dwindling in number (USFW, 2016). Christian culture is under multicultural assault. And their rights to bear arms are slipping away. Hunting culture and America are under perceived attack, and so the industry must adapt and shift accordingly. From this crisis framework emerges a series of self-preservation techniques, strategies, and discourses that the hunting community uses to stimulate and legitimize its own reproduction.

My analysis draws on postcolonial critique of taken-for-granted Western epistemologies and ideologies governing conservation (Neumann, 1998; 2004; Said, 1978); the production and accumulation of nature spectacles and imagery (Debord, 2012; Igoe et al., 2010; Buscher et al., 2012); militarized approaches to conservation (Lundstrom, 2014); lively commodities (Haraway, 2013; Collard \& Dempsey, 2013; Barua, 2017); and consensus-making discourses found at international conventions (Corson \& MacDonald, 2010; Craggs \& Mahony, 2014; Buscher et al., 2012). Safari Club International's Annual Hunter's Convention reveals a spectacle of nature promoting acts of "humanitarian" (Mostafanezhad, 2013) and "nature-saving" consumption that green wash (Fairhead et al., 2012) the contradictions of killing (Ramutsindela and Buscher, 2015) and fetishize capitalist production (Marx, 2015; Harvey, 2018; Buscher et al., 2012).

The major contributions of this paper are that it brings conservative, right wing politics into conversation with market-based conservation. This paper endeavors to deepen our understanding of how trophy hunters appeal to cultural identity and mythologies of trophy hunting (Simon, 2016), which ultimately strengthens the symbolic and material links between colonialism and the hegemon of conservation. In the pages below I continue to advance the theme of 'politics of difference', in addition to how colonial ways of thinking, and African landscapes and wildlife imagery are utilized to fetishize and greenwash the production and killing of nature. This paper ultimately demonstrates the methodological prowess of conventions as sites for gleaning greater insight into the links between the discursive and the material. Such sites have seen limited engagement in political ecology literature, though Corson and MacDonald (2010) and Buscher et al. (2012) do provide us with significant insight.

\section{Methods and Data Collection}

For the past five years (2015-2019) I have used a number of ethnographic and qualitative techniques with a focus on convention and conference sites (Craggs and Mahony, 2014; Perez, 2017; Corson and MacDonald, 2012) and critical discourse analysis (Fairclough, 2013; Said, 1978, Sharp, 2008) to illuminate the relational processes of consensus- and knowledge-making, cultural identity, colonial epistemologies and representations, and the neoliberalization of nature (Buscher et al., 2013). Perez (2017: 83) cites Craggs and Mahoney (2014) who define conferences as "periodic or one-off gatherings of people - often professionals, experts and those in positions of power - drawn from diverse places and organizations, with aims of producing knowledge or agreement on particular topics." Corson and Macdonald (2012: 
8) understand conventions as "sites that structure emergent green market opportunities and practices." Fairclough (2013) posits "there are no social events or practices without representations, construals, conceptualizations or theories of these events and practices...that social realities have a reflexive character... and thus objects of critical social analysis are 'material-semiotic' (Jessop, 2004) and 'dialectical' (Fairclough, 2013)."

Guided by this framework I attended Safari Club International's Annual Hunter's Convention in the winters of 2016 and 2018 in Las Vegas, NV. While there I used participatory observations and semi-structured interviews to evaluate the phenomenon of trophy hunting. My analysis begins more broadly with understanding the relationship between US trophy hunters, including specifically Safari Club International, and sustainable use conservation in sub-Saharan Africa. As this paper is part of a larger research project examining international trophy hunting and its relationship with wildlife ranching in South Africa's green economy, I then scaled down to the national level and targeted South African stakeholders. South Africa remains the most popular hunting destination in Africa for Americans. Between 2005 and 2014 South Africa represented $32 \%$ of animals imported into the US (HSUS, 2016). South Africa, like the United States, was a settler colony and subsequently shares a number of cultural, historical and political features that help broaden the interpretive scope of right wing political ecologies, which I define as the diffusion of right-wing ideologies, identities, discourses, and cultural myths that interface with market logics and mainstream environmental discourses.

Geographers have used participant observation to gain a deeper understanding of the places and people they are researching (Laurier, 2000). Participatory observations for this paper included surveying the large-scale consumer floor and attending ribbon-cutting ceremonies, luncheons hosted by the National Rifle Association, and seminars. I therefore observed the relationship between hunting organizations, NGOs, safari operators, game farm owners, and international trophy hunters, and how the product of trophy hunting is marketed and adapted to suit prospective hunter expectations. It was important to understand the ways in which nonhuman nature is represented, the many ways in which nature is depicted as both feminine and wild, and simultaneously under attack and ready to attack.

At the convention I used an iPhone video recorder to capture auctions, luncheons, opening ceremonies, and general convention activities such as social interactions between prospective hunters and safari outfitters, and hunters sizing up rifles on their shoulders for purchase. For interviews I used a digital recorder to capture nuance (pauses, inflection, periods of silence) in interviewee voice and for immediate transcription into Word document form. I uploaded these transcriptions into Nvivo, which I then used to identify and analyze themes. I targeted and highlighted specific quotes or use of language that represented specific themes. I coded these themes into nodes, such as masculinity, representations of Africa, threats to industry, paternalism, cultural identity, and heroism. I distilled these themes even further. For example, through analysis of representations of Africa I could separate them into more specific categories such as colonial, dangerous, passive, and Othering (Said, 1978), which overlapped with other categories and stimulated new inquiries. I identified and analyzed the cultural identity theme, separating out patriotism and nationalism, victimization, tradition, and mythology. I also entered videos, images, email correspondence, Safari Times newsletters (monthly), online 
magazines (WRSA and SCI), text from social media (Facebook and Twitter), and Internet searches of hunting safari websites and news articles into Nvivo. I organized these as well into relevant thematic nodes. Once all data was compiled I could determine the most salient themes, commonly used words (i.e., greenies, sustainable use, fair chase), images (black rural communities grateful for the meat they've received or smiling hunters positioned behind their dead trophy), phrases ("if it pays, it stays," or "hunters put their money where their mouths are, trophy hunters are conservationists, let Africa decide how to use their natural resources, etc.) and common arguments advocating trophy hunting. To ensure a consistent range of topics was covered, I used semi-structured interviews, which allowed a flexible approach to questioning and gathering opinions and behaviors in the informants' own words (Longhurst, 2003). The use of semi-structured interviews is a strategic tool that "allows the views of different stakeholders to be put into indirect dialogue with each other to produce more nuanced conversations" (Cousins et al., 2008). Qualitative interviews at Safari Club International's Annual Hunter's Convention ( $\mathrm{n}=22)$ addressed a combination of landowning game farmers, hunters, safari outfitters, South African NGOs (Professional Hunters Association of South Africa, Wildlife Ranching South Africa, Predator's Breeding Association of South Africa), and US conservation agencies (USFW). These interviews focused on the following: (i) motivations and perceptions of hunting; (ii) land use; (iii) marketing strategies; (iv) conservation; (v) the future of trophy hunting and game farms in relation to current politics, policies, and environmental threats; and (vi) land owner relations with adjacent communities and their responsibility towards rural transformation (the amelioration of uneven development). Using person-to-person, semi-structured interviews allowed me to delve more closely into the "life histories" (Jackson and Russell, 2010) of relevant stakeholders such as professional and international

hunters, game farmers in southern Africa, and safari outfitters.

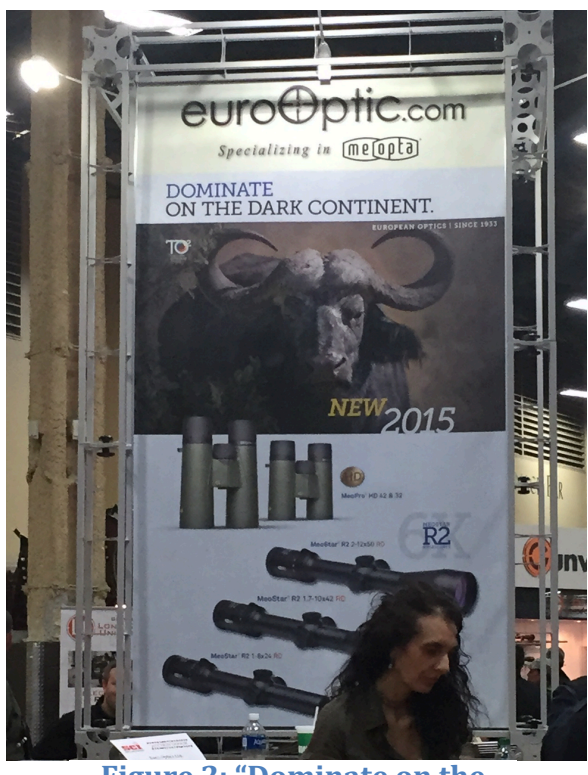

Figure 2: "Dominate on the Dark Continent"

Critical conservation geographers can better explore the alliances and new corporate bedfellows of conservation through attending international hunting conventions. For example, they can better ascertain the ways in which value is created, for "green valuations, circulations and commodifications, along with associated business and market logics, are being shaped in global flora and fauna, media and actor-networks that are sometimes virtual and often dislocated and distanced from the places they govern" (Fairhead et al., 2012). Safari Club International's Annual Hunter's Convention provides such a "dislocated" place in which animal lives are mediated through the post-colonial relations of capital.

Background Literature: A "post” colonial gaze

"'Hunt Real Africa' is our credo. Our primary aim is to make this dream as real and as authentic 
as is humanly possible." - (Bosbok African Safaris, 2019)

"The thrill of hunting dangerous and plains game is what has drawn the HARD CORE HUNTER (emphasis in original) to Africa for over a century. Follow their footsteps to the "Dark Continent" where HFS will help you make your dreams a reality." (Huntley Ferreira Safari's, 2019)

Frontiers of hunting, livestock management, and resource extraction were all very powerful symbols for new nations and masculinities (Beinart and Coates, 2002). Historically, the imperative to protect nature became a strong part of white settlers' identity, and one that helped fulfill the colonial mission (MacKenzie, 1997; Neumann 1998) of capitalist accumulation through alienating people from their labor (Marx, 2015). Roderick Neumann stated "control over nature, either for aesthetic consumption or for production, must be recognized as an integral part of the geography and history of empire" (Brooks et al., 2011). Racist imaginings of the Other (Said, 1978) amplified ahistorical and apolitical simplifications of environmental degradation that pinned blame on indigenous livelihood production systems.

Underpinning colonial conservation policies in Africa was the belief that Africans did not know how to be 'stewards' of their land, that they were "backward, superstitious, immoral heathens," too ignorant to appreciate the aesthetics of nature because they were considered "not altogether too far removed from the wild" (Sharp, 2008). Jan Smuts, the central figure in South African politics in the first half of the twentieth century, asserted, "By temperament (Africans) have not much initiative, and if left to themselves and their own tribal routine they do not respond very well to the stimulus for progress"

(MacDonald, 2006). Reducing indigenous people to less than human status (Agamben, 1998) facilitated the process of rendering them no longer visible on the landscape. The geographic imagining of Africa as a peopleless, wild continent served to justify both the conquering and exploitation of natural resources as well as desires to protect nature that emerged in the second half of the $19^{\text {th }}$ century (Ramutsindela et al., 2013; Grove, 1997; Beinart, 2000). The colonial project constructed the notion that African nature was excessive, and that there were "too few Africans", with the "understanding that natural resource extraction and the accumulation of greater wealth depended upon available labor" (Broch-Due and Schroeder, 2000).

State policies by the mid- $20^{\text {th }}$ century tantalized tourists from afar by promising encounters with "wild nature and an unspoilt African landscape" (Brooks et al., 2011). Use of film, literature, and adventure stories documented and written by white naturalists, conservationists, explorers, and documentarians transported armchair and adventureseeking Westerners into an untamed wilderness whose natural aesthetic, biodiversity, and charismatic megafauna begged greater regulatory management and preservationist controls. Nature documentaries and television shows, such as On Safari, portrayed Africa as a pristine wilderness endangered by the inevitable arrival of African independence (Mitman, 2012). The use of popular media reinforced racist imaginings of the Other and directly impacted environmental governance in the "post"-colonial era.

The "post"-colonial nostalgic vision sees land as deficient, always on the brink of disappearing in the haze of modernization, impoverishment, and overpopulation (BrockDue and Schroeder, 2000). The belief that natural resources are being used unsustainably provided rationale for state and foreign intervention, otherwise known as development (Brock-Due and Schroeder, 2000). In essence, the "post"-colonial development project 
has increased classification, categorization, privatization, enclosure, and zonation of the "global commons," and championed those who adhere to its global norms, while others, generally the poor, have been castigated, demonized, and must conform to the rational march of modernism (Schroeder, 1999).

According to Buscher et al. 2012, the conservation of nature is about finding new arenas for markets to operate in and thus to ultimately expand the circulation of capital. "Capitalism separates, splits, and - because in principle everything can be bought and or sold-alienates and estranges" (Buscher et al., 2012; Kovel, 2002). Environmental governance is based on this divisive market-based logic. In much of Africa, the management of wildlife is contained within private enclosures. In South Africa specifically, these enclosures keep poor people out, and more generally, those who have been marginalized in a long history of colonialism and apartheid (Kamuti, 2014). The only people allowed onto these private reserves are wealthy trophy hunters and ecotourists, conservation scientists, veterinarians, and game capture teams. These enclosures, which now number 10,000 and which cover an estimated 21 million hectares of land (PHASA, 2016), are justified as a necessary means to help South Africa meet its national and international conservation biodiversity protection initiatives and developmental goals.

In Towards a Synthesized Critique, Buscher et al. 2012 suggest that the neoliberal conservation critique might be synthesized into three main points: 1) the stimulation and concealment of contradictions; 2) appropriation and misrepresentation; and 3) the disciplining of dissent. The first of the three points underscores how the contradiction arises where profit motives are the driving force in relationships between people and natures: "the demand for profit will tend to trump positive social and environmental outcomes wherever it is at odds with them" (Buscher et al., 2012). "Neoliberal conservation's core axiom is that in order for natures to be saved, acts of nature saving must be imbued with profit potential or else there is little incentive for rational actors to pursue it" (Buscher et al., 2012).

The second critique of neoliberal conservation, misrepresentation and appropriation, fits well within the "spectacle of nature" (Igoe et al., 2010) found at the hunting convention. Debord defined spectacle as "the mediation of social relationships between human beings by image." These images act in service to capitalist ideology, and reflect a "bourgeois vision of the world" (Briziarelli and Armano, 2017) that "produce natures that appear to transcend capitalist contradiction" (Buscher et al., 2012). As member of the Situationalist International, an avant garde group following in the tradition of Marx to challenge an exploitative capitalist system hinged on the alienation of labor (Matthews, 2005), Debord sought to re-situate people in their own history and environment, therefore repositioning them outside the Spectacle" (Briziarelli and Armano, 2017). As will be discussed in the pages below, the spectacle of wildlife at SCI's hunting convention obfuscates the real relationship between nature and capital. Selling nature becomes normalized, the ever presence of wildness excites and obscures the violence and environmental degradation in which capital depends.

The third critique speaks directly to the assemblage of corporate CEOs, professionals, NGO leaders, merchants, and military ambassadors and retired special operations marines, resemble what Gramsci (1971) referred to as an historic bloc, which is a moment in which diverse groups who "share particular interests come together to 
form a dominant class, and their ideas come to dominate the ways in which other people consent to see - and are able to talk about - the world" (Buscher et al., 2012). This critique applies to how the hegemon of international conservation has been capitalized upon by the trophy hunting industry.

\section{Data and Discussion: The nature that comes with freedom}

Safari Club International's Annual Hunter's Convention in 2016 began with the ceremonial cutting of the ribbon, which was made by the widow of Chris Kyle, Taya Kyle, whose late husband was famously depicted as a hero killing "savages" in the film American Sniper. In her short speech, she stated that she thought a lot about protecting American freedom, and ended by remarking that her husband was "passionate about the peace that comes with hunting." While it's not entirely clear if these sentiments excluded

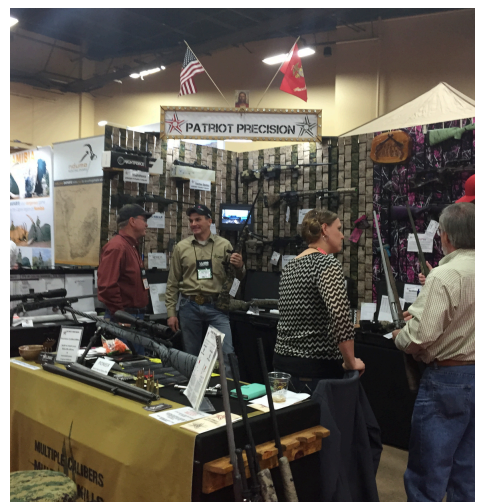
the hunting of human 'savages' in places like Iraq and Afghanistan, the relationship between the military, nationalism, patriotism (Figure 3), hunting, and conservation manifested itself saliently in convention presentations and through colonial imagery on the showroom floor.

SCI's Annual Hunter's

Convention is not unlike large outdoor sporting retailers such as Cabela's, "as industrially produced $\underset{\text { Frecision" }}{\underset{\text { Figure 3: "Patriot }}{\text { entertainment and retailing spectacles }}}$

package tradition with consumer goods, stories about

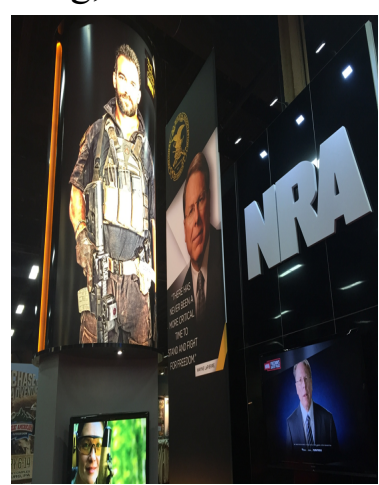

Figure 4: National Rifle Association conservation and heritage are mobilized toward economic development and commodification" (McGuigan, 2017). I continued to walk through the convention, surveying the convergence of a vast network of interdependent commercial actors with capitalist interests. Here, represented in one single space, the following can be found: safari companies and taxidermists, art galleries, picture frames, jewelry, home furnishings, optics, knives, archery, travel and tourism booking agents, lodging, hunting associations representing various countries, books and video, print and media, wineries, clothing and hunting apparel (furs, boots, hats, vests, etc.), recreational equipment, guides and outfitters, gun lobbyists such as the National Rifle Association (NRA) (Figure 4), and a combined total of 72 ammunition, rifles, guns and gun makers. I notice various hunters peeking through scopes, shouldering rifles, and weighing guns in their hands. I overhear conversations regarding the best guns for killing, experts sharing their experiences.

Representations of African wildlife appeared throughout the convention floor. These images are meant to inspire protection, awe, intervention, and mobilization. According to Igoe et al. (2010), images of Serengeti-like natures have become essential to the mobilization of people and resources for specific conservation interventions for a wide array of landscapes by hybrid networks of NGOs, state officials, and for-profit interests. Such idealized African landscapes have become the inspiration for creating African "national park landscapes"--- populated by spectacular wildlife and peopled only by paying visitors, park management, and necessary service employee (Buscher et al., 
2012). Images of conserved nature, and promises of conserving nature, are used to market everything from fast food to dish soap, and spread through the theming of space in airports, resorts, malls, botanic gardens, and theme parks (Igoe, 2010). The imagery in service to spectacle on SCI's consumer floor does not look unlike the images one is greeted with when landing in O. R. Tambo International airport in Johannesburg, or the billboard images on rural roads just outside major cities en route to Kruger or any number of game or

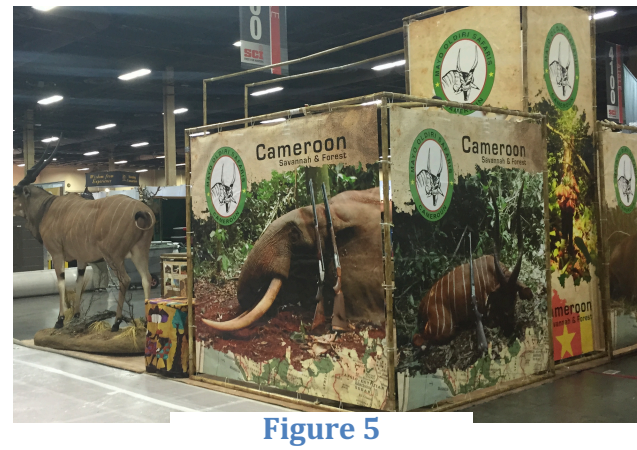
nature reserves and parks.

"Living reality is materially invaded by the contemplation of the spectacle while simultaneously absorbing the spectacular order, giving it positive cohesiveness" (Debord, 2012; Buscher et al., 2012). Consumers generally only see idealized, romanticized images of Africa, and want to do everything in their power to save it. "Even if individuals lack(ed) the resources to travel, sublime images could still arouse individual concern for the plight of Africa's wildlife that translated into protests and contributions to international conservation organizations" (Brockington, 2008;

, 2012). Convention attendees ostensibly buy into an abstracted reality that they can save the planet through material consumption. Wildlife images, taxidermy, and videos are abstractions, false representations of the material world, which merely reinforce neoliberalism. SCI showcases exotic lands from all over the world, but Africa's presence is by far the largest on the showcase floor. Africa is "portrayed as a product to be consumed" (Brockington, 2008; Mitman, 2012), a distant and exotic place packaged as entertainment and adventure.

Through a commercial grid of taxidermy, guns, and display

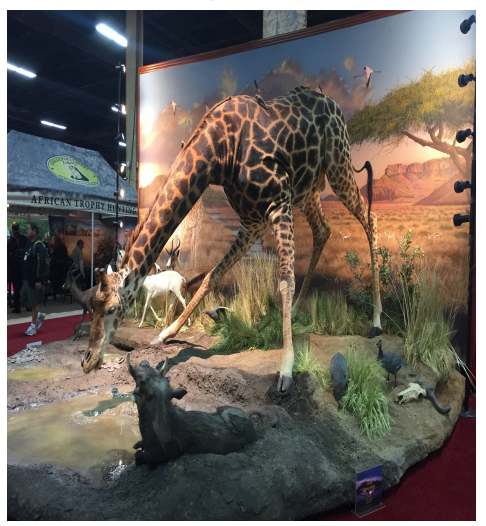
booths there are a host of hunting safari company advertisements marketing their product. One in particular that caught my eye was an image of an elephant head submerged in the red soil with its two large tusks purposefully angled forward to show their size. Two rifles lean up against its giant mass (Figure 5). Another image posted on the display booth of a Cameroonian-hunting outfitter: a mature

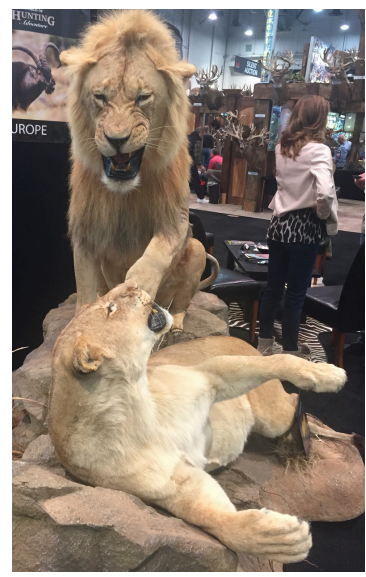

Figure 6

Figure 7 kudu, nose bloodied, the tip of its tongue peeking out its closed mouth. One rifle rests beside its lifeless body. It is altogether spectacular; nature defeated, controlled, seized by human economy. Large scrolling tapestries of charismatic megafauna festoon the rafters of the convention hall. My eyes shift more centrally and focus on a taxidermist's rendering of the African wild, or what's often represented as authentic Africa throughout the convention: lions snarling ferociously, thrashing their claws into a wounded, bloodied, snot-nosed African buffalo. Here the exotic carefully reflects the desires and expectations of trophy hunters: a wild and perfectly untamed Africa. Some hunters are drawn to the danger these animals 
represent, as they want to believe that their hunts involve an element of peril (Cohen, 2014).

In today's trophy hunting industry in Africa, however, the element of danger is mostly staged. In some cases professional trophy hunters lead international hunters to areas where they know the desired animal will not be. This is common when hunters book a 14-day hunt to kill one specific species, such as an African buffalo. If the hunter successfully shoots the buffalo on the first day, then where's the reward? Where's the story? Ultimately, leading the hunter astray at least in the first few days allows the hunter to feel his/her resilience and determination is being tested, which in effect adds value to the kill. The hunting experience becomes vastly more memorable, as the hunter earns a greater sense of accomplishment; he/she can better justify the trophy and has the dramatic story to go with it. Trophy hunters share memories of this perfect human-nonhuman encounter through the realism of taxidermy, which has been described as the "supreme achievement" of artistic representation of the nonhuman at the moment of its death (Haraway, 1989). Previously, trophy hunting in the colonial era required greater resolve and technical skill. Nowadays, elite international trophy hunters are much better equipped with the knowledge and skill of local guides and hunters, as well as every advantage afforded by the dead labor of machines (Simon, 2016). In this sense, the hunting outcome is pre-determined. Excluding rare occasions where hunters are unaware of their surroundings, such as an African Cape buffalo looming nearby a shot and felled herd member, international hunters are in no real danger (personal observation and personal communication with professional trophy hunter, 2018). On display at the convention are other spectacular diorama-like representations, such as a lioness submitting to a large male (Figure 6), giraffes bent over at an artificial watering hole (Figure 7), leopard threatening to kill a baboon perched in a tree (Figure 8), and a host of species crafted in an attempt to capture and preserve the perfection of nature and the realism of the human-wild animal encounter (Haraway, 1984). The fetish of the animal is achieved.

Trophies are conceptualized as story telling instruments (Kalof and Fitzgerald, 2003; Haraway, 1989) that convey cultural meaning and masculinity. Interviews in South Africa and the US revealed that trophy hunters prefer to tell their stories with real-life representations, and that these representations are reflective of their love, respect, and admiration for nature. One taxidermist, who is also a professional hunter and safari operator, put it this way:

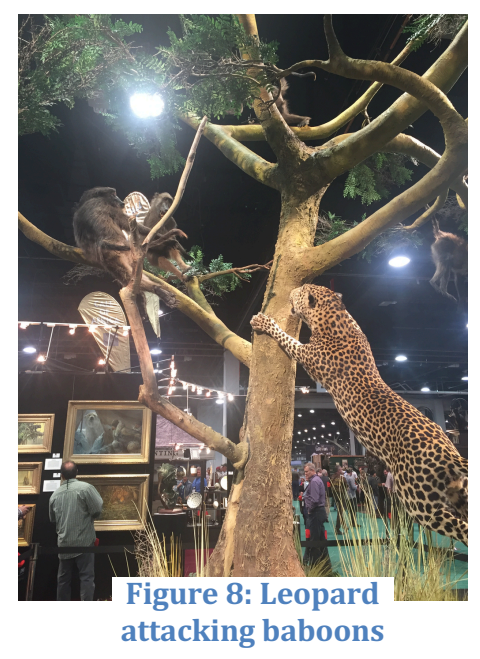

$T$ - Especially the American hunters, it's a pride thing. To start of with. I have this one client that sends me photos of his house, and says I want to put this here, I want to put this here. Because when you go into his man cave and you sit and sip on his whiskey and smoke a cigar, there's a story behind every animal. And a lot of his friends that come to his house, they don't know what's a kudu, they don't know an impala. He can tell the story. That's an impala. I shot that thing on 32 yards, or 130 yards or whatever. It's a smaller animal almost like a deer. So there's a story behind every animal... That makes the hunt. That's why this part of the 
hunt, doing the taxidermy, is so important. There's a lot of people in the industry, I tell them whoever you choose, they have good references.

Because there's a lot of guys that make...

Interviewer-You're saying a hunter can spend \$50,000 on a hunt and end up with bad trophies.

$T$-Yeah, and have nothing to show for it. Have a picture of each animal you shot, that's it. And you know you need to have a laptop on your lap and tell your friend this is a buffalo and I shot it. That's not enough. The guy wants to see it there, feel it, feel the hair, (and) see the size of it. (personal communication with game farmer, July 2018)

Another safari operator, farmer and professional hunter put it this way:

CS - You know for some people the size is important. For other people they just want a good representative animal, something that you can put on the wall that will be a conversation piece the rest of your life. You walk in there, and anybody that knows a bit of hunting, I mean a lot of people that's been through the lodge, they walk in and say geez, that's a big trophy. It's a conversation piece. I mean for us, it's also a respect for the animal to put up that trophy on the wall. And to say you know, I've hunted this animal and you know...It's not always, the trophy's is not always in the size. A lot of stuff is in the hunt. The way you hunt it. The mounts that's on the wall, each is a conversation piece on its own. If I look at it, I replay the story. It's like a photo that you take. A photo, you've got a photo and it's an implant of something from a memory. Now there are so many memories you forget them. But you take out your photo album or go for your, ahhh, yes I remember this you know, when you see that animal, it's always that memory of that animal is there, the way you hunted it, how hard it was. I mean I got a bushbuck that's number 1 on SCI. (personal communication with game farmer, July 2018)

He continued his story, emphasizing that it was a hunt requiring that he return back to an area on seven separate occasions. He had to drive 1.5 hours to get there before he could begin stalking the bushbuck.

"I managed to find it. That's hunting. To me hunting is to beat an animal on its own terrain, then you can call yourself a hunter. You go out there in the bush and you walk and you manage to get a shot at something that is a trophy to you, then you can call yourself a hunter and that's a trophy you can put on the wall" (game farmer, personal communication, 2018).

\section{Hunting "Africa”}

One video on the convention floor shows a hunter standing over a dead kudu. The hunter says (in subtitles): 
"I had wanted to hunt Africa for years. I never thought I'd see the day when I was low crawling through 600 yards of waist deep prairie grass stalking a trophy eland. I was actually thinking, 'where will he go on my wall?'

While thousands of dead nonhumans are situated in various poses throughout the convention hall, safari outfitters also use flat screen televisions that flash images of hunters stalking, shooting, and taking photos beside their prey. On display at their booths are brochures highlighting the hunting safari packages, the available species, cost, accommodation, and location. In addition, there's generally biographical information about the owners and families, their philosophy regarding conservation, how they provide a unique African experience, and photos of various staff such as skinners, trackers, and domestic employees. Most of the photos in these catalogs show smiling white hunters standing beside or behind felled trophy animals. Some of these companies also provide taxidermy services, and showcase these skills as well in their magazine-like catalogues. Kalof and Fitzgerald (2003) found extreme objectification and marginalization of dead bodies through trophy representations in hunting magazines. These representations are generally dismembered, as they are mounted on walls or become decontextualized body parts that serve the function of a table, such as elephant feet that become stools or

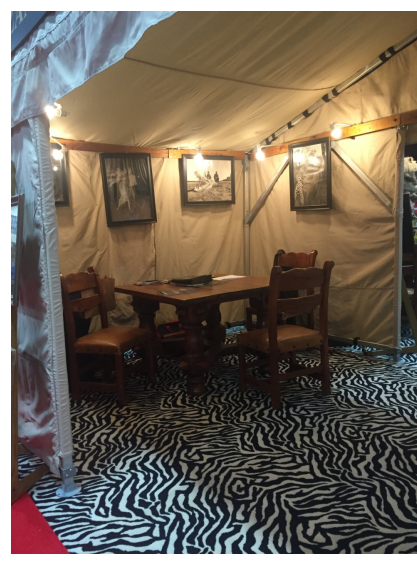

Figure 9 trashcans. They are "culturally sanctioned through discourses of art, home décor, science, and manhood" (Kalof and Fitzgerald, 2003; Desmond, 2002).

I walk past a number of hunting outfitter tents, set up in the colonial manner: skins adorn wooden chairs or are splayed out as giant rugs. Decorating the walls are maps, hunting photos in the Theodore Roosevelt tradition, and images of pristine, people-less African landscapes (Igoe, 2004) of elephants and other wildlife in silhouette juxtaposed to acacia filled landscapes. I enter one such colonial depiction (Figure 9) and engaged in a conversation about hunting elephants with a Professional Hunter (PH). After asking him about what happens to the elephant following the taking of its life, he insisted on showing me a video of the hunt. It was important for him to convince me that "nothing goes to waste." The video was proof of this claim, as a number of people from a neighboring community gathered around the felled animal to cut up and parcel out the meat. Apparently 3,000 people would "not go hungry." The American hunter consequently feels justified in hunting an iconic species, as he's feeding poor and helpless black African people. In other words, this action reflects an ongoing "hegemonic representation of the West as giver and Africa as the receiver", where Africans are children that have become "natural objects of "humanitarianism" through their "corollary identification as quintessential Others against which the West constructs its own image" (Mostafanezhad, 2013; Said 1978; Mathers, 2011). Rural Africans thus remain dependent on the good will of the white hunter. When pressed further about what he does with the tusks, he proudly boasted that they would stand on either side of his fireplace at home. As for the disembodied feet, they would act as "wastebasket holders" in his man cave. 
Another example of paternalism and humanitarianism was a promotional video on a flash-drive dispensed by the Professional Hunter's Association of South Africa (PHASA). The short film is called "A Conservationist Cry," which is meant for international trophy hunters to learn about how their contributions help save species from extinction, and indigenous people from becoming desperate poachers. On the surface, there's an attempt to humanize rural Africans, but the result is politicization and woefully ahistorical. The beginning of the video stages a dialogue of a small group of San sitting around a campfire in a solemn mood. The film frames the San as vulnerable to the (temporary) trophy hunting ban in Botswana. One says, "They no longer give us meat. My family needs to eat." Another says, "With no work, I can't afford medicine for my little one. I will hunt. Perhaps I will bring back an eland for us to eat. Another person says, "Don't joke. If they catch, they will take you in the big truck." (Figure 10)

The message is clear: if there is no trophy hunting, then men will be forced to "poach" and then be wrested away from their families by the State. Put another way, without revenue from international trophy hunting, there is no money for the protection of wildlife, and no money for the local people who will fall sick, hungry, and die. One

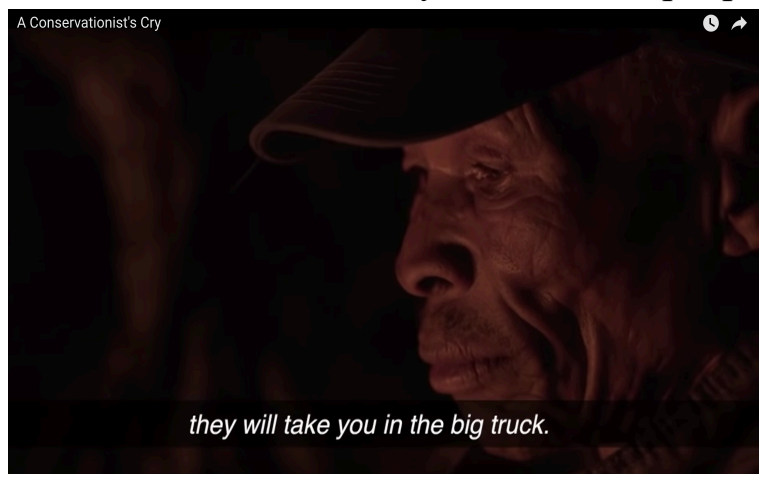
goes on to say, "There was once hunting, a water hole with pump. No longer." "They said that we will get money from photo tourism, but we still wait." These last words trail off into sad music that is juxtaposed to a desolate landscape. A falling rock appears. Vultures fly overhead. This is a story about how much hunters care about indigenous people, how

Figure 10 decisions from afar impact local people in unimaginable ways. It's a story that supposedly left-leaning conservationists remain unaware. The main point is that taking hunting away from local people will turn them into criminals. The "conservationists cry" is the hunter weeping for nonhumans and humans that only white hunters can save. Statistics of species extinction flash before the screen that are meant to shock and motivate the hunter. A number of game ranchers from Namibia and South Africa are interviewed, one who states, "A few of these animals have to die to support the others. They have to. If we hope to preserve the wildlife we will have to continue to hunt. There is just absolutely no other way" (PHASA promotional material, 2018). The film cuts back to the San. The campfire is nearly reduced to ashes. A couple of small flames linger. The San stare intently at the disappearing fire. The screen goes black. We are then drawn into heart-rending, viscerally moving images: An impala struggling for its life in a snare. An elephant carcass, face removed. A faceless, bloody rhino still moving its head. These images are meant to represent the harsh reality, the destiny of wildlife when there's no money from trophy hunting to protect it. The narrator's voice emerges:

"When it's your chance to vote, will you vote for the wildlife and the people of Africa, people whose very lives are invested in wildlife, or will you vote for the popular misconception spawned by social media that's generated by the city 
The following words then populate the screen: "These are real people. Real facts. The greatest threat to wildlife is the thought that someone else will save it." The problems that Africans face cannot be left to environmental and animal welfare NGOs in the US or Europe. Hunters can save African wildlife. The last quote sows PHASA's cynical appeal to the white man's burden. While this video does not utilize the usual African images of a pristine landscape, it intentionally engages in discourses necessitating a white humanitarian interventionism. "Africa the most 'authentic' volunteer site and the Third World child has become a dominant signifier of modern humanitarianism" (Mostafanezhad, 2013). I would argue that while trophy hunting may not technically qualify as volunteerism, its motivations are akin to the Westernized, humanitarian impulse to save the Third World child. PHASA simply exploits this ethos, and in the process potentially reproduces colonial narratives of a helpless Other dependent upon the good deeds of white trophy hunters. PHASA also recognizes that US hunters, much like white South African game farmers who perceive persecution and victimization, lament the loss of tradition, and fear a loss of culture, conservatism, and livelihood, are entangled in a cultural war with "city dwelling people," and use this language to convey cultural solidarity.

The convention holds a series of sessions that build on the themes of humanitarianism, paternalism, and consensus-making. Some of them include Encouraging Women to Pull a Trigger, Your First African Safari, Planning and Designing Your Trophy Room, Hope for African Hunting, and How Can You Kill Those Beautiful Animals? Words and Stories We Must Speak to Preserve Hunting, and the Future of Elephant Conservation. In the latter session, anti-poaching staff from Humanitarian Operations for the Protection of Elephants (HOPE), Zambeze Delta Safaris and Charleton McCallum Safaris advocated for increased security of wildlife. The session began with a question by HOPE, an organization that also champions "sustainable" hunting practices: "Is there any person in the room who does not believe that hunting is an integral component to conservation and that it should be protected?" Not a single hand was raised. A former Special Operations officer then spoke to working with local communities on the ground, and emphasized the military approach, explaining the importance of learning the social and economic dynamics of the region before intervention. He mentioned that change could only happen by talking to people in the area, that NGOs have to change with the local communities, and by "having them be the change." Although attention is given to indigenous and rural populations, they are more obstacles than true stakeholders in the process (Brandt et al., 2018). The message is clear: rural, poor people need to change, and it is their responsibility to do so. Saddling local populations with environmental protection begins with apolitical and ahistorical ecologies presupposing that poor people are the number one threat to wildlife and should act to police themselves for fear of unsustainable harvesting of wildlife species and a "tragedy of the commons" (Hardin, 1968). Decentralization of environmental governance depends on these narratives that permit new technologies of power and results in environmentality Agrawal et al. (2005), which is the "transformation of local people into new political-environmental subjects." Rather than seriously discussing the history of conservation in relation to environmental marginalization and degradation (Robbins, 2011), the former special ops officer delivers an oversimplified explanation necessitating 
intervention. It is a humanitarian plea; one paternalistically framed as one in which only Western ingenuity can reverse the scarcity of nature (Harvey, 1993). He went on to mention that HOPE's goal is to "affect change in conservation, affect change in country, and affect change in national security that allow the illicit funding of poaching," and that they can do this by "tracking the bad people that do bad things." This particular discourse reflects what Agrawal (2005) referred to as environmentality, or rather "shaping conduct through a multiplicity of authorities and agencies in and outside the state at various spatial levels maintaining power for purpose of security and regulation" (Peet \& Watts, 2004; Homer-Dixon, 1999). A larger group discussion unfolds following the presentation, many in attendance championing enhanced technological surveillance and security to protect elephants.

A meaningful critique or disavowal of violence could not be found in the session. The idea is that we, the white international conservationists, are "responsible for protecting" (Duffy, 2015) species that cannot protect themselves. Buscher and Ramutsindela (2016) view the war on poaching in a wider political-economic and historical perspective in order to provide a deeper understanding of why many actors respond to the poaching crisis with what they call green violence: "the deployment of

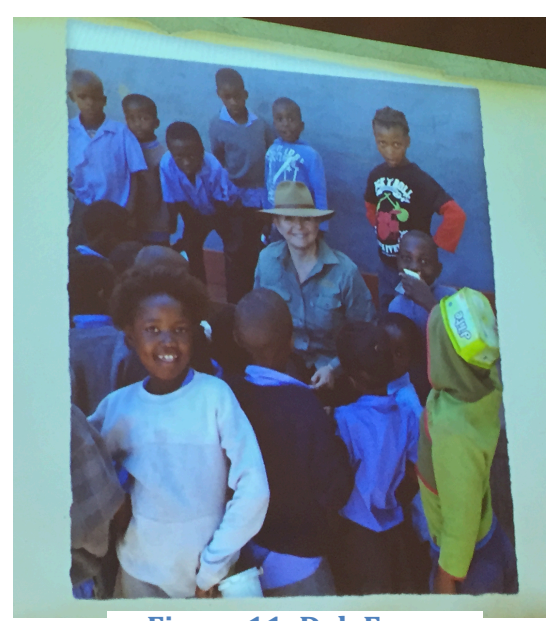

Figure 11: Deb Ferns violent instruments and tactics towards the protection of nature and various ideas and aspiration related to nature conservation." They pay particular attention to "peace parks": large conservation areas that cross international boundaries, and show that saving these parks is becoming, ironically, an increasingly violent affair. According to Buscher and Ramutsindela (2016), two factors help to legitimize and encourage green violence. The first is "the historical positioning of peace parks in the region as the 'telos' of conservation, with little consideration for the region's violent past, while the second is popular discourses that place poachers in a 'space of exception' (Agamben, 1998) where their right to life no longer applies" (Buscher and Ramutsindela, 2016). Social media platforms online celebrate the death of poachers, much like Americans celebrated the death of Osama bin Laden. The discursive construction of the African poacher/Other and the normalization of shoot-on-sight directives create a potent moral geography centered on African national parks as ground zero in the war to protect global biodiversity (Neumann, 2004). Moreover, social violence signifies that actors are willing to engage in a broad range of violent tactics to support their objectives of biodiversity conservation. The session Encouraging Women to Pull a Trigger was led by NRA member Deb Ferns (Figure 11). She's co-founder of a program called "Babes for Bullets," which is designed to "help women overcome their fear of firearms, to become educated about the tools and its users." In this session, she encouraged growth in the firearms market and argued for the protection of 2 nd Amendment rights. One PowerPoint slide explicitly stated "You run the gun...the gun does not run you!" Her pro-gun message here was preceded by a short video meant to inspire women to hunt. She set up a video clip by explaining how a young female hunter was attacked by a black bear while hunting deer in Montana. After six 
months, the young girl decided to hunt again, but this time she would hunt a black bear. The video shows two black bears peacefully foraging on berries hanging from bushes at the edge of a leafy meadow. The young girl smiles, sets her tripod up, rests her rifle upon it, and pulls the trigger. One of the bears falls down to the ground. She shoots again for good measure. The bear is dead (Figure 12). The other bear runs away. At this point Deb turns the lights back on and speaks to the inspiring nature of the story, how the young girl was able to summon up the courage to hunt again. She shows the trophy-hunting photo of the girl and her family with beaming smiles sitting behind the felled bear.

A different interpretation would posit that this is a story of a young girl who arbitrarily selected and killed a bear unrelated to her previous attack. The hunt was more about overcoming her fears and making herself

feel better than conservation. In essence, this was a therapeutic kill: a bear's life was taken for the sake of one's emotional and psychological repair, yet the kill is framed and celebrated as courage. Heads nod in agreement. Deb later describes a hunt in which she killed a longhorn sheep, remarking how "God wanted me to have that one."

She ends her presentation with a slide that unequivocally demonstrates that women are a

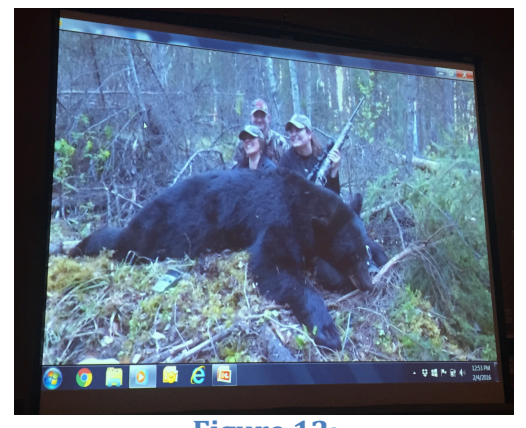
targeted demographic to increase gun manufacture sales (Figure 13). In 2001 only $10 \%$ of hunters were women, whereas by 2013 they made up 19\% (http://nssf.org/hunting).

She then emphasized the common refrain, 'guns don't kill people, people kill people', meaning that "antis" are misguided in their attempt to undermine the $2^{\text {nd }}$ Amendment. As an NRA member, Deb is less concerned about getting women to pull the trigger than

Figure 12: Psychological repair boost gun manufacture sales and strengthen cultural identity.

Safari Club International has made concerted efforts though to draw women into trophy hunting, as a number of women have been featured on the cover of their Safari Times monthly newsletter (Figure 14). Here we can see how the measurement of the animal is given and followed by references to hunting heritage and protecting the freedom to hunt. Left out of the newsletter is that the heritage of trophy hunting is terribly violent, and an exclusionary hobby born of capitalist differentiation and enjoyed by the leisure class.

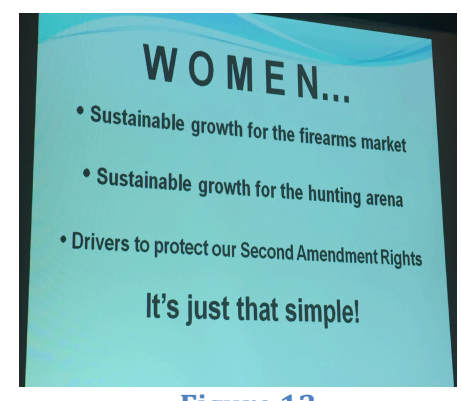

Figure 13 


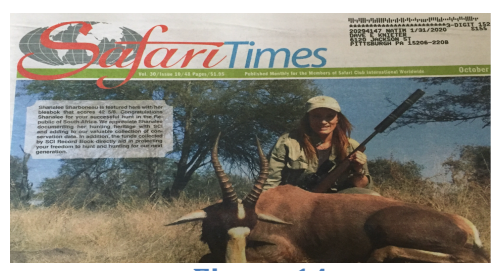

Figure 14

Trophy hunters at the convention did not make the distinction between trophy hunting and subsistence hunting, instead choosing to conflate the two. The size of the horn is an essential component to the trophy-hunting story. The size is discussed between the safari operator, game farmer, professional hunter, and clientele. Safari operators work hard to ensure that they can meet the demands of their international clients, and in some cases will go to wildlife auctions to buy the specific individual species that fits the client's criteria. This improves client satisfaction and leads to better testimonials that are found on safari websites and the brochures that are distributed at the convention. This relationship between client and safari operator has strengthened the wildlife ranching industry that farms wild animals (Carruthers, 2008) to be killed as trophies or bred as studs.

In Your First African Safari, Craig Boddington, a professional hunter, contributor to Safari Times, television host, author of many hunting books, and can be seen advising elephant hunters about shot placement ("Center in the forehead is correct.") (https://m.youtube.com/watch?v=B36Ypyg_JL, retrieved April 2019), led a panel discussion in front of an all white audience with the purpose of offering the prospective hunter all the necessary information they would need regarding guns, permits, applications, fees, safari companies and laws prior to a hunt in Africa. Additionally, his words sought to address and put hunters at ease regarding the tightened import restrictions on lion and elephant trophies. In reference to a first time Africa hunting experience, he said that "It is a life changing event. I know that some of you plan on going there to get it out of your system....Not going to happen. It is a matchless feeling." Later, after acknowledging the new restrictions, he says,

"Let's not be all gloom and doom here. We all know that the elephant importation is a disaster right now. What happened with the lion is a greater disaster, but that does not mean that African hunting is on its way out. Things come and go; it follows a bell curve. Right now there are so many more countries available right now."

Craig Boddington attempts to assuage the crisis moment with promises of future hunts. The industry has been previously set back with import restrictions in Zimbabwe and Zambia with elephants (loosened in 2017), and lions and leopards from South Africa. Botswana enacted a hunting ban altogether (removed July 2019). Hunters frame this as being under siege, as previously discussed earlier in the paper. It also speaks to how "Africa" is left to fend for itself against unfair legislation guided by an environmentalist elite. Lastly, the notion that one is not being able to get Africa "out of your system" speaks to the broader, exotic spell that feminized Africa has over the masculine Western hunter.

Observations at SCI revealed that while a number of white South Africans understand conservation in the context of dispossessing black Africans from their land, American understandings of African conservation are appallingly ahistorical. These shortcomings can be attributed to frontier mythology that generally fails to recognize the displacement of indigenous people in North America in the production of conservation icons such as Yellowstone National Park. The political and social complications and 
contestations inherent to nature enclosures go virtually ignored by Americans. Processes of alienation and marginalization are obfuscated; meanwhile rural livelihoods are made more vulnerable. The fact is that conservation has been disastrous for many rural, indigenous, and local communities who have historically been dispossessed of land and who currently have legitimate land tenure claims. However, the fact that neoliberal conservation hunting enclosures, the ones typically found in South Africa, remain the panacea for meeting multiple state and international conservation goals deserves critical engagement.

"If it pays, it stays," the CEO of PHASA told me. A number of South African game farm owners echoed this sentiment as well, some launching into greater detail than others. One particular farmer explicitly stated that monetary incentives to save animals must be in place. For example, he said that if leopards weren't legally available to be trophy hunted, then farmers that spot them on their land would shoot them for fear of losing their other game. Herein lays the contradiction: leopards are not valued according to conservation principles that seek ecological protection and genetic diversity and health, but are rather valued according to fixed prices on the marketplace. The argument goes that if the leopard had an economic value then there would be an incentive to protect it. Because all species are not valued or produced the same, owners will make calculated business decisions that favor certain species over others. Hunters will argue that they're forced to make these decisions because of outside interference that has made species such as leopards off limits until enough scientific data has been collected that provides evidence of a sustainable population. Game farmers have admitted that they know other farmers who simply trap these "vermin" species and kill them. This means that environmental laws have adverse effects on the species they're meant to protect. On the other hand, this speaks to larger problems in the hunting industry that have focused too much on breeding super species for international clients drawn to trophy hunting record books (SCI, Rowland Ward, Boone and Crocket). Hunting can have adverse impacts on specific species, particularly reduction in genetic biodiversity, resilience, and ecological disturbance. The solution in South Africa has been wildlife ranching facilities that intentionally breed specific species to meet market demand. Intensive breeding production guarantees genetic replacement. It also guarantees the ability to meet market trends, and so the relationship of breeding and hunting is categorically a win-win scenario; hunters have an endless surplus of species to choose from while breeders have a market demand.

\section{Conclusion}

The purpose of SCI's Annual Hunter's Convention is to stimulate economic interest. No longer does conservation serve to critique the deleterious effects of capitalism; it rather reappropriates its logic to advance its own interests and expansion. At present, conservation involves the killing of wildlife that favors private capital accumulation. Recall how the presenter at the beginning of the session The Future of Elephant Conservation asked if anyone disagreed with her about hunting for conservation. This question was not intended to spark debate, but rather to silence any alternative views, values, practices, or conceptions of nature. It was quite simply meant to establish consensus, one that calls for increased surveillance, policing, and militarization of local environments in the war against wildlife crime/poaching. Conservation has long 
had deep military roots, but it saw an intensification of militarized practices in the $1980 \mathrm{~s}$ (Lunstrum, 2014). By the 1980s within official and popular conservation rhetoric, wildlife began to be understood as belonging to an expanded moral community, as poachers were denigrated as ruthless and morally lacking (Neumann, 2004). Such assumptions have led to a "just war" (Lunstrum, 2014). Elizabeth Lunstrum's (2014) unpacks this ongoing practice in the article Green militarization: Anti-Poaching Efforts and the Spatial Contours of Kruger National Park. In this article she focuses on the convergence of conservation and militarization, called green militarization, challenging the increased use of military and paramilitary personnel, technologies, and partnerships used in the pursuit of conservation efforts (Lunstrum, 2014). Green militarization carries with it further unanticipated consequences, namely the creation of dangerous spaces for innocent bystanders who risk getting caught in the crossfire (Neumann, 2004; Lunstrum, 2014). The most weighty, long-term consequences, however, might be the related to damaging social relationships within communities where people are transformed into police informants (Lunstrum, 2014). Additionally, the militarization of conservation has generated an arms race, one in which rangers and poachers literally race to procure more advanced killing technology. At the convention I was told that killing poachers is a last resort, and that they prefer to utilize GPS, drones and surveillance cameras, and pay local community members, some of whom are 'reformed' poachers, to search and identify traps and snares. They maintained that utilizing such technology, community support, and militaristic strategies, coupled with elite eco-hunting safaris was the superior model. They maintained that killing wildlife the "legal" and more moral way, helps feed communities and shows them that 'incentivizing the kill' pays long-term dividends. Green violence thrives on asymmetrical power relations and assumptions about land use and environmental degradation rooted in Western science and (post)-colonial discourse, as well as taken-for-granted market-based ideologies, policies and practices geared towards rescuing and repairing global biological diversity. An apolitical crisis of conservation narrative has essentially been constructed through a vast hegemonic network of international financial institutions, development agencies, NGOs and publicprivate actors and partnerships, offering a grim picture of 'pristine' nature under threat, a world in which global charismatic species are under attack and endangered on account of "poachers" and criminal syndicates. Killing to keep the planet green, or rather killing to ensure the continued accumulation of green (capital) is only acceptable if committed by international white hunters. On the other hand, it is criminal for local communities, or rather the "poacher/Other" (Neumann, 1997) to hunt. Since the failure of the communitybased conservation turn in the 1990s, the conservation community and its donor agencies have (re)turned to a fortress enclosure ethic emboldened by neoliberal logics of privatization and the commodification of nature which has led to new nature enclosures and technocratic investment in military technologies and strategies to stimulate economic growth and sustainable development, alleviate poverty, and win the 'war on biodiversity' (Neumann, 2004).

The trophy hunting industry uses conservation as a vehicle to reproduce, rebrand, and market a very colonial hunting heritage. References to "hunting Africa," as well couching critique in feminine terms reflects a pervasive masculinity inherent to the colonial practice of trophy hunting. Goodrich (2016) argues "hunting nature is a commodity that anchors a past nationalist masculine hierarchy in a reciprocal relationship 
to game on privately owned land and collapses belonging into ownership." Additionally, the industry is apprehensive about meeting the crisis of not being able to hunt, use their guns, and take "what is rightfully" theirs. The hunting community resembles a community in crisis, one seeking to green itself for the sake of economic repair. New valuations of nature are legitimizing and incentivizing new appropriations, and multiplying them, as ecosystems become compartmentalized and commodified in an ever greater variety of ways (Fairhead et al., 2012). Hunters are acting more like conservationists of hunting, looking to preserve their right to arms and the places in which they can hunt and kill. Maintaining these epistemologies requires spectacle and continued alliances with right-wing politicians and the gun lobby. The direct implications for conserving the hunting industry means the denial of more systematic, integrated, holistic dynamics of ecosystems ---- and the social-ecological relationships through which people live with and shape these (Fairhead et al., 2012). Moreover, "the pervasiveness of green market logics and valuations of nature in global discourses, media and consumer practices makes it too easy to dismiss peasant resistance as individual, isolated opposition: not as valid social mobilization, but anachronistic holding-out against a common-sense green tide" (Fairhead et al., 2012).

To conclude, this paper advances the scope of political ecology, as it emphasizes the significance of bringing right wing politics into conversation with trophy hunting in the context of international conservation. We can apply the term right wing political ecologies to a how complex cultural, political, and economic processes of neoliberalizing nature open new opportunities for wildlife exploitation through a cynical co-optation of the "green" economy. The industry employs three major themes that serve to drive trophy hunting at hunting conventions and multifarious media, which include the utilization of colonial representations of wildlife imagery and Africa, hunting humanitarianism and paternalism, and a politics of difference. The culmination of these themes is distinctly right wing. Geographers have heretofore barely scratched the surface in terms of exploring the impacts of right wing politics on international wildlife conservation and how it functions in time and space. Lack of meaningful critique allows state and non-state actors to drive a discourse rooted in colonial hierarchies and economic logic that has deadly consequences. The final implication is the continuation of green violence, a world in which humans and nonhuman animals are reduced to bare life, remain there and alive for the kill. Using Safari Club International Annual Hunter's Convention as a site for critique provides us with significant insight into how discourses justify this exploitation, and in doing so should signal a call for greater exploration of such sites and how they work in tandem with state and non-state actors, as well as the formation of national and international conservation policy.

Works Cited

Agamben, G. (1998). Homo sacer: Sovereign power and bare life. Stanford University Press.

Agrawal, A., Gupta, A., Hathaway, M., Narotzky, S., Raffles, H., Skaria, A., ... \& Agrawal, A. (2005). Environmentality: Community, intimate government, and the making of environmental subjects in Kumaon, India. Current anthropology, 46(2), 161-190. 
Barua, M. (2017). Nonhuman labour, encounter value, spectacular accumulation: The geographies of a lively commodity. Transactions of the Institute of British Geographers, 42(2), 274-288.

Beinart, W. (2000). African history and environmental history. African Affairs, 99(395), 269-302.

Beinart, W. and Coates, P. (2002). Environment and history: The taming of nature in the USA and South Africa. Routledge.

Briziarelli, M., \& Armano, E. (2017). Introduction: From the notion of spectacle to spectacle 2.0: The dialectic of capitalist mediations.

Broch-Due, V., \& Schroeder, R. A. (Eds.). (2000). Producing nature and poverty in Africa. Nordic Africa Institute.

Brockington, D. (2008). Powerful environmentalisms: conservation, celebrity and capitalism. Media, culture \& society, 30(4), 551-568.

Brockington, D., Duffy, R., \& Igoe, J. (2008). Nature unbound: conservation, capitalism and the future of protected areas. Earthscan.

Brooks, S., Spierenburg, M., Van Brakel, L. O. T., Kolk, A., \& Lukhozi, K. B. (2011). Creating a commodified wilderness: Tourism, private game farming, and 'third nature' landscapes in Kwazulu-natal. Tijdschrift voor economische en sociale geografie, 102(3), 260-274.

Büscher, B., \& Ramutsindela, M. (2016). Green violence: Rhino poaching and the war to save Southern Africa's peace parks. African Affairs, 115(458), 1-22.

Büscher, B., Sullivan, S., Neves, K., Igoe, J., \& Brockington, D. (2012). Towards a synthesized critique of neoliberal biodiversity conservation. Capitalism Nature Socialism, 23(2), 4-30.

Büscher, B. (2013). Transforming the frontier: peace parks and the politics of neoliberal conservation in Southern Africa. Duke University Press.

Craggs, R., \& Mahony, M. (2014). The geographies of the conference: Knowledge, performance and protest. Geography Compass, 8(6), 414-430.

Cohen, E. (2014). Recreational hunting: Ethics, experiences and commoditization. Tourism Recreation Research, 39(1), 3-17. 
Corson, C., \& MacDonald, K. I. (2012). Enclosing the global commons: the convention on biological diversity and green grabbing. Journal of Peasant Studies, 39(2), 263-283.

Cousins, J., Sadler, J., \& Evans, J. (2008). Exploring the role of private wildlife ranching as a conservation tool in South Africa: stakeholder perspectives. Ecology and society, 13(2).

Debord, G. (2012). Society of the Spectacle. Bread and Circuses Publishing.

Desmond, J. (2002). Displaying Death, Animating Life: Changing Fictions of 'Liveness' from Taxidermy to Animatronics. Representing animals, 26, 159.

Duffy, R. (2015). Responsibility to protect? Ecocide, interventionism and saving biodiversity. Organised by Political Studies Association: University of London, March, 30 .

Fanon, F., Sartre, J. P., \& Farrington, C. (1963). The wretched of the earth (Vol. 36). Grove Press.

Fairclough, N. (2013). Critical discourse analysis: The critical study of language. Routledge.

Fairhead, J., Leach, M., \& Scoones, I. (2012). Green Grabbing: a new appropriation of nature?. Journal of Peasant Studies, 39(2), 237-261.

Goodrich, A. (2016). Enacting and stabilizing the nature of colonial history through hunting in the South African Highveld. Journal of Contemporary African Studies, 34(1), 22-39.

Hardin, G. (1968). The tragedy of the commons. science, 162(3859), 1243-1248.

Harvey, D. (2018). The limits to capital. Verso books.

Harvey, D. (1993). The nature of environment: dialectics of social and environmental change. Socialist Register, 29(29).

Haraway, D. (1984). Teddy bear patriarchy: taxidermy in the Garden of Eden, New York City 1908-36. Social Text, 2, 19-64.

Haraway, D. J. (1989). Primate visions: Gender, race, and nature in the world of modern science. Psychology Press.

Haraway, D. J. (2013). When species meet (Vol. 3). U of Minnesota Press. 
Herman, D. J. (2003). The hunter's aim: The cultural politics of American sport hunters, 1880-1910. Journal of Leisure Research, 35(4), 455-474.

Homer-Dixon, T. (1999). Thresholds of turmoil: environmental scarcities and violent conflict. Contested Grounds: Security and Conflict in the New Environmental Politics, 61-90.

Igoe, J. (2004). Conservation and globalization: A study of national parks and indigenous communities from East Africa to South Dakota. Wadsworth Publishing Company.

Igoe, J. (2010). The spectacle of nature in the global economy of appearances: Anthropological engagements with the spectacular mediations of transnational conservation. Critique of Anthropology, 30(4), 375-397.

Igoe, J., Neves, K., \& Brockington, D. (2010). A spectacular eco-tour around the historic bloc: Theorising the convergence of biodiversity conservation and capitalist expansion. Antipode, 42(3), 486-512.

Jackson, P., \& Russell, P. (2010). Life history interviewing. The Sage handbook of qualitative geography, 172-192.

Jessop, B (2004). Critical semiotic analysis and cultural political economy. Critical discourse studies, 1(2), 159-174.

Kalof, L., \& Fitzgerald, A. (2003). Reading the trophy: Exploring the display of dead animals in hunting magazines. Visual Studies, 18(2), 112-122.

Kamuti, T. (2014). The fractured state in the governance of private game farming: the case of KwaZulu-Natal Province, South Africa. Journal of Contemporary African Studies, 32(2), 190-206.

Kheel, M. (1996). The killing game: An ecofeminist critique of hunting. Journal of the Philosophy of Sport, 23(1), 30-44.

Kovel, J. (2007). The enemy of nature: The end of capitalism or the end of the world?. Zed books.

Laurier, E. (2010). Participant observation. Key methods in geography, 133.

Longhurst, R. (2003). Semi-structured interviews and focus groups. Key methods in geography, 3, 143-156.

Lovelock, B. (2007). An introduction to consumptive wildlife tourism. In Tourism and the Consumption of Wildlife (pp. 25-52). Routledge. 
Lunstrum, E. (2014). Green militarization: Anti-poaching efforts and the spatial contours of Kruger National Park. Annals of the Association of American Geographers, 104(4), 816-832.

MacDonald, M. (2006). Why race matters in South Africa. Harvard University Press.

MacKenzie, J. M. (1997). The empire of nature: Hunting, conservation and British imperialism. Manchester University Press.

Marx, K. (2015). Capital: A critique of political economy, Volume 1. Arsalan Ahmed.

Mathers, K. (2011). Travel, humanitarianism, and becoming American in Africa. Springer.

Matthews, J. D. (2005). An introduction to the situationists. Black Powder Press.

McGuigan, L. (2017). The hunting industry: Exploring the marriage of consumerism, sport hunting, and commercial entertainment. Journal of ConsumerCulture, 17(3), 910-930.

Mitman, G. (2012). Reel nature: America's romance with wildlife on film. University of Washington Press.

Mostafanezhad, M. (2013). The geography of compassion in volunteer tourism. Tourism Geographies, 15(2), 318-337.

Neumann, R. (1997). Primitive ideas: protected area buffer zones and the politics of land in Africa. Development and change, 28(3), 559-582.

Neumann, R. P. (1998). Imposing wilderness: struggles over livelihood and nature preservation in Africa (Vol. 4). University of California Press.

Neumann, R. P. (2004). Moral and discursive geographies in the war for biodiversity in Africa. Political Geography, 23(7), 813-837.

Peet, R., \& Watts, M. (2004). Liberation ecologies: environment, development and social movements. Routledge.

Pérez, M. A. (2017). Conferencing Cuba's geographies of speleology: The politics of inclusion and hospitality among cave explorers and scientists. Human Geography, 10(3), 79-96.

Ramutsindela, M., Spierenburg, M., \& Wels, H. (2013). Sponsoring nature: Environmentalphilanthropy for conservation. Routledge. 
Robbins 1, P., \& Luginbuhl, A. (2005). The last enclosure: resisting privatization of wildlife in the western United States. Capitalism Nature Socialism, 16(1), 45-61.

Robbins, P. (2011). Political ecology: A critical introduction (Vol. 16). John Wiley \& Sons.

Schroeder, R. A. (1999). Geographies of environmental intervention in Africa. Progress in human geography, 23(3), 359-378.

Sharp, J. (2008). Geographies of postcolonialism. Sage.

Simon, A. (2016). Against trophy hunting: a Marxian-Leopoldian critique. Monthly Review, 68(4), 17.

Snijders, D. (2018). Controlling Sex and Death: On the Wildlife Trophy Industry in South Africa. In Nature Conservation in Southern Africa (pp. 214-232).

Said, E. (1978). Orientalism. New York: Pantheon, 80.

The Humane Society International and the Humane Society of the United States. (2016). Trophy hunting by the numbers: The United States Role in Trophy Hunting. Retrieved from https://hsi.org $>$ assets $>$ pdfs $>$ report trophyhunting_by the_numbers

US Department of the Interior, United States Fish and Wildlife Service. (2016). National Survey of Fishing, Hunting, and Wildlife-associated Recreation. Retrieved from http://wsfrprograms.fws.gov>subpages $>$ nationalsurvey>nat_survey 2016 


\section{Chapter 2}

\section{A Nature Commodified: The Production of Life, Death, and Capital in South Africa's Wildlife Economy}

\section{Abstract:}

In this paper I argue that the logics underpinning the neoliberalization of nature only nurture new illogics whereby species' complexity disappears in a process of deanimalization reducing nonhumans to biocapital. It is the author's view that processes of nature production are very much manifestations of speculation (McDermott, 2005), investment, public-private partnerships (Snijders, 2019), and biopolitics (Biermann and Anderson, 2017). The production of nature, or more specifically the breeding of nonhumans for trophy hunting is a manifestation of discursive struggles over the meanings, categorizations, techniques, and definitions of concepts and terms that justify and guide the valuation and use of nonhumans for profit. These particular nature production processes occur in response to international hunting expectations and trends that are often at odds with the tenets of conservation. I build on recent research by Spierenburg, Kamuti, and Snijders $(2014 ; 2019)$, who combine to critique the socioeconomic and political processes and frameworks guiding the wildlife ranching and trophy hunting industry, and the degree to which they wield control over the life cycles of nonhumans from birth through death. Trophy hunting and game breeding advocates, having accessed the levers of power in South Africa's green economy (Cousins et al., 2010), transformed the genetic capture of specific traits into super species of increased horn and body size, and increased profits for industry actors. Premiere wildlife ranchers such as Bona Bona, Thaba Tholo, and Crown Breeders maintain they produce the best bloodlines that diversify and replenish gene pools, which overall serve to improve conservation and rural development outcomes. However, as this livelihood production functions as part of the global economic machinery of basic supply and demand, nonhumans may be overproduced and undersold, causing wildlife ranchers to make unsentimental business decisions that disrupt the ability of nonhumans (Batavia et al., 2018) to live out their "wild" lives (Snijders, 2012). The breeding of high value species, or farming the wild (Carruthers, 2008) such as sable, roan and buffalo, as well as color variants (black and copper impala, golden wildebeest, golden gemsbok), is thus scrutinized in the context of a nature conservation once meant to act as a safeguard against capitalism versus one in service to it. This paper reveals the aggregate perspectives and practices that produce biocapital and lively commodities (Haraway, 2013; Collard, 2014; Barua, 2016, 2017) by drawing on participatory observations and semi-structured interviews at auctions and wildlife ranches in South Africa's green economy. Industry attitudes, perceptions, and contradictions of wildlife ranching are discussed and assessed as it relates to the overall production and commodification of nature.

"The production of nature at the global scale, not just a complete mastery over nature, is the goal of capital." - Uneven Development, Neil Smith (2008) 
"They're beautiful animals, it's just that if they were rare they'd be so much more value. Springbok and impala are beautiful animals but because they're common people don't give them the attention they really deserve." (Personal communication, 2018)

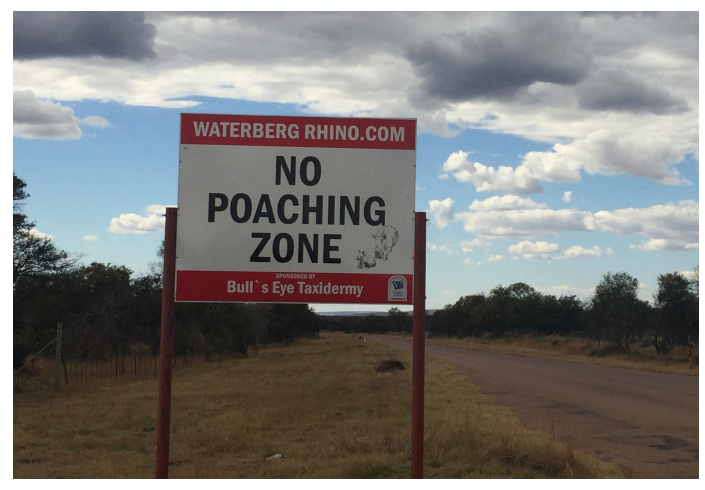

\section{Introduction}

Driving to the Mpatamacha Game Capture wildlife auction in the rural province of Limpopo, I'm reminded of the discursive and material struggle over the commodification of nature. Every few kilometers I pass roadside signs in bold print declaring the area a "No Poaching Zone," signifying the ongoing rhino-poaching crisis in South Africa. Hundreds of rhinos are killed in South Africa every year, though this past year has seen a significant reduction to where only 5 years ago more than 1,200 rhinos were slaughtered. In a war against a vast network of criminal syndicates and profiteers, South Africa National Parks (SANParks), local conservation agencies and security enforcement patrol nearby protected areas and set up checkpoints to prevent the illicit and violent trade of rhino horn. South African wildlife ranchers and trophy hunters currently lobby to legalize the international trade of rhino horn believing that it will reduce poaching pressure, as flooding the market would be "easy" considering the large stockpiles of horn that private game ranchers have accumulated (interview summer 2018 with game farmer). To date, permits to trade horn domestically have been granted (DEA, 2018), but in very small number and do not appropriately incentivize farmers to own and securitize rhinos and rhino horns (interview with John Hume, 2018). Because protecting and feeding rhinos is so expensive, farmers attempt to sell them regionally and internationally to nature reserves, sanctuaries, and zoos. Some invite investors from overseas to cover the expenses necessary to care for them, trim their horns, and protect them until rhino horn one day becomes legally available as an internationally tradable commodity (https://buffalodreamranch.com/adopt-a-rhino/ retrieved February 2019).

The situation has indeed become dire for rhino farmer, John Hume, who is anxious to save his rhino from poaching and his farm from financial insolvency. Conservation requires large capital investment, particularly when it comes to protecting charismatic megafauna and high value species. John Hume, however, has no revenue stream; ecotourism on his farm is not an option because it would potentially endanger his rhino population by exposing them to poachers acting as tourists. In other words, more people, more risk. Hunting, too, is not an option due to regulatory frameworks, both international (CITES) and national (TOPS), which highly restricts the use and trade of 
threatened and endangered species (DEA, 2018). Lacking financial incentive and government support, game ranchers nearby are discouraged from owning rhino and taking on additional financial and security risks. When I visited John Hume he was initially excited because he thought that I was a potential investor. He soon expressed his disappointment when learning I was merely a researcher with no financial connections.

John Hume's desperate attempt to protect over 1600 rhino, however, speaks more broadly to the valuation of nonhumans and wildlife derivatives in economic terms. Moreover, it highlights concurrent commitments to replenishing gene pools, restoring biodiversity, and "nature saving" (Buscher et al., 2012: 13) through the market-driven approach of breeding wildlife.

Consumed with these thoughts as I continue my drive to the wildlife auction, I observe high concentrations of roadside signs advertising trophy hunting farms and wildlife breeders, as well as a profusion of guns and weapons supply stores. The spatial, cultural, and political character of South Africa's wildlife economy unravels before me: privately owned, electrified fences enclosing wildlife ranches (trophy hunting game farms and breeding enclosures) stretch for great distances in the countryside. I spot an occasional giraffe nibbling at leaves along the perimeter fencing of private property, "where not that long ago domesticated livestock populated those same pastures" (Spierenburg, 2019). The combination of signs, fences, and wildlife reveals South Africa's green economy and the myriad ways in which nature is marketed, produced, and enclosed for profit.

This paper advances the scope of the political economy of nature, as it exposes, describes, and evaluates the internal processes and contradictions of market-based nature production. Drawing on Harvey (1998 20012003 2014), Castree (2005 2008), Haraway (2013), Ekers and Prudham (2015), and Smith (2008), among others, this paper explains how the monetary valuation of wildlife species in South Africa's wildlife ranching industry provides a spatial and socioecological fix for wealthy landowners while at the same time cultivates ethically dubious practices and uneven consequences for nonhumans. While illustrating the specific dangers of abstracting nature into objects for profit, this paper serves as a call for a more-than-human approach to social science research that offers greater consideration to nonhuman sentience, social relations, and the ecosystems they co-constitute with humans.

\section{Observational Data: Animal lives for sale}

Stepping out of my rental car on the edge of the auction property, I realize that I must walk through a 'park' of exotic wildlife: lemurs, leopards, lions, civets, capuchins, crocodiles, white tigers, parrots, and more pace back and forth or sleep in their small enclosures. Captured crocodiles and tigers lie lazily pushed up against fencing so close they could snatch or strike innocent onlookers who talk and laugh as they stroll past the enclosures. On display just behind the 'park' in another section off the main building are a series of small bomas that enclose a diversity of wildlife: blesbok, waterbuck, nyala, impala, oryx (gemsbok), sable, eland, red buck, kudu, zebra, reedbuck, wildebeest, and giraffe. Those who will be bidding, primarily white wildlife ranchers, game farmers, and safari operators, walk a zigzag maze of lofted wooden planks to peak inside rectangular shaped viewing holes. They observe each species in the bomas below. This is done in 
relative quiet, one, to avoid stressing the wildlife, and two, because buyers are assiduously checking and noting animal body size and type, as well as the size and aesthetics of their horns. Heads nod in whispered conversation as they peer into the bomas and refer to the auction buyer's guidebook.

Peaking inside the bomas reveals the startled nature of some of the wildlife. These animals just endured an overland journey, a stressful process beginning with darting, capture (separating them from their herds and homes), loading them onto trucks, all of which ends in captivity in new and unfamiliar environs. Biermann and Anderson (2017) note what it means to be made alive, citing how individual members of specific nonhuman species are "subjected to an increasingly intensive anatomo-politics of the animal body: regular testing, transportation, enforced tranquilization, separation and recombination of social groups, imposed breeding, and the removal of offspring" (Chrulew, 2011: 148). We cannot have a serious discussion about the lives of nonhumans without ethical consideration and critically engaging the degree to which they are subjugated to human intervention. Lindsey et al. (2006; 2007), Cousins et al. (2008; 2009), Carruthers (2008), Andrew et al. (2013), Spierenburg and Brooks (2014), Mkhize (2014), and Gewald et al. (2018) provide us with an excellent starting point for critically engaging the geography of wildlife production, to which I will I be drawing from conceptually in the pages below.

At the auction nonhuman animals are either in small herds or are alone. The former may be used in the future for trophy hunting purposes but also serve the function of diversifying genetic stock and protecting particular species from inbreeding, which are challenges game managers must be particularly attuned when producing wildstock in artificially enclosed areas (personal communication and observation, 2018). The wildstock that are alone tend to be male, which depending on their size and age will become a stud breeder or international "trophy" for international clientele. These hunters are generally very affluent or have been saving up many years to live out their African safari dreams of stalking and shooting exotic "game."

After observing the nonhumans in captivity, I sit down to observe the auction.

Everyone in attendance is white. The auction begins with a

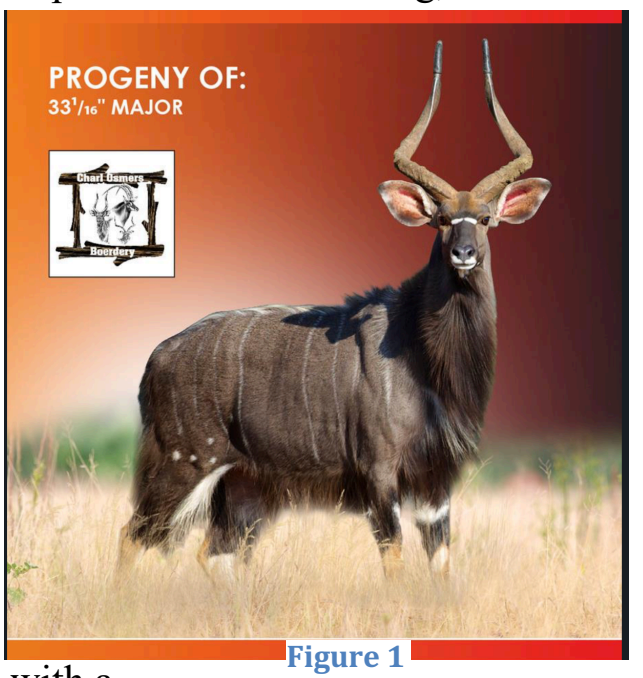
promotional video romanticizing the industry, as herds and individual nonhuman animals are photographed from different angles either in repose, kicking up dust, foraging, or being darted and measured. There are video cameras inside the bomas that allow spectators and buyers to view the wildlife in their enclosures on big screens throughout the venue at the time of bidding. Prior to the auction, industry actors are informed via email or social media with photos and adrenaline-infused music videos that showcase the size and agility of buffalo, sable, etc. that will be available for purchase (see https://www.youtube.com/watch?t=1s\&v=HQrGnk3I64s\&app=desktop for a good example). For those who are unable to physically attend the auction, they may bid remotely, either through an online app or via telephone. 
Auctioneers articulate animal genealogy to remind prospective buyers of genetic quality and trophy potential. Eluding to the sire (father) and dam (mother) of nonhumans on auction is a tactic that's used during the auction, and such information can be found in well-packaged buyers' guides touting bloodlines (Figure 1), offspring, reproductive status, horn/antler/boss measurements, and added value to already existing herds. At one auction I observed the auctioneer, when stuck at R1.45 million on an East African female buffalo, call attention to the SCI record book and state that the buffalo was worth more than a previously auctioned buffalo that brought higher bids. Despite alluding to high quality genes and physical prowess, the buffalo garnered only R1.5 million.

Interviews suggested that the buffalo was sold at a fraction of the cost it would have only a few years ago prior to the bubble. High value species, as well as color variants such as wildebeest also depreciated in value. According to one game farmer: "Record golden wildebeest once sold for 6 million rand, but now go for 15,000-40,000 rand."

This auction is rather small, comparatively speaking. It's also not highly attended, but this is more a symptom of neoliberalism and the class fissures it amplifies. Only a few years ago many South African conservationists and hunting industry advocates predicted that the breeding of what I refer to as super species, for their horn size, body, and color variation, would bubble. The increased competition of intensely breeding and producing roan, sable, bontebok, and buffalo resulted in an untenable surplus production of species leading to an almost overnight reduction in species monetary value. Leading up to the bubble, many farmers had machinations that they too would become the next big game breeder, which stimulated increased competition, market saturation, and the overproduction of color variants and high value species. According to an interview with South Africa Hunters and Game Conservation Association (SAHGCA) (2018), this amounted to nothing more than a pyramid scheme favoring those who inserted themselves into the game breeding industry first. It was a "get rich scheme" (interview, 2018) according to a number of other interviews, "motivated by greed" (personal communication, 2018) rather than conservation.

Big game breeders such as Stud Game Breeders, including South Africa's current president, Cyril Ramaphosa, profited from initially setting the prices high, in addition to profiting from the predictable market-bubble aftermath.

There were say 10 guys, Cyril Ramaphosa was one of them, who ruled that breeding thing. And they pushed up the rates on these animals to such a scale they were actually the only guys that made money. Everybody I knew then didn't make money, they lost a lot of money. They, the ten guys on top, made the prices, they set the pyramid, they made their money, and the system crashed... Now there's no value to breeding an animal for breeding purpose. Breeding animals for horn length in hunting is the new thing. It's all I do.

For some farmers new to breeding wild game, the bubble's burst meant they had to sell their land, which effectively eliminated competition and enabled larger and more established game ranches to accumulate and consolidate greater space and power in the industry (personal communication, 2018). Most importantly, this gave already 
advantaged game owners greater control over bloodlines. The consolidation of land into fewer hands is relevant to the colonial and historical progression of accumulation by dispossession (Harvey, 2003) and its more recent neoliberal economic iteration promulgating privatization and enclosure (Heynen and Robins, 2005). At the point of South Africa's democratic transition, deregulation, abolished price controls, removal of agricultural subsidies, and the abandonment of export monopolies in the agrarian sector strengthened producers and agribusiness corporations, which fueled a process of land consolidation (Spierenburg, 2018). Smaller farmers simply couldn't compete with larger scale farms that enjoyed better links to markets and clients (Spierenburg, 2019). Since 1993 the number of commercial farming units has decreased by at least $20 \%$ to 40,000 farming units in 2010 (Spierenburg, 2018). Heightened competition and deregulated price controls favor the landed class, and is reflected in the wildlife industry. It is for these reasons that auctions, particularly those with lesser-known and established players, are not in high attendance. Only certain game breeders, especially those who were able to buy approximately 15-20 years ago, are attending this particular auction.

One research participant encapsulates this development while pointing to an African buffalo:

"The people that started breeding them early, like in the 2000s, those are the guys that made millions. To give you an idea, this bull was bought for R13 million."

Indeed, those who 'got in' early profited greatly, which allowed them to expand their operation. Thaba Tholo, for example, sold Inala, a bull with a horn-span of 1.30 meters, for R168 million and used some of its money to buy a 37,000 hectare farm to breed more species (https://businesstech.co.za/news/business/137257/why-this-superbuffalo-justsold-for-r168-million/, retrieved May 2017). Thaba Tholo was established by a group of individual shareholders who bought and consolidated 20 cattle farms with the idea that it would be self-sustainable in that it could operate without any outside donations (personal communication, 2018). Success has allowed them to scale up their operation, which has fostered a number of projects including a solar farm and the production of vegetables and fish through hydroponic agriculture. More importantly, their operation contributed to the recovery of black rhinos, "augmenting populations in national parks in Tanzania, Uganda, Rwanda, and Chad" (interview Thaba Tholo, 2018). This speaks to the underlying assumption "that after in-house breeding, animals can be reintroduced, rehabilitated or rewilded somewhere around the world again (endemic or not)" (Gewald et al., 2018). Non-critical assumptions that nonhumans, such as gemsbok or even lions, should adapt to even non-endemic environments coincide with a 'sustainable use' (Gamborg \& Gjerris, 2012) approach (versus a more preservationist perspective) generally espoused amongst wildlife management and trophy hunting advocates.

In the Western tradition, conservationists and wildlife ranching practitioners strategically separate themselves from, and elevate themselves above nonhuman animals (Mullin 1999; Batavia et al., 2019). Quite simply, nonhumans are on this earth to be of service to humans. Taken a step further, however, the valuation of wildlife species entrenches a speciest, hierarchal system that elevates some nonhuman lives over others (Duffy, 2014; Lorimer, 2015). While large-scale South African wildlife ranchers may 
have the capacity to help stock protected areas both domestic and abroad, their main function, as many game breeders are quick to admit, is to provide a sustainable stock of exotic fauna for the approximately 7,000 annual international hunters that pay thousands of dollars to hunt and kill.

The taken for granted nature of this production process in relation to trophy hunting is of utmost concern, and the utilization of nonhumans for profit will guide the proceeding analysis. This chapter asks the following questions: (1) What are the perspectives, practices, and biopolitics (Foucault, 1990; Biermann and Anderson, 2017) underpinning South Africa's wildlife ranching industry and the production of nature?; and (2) How do these impact the utilization of nonhumans and their ability to live out their 'wild' lives? These questions will be addressed concurrently alongside the provision of data, which will be followed by a discussion addressing the contradictions and the degree to which nonhumans are exploited and ill-considered in an intensely neoliberalized nature.

\section{Methods and Data Collection}

Breeding high value and rare species is the backbone of the trophy hunting industry and how nonhumans are "made killable" (Gewald et al., 2018; Haraway, 2013). In South Africa's green economy, "discourses go beyond the ownership of land in an attempt to construct knowledge that portrays wildlife ranching as a good way of caring for nature and as a sustainable way of using wildlife species and habitats" (Kamuti, 2015: 146). Revealing these discourses and the way they operate on the ground necessitates that we move beyond simply observing the phenomena of trophy hunting. It requires that we observe the "hidden abodes of production" (Huber, 2017: 155), which serve to fetishize the commodification (Marx, 2011) of nature and how nonhumans are abstracted into tradable commodities (Harvey, 2007; Lorimer, 2015; Castree, 2003). To reveal the abodes of production I visited a number of wildlife ranches and game farms in South Africa, where I used a combination of qualitative and ethnographic approaches (Creswell and Tashakorri, 2007), including participatory and non-participatory observations (Clifford et al., 2016; Laurier, 2000), semi-structured interviews (Longhurst, 2003; Marshall and Rossman, 2006), unstructured interviews (Morse and Corbin, 2009), and discourse analysis (Ahmadvand, 2011; Waugh et al., 2016; Sharp, 2008; Faircough, 2003; Kamuti, 2015). In addition to interviews and observations, I analyzed discourses found on online hunting magazines, websites, and social media platforms. Furthermore, I reviewed government legal documents and state reports, pro-trophy hunting and wildlife ranching NGO reports, documentary films, conference videos, and press releases, international environmental reports, regulations and statements, and current news and relevant peer-reviewed journal articles.

Data collection formally began via identifying and meeting industry actors in early 2016 at Safari Club International's Annual Hunter's Convention. Preliminary interviews, as well as research participants in South Africa, recommended and helped put me in contact with additional research participants. To this end, this project utilized the snowballing technique (Johnson, 2014), which yielded exposure to wildlife ranches ranging in scale, success, notoriety, and power within the industry. This technique proved to be effective given the political nature of this research topic and the associated 
difficulties gaining trust and access to its social structure. Research on the ground in South Africa occurred over a six-week period between July and mid-August 2018.

Personal communications included the following actors: a) State government (Department of Environmental Affairs (DEA) and South Africa National Biodiversity Institute (SANBI)); b) Non-governmental organizations such as Endangered Wildlife Trust (EWT), Conservation Action Trust, TRAFFIC, Wildlife Ranching South Africa (WRSA), Professional Hunters Association of South Africa (PHASA), Custodians of Professional Hunting and Conservation (CPHC), Predators Breeding Association of South Africa (PBASA), and South African Hunting and Game Conservation Association (SAHGCA); and c) taxidermists, wildlife ranchers, game farmers, game reserve managers, professional hunters, international hunters, game capture teams, and veterinarians.

Participatory and non-participatory observations for this project took place primarily in the Northwest and Limpopo provinces. I selected these regions based on accessibility, trophy hunting popularity, density of farms, ranches, and auctions, and time restrictions. Field observations included wildlife auctions, hunting safaris, game captures, game farms, wildlife ranches, and game reserves. Using a digital camera I recorded and photographed practices, discourses, social relations, and nonhuman behaviors present at all observation sites. These observations bestowed greater insight into the ways nature is commodified. For example, I recorded how auctioneers at auctions speak to the bloodlines and genetics of specific species to encourage bidding and purchase. Additionally, I was able to document the wildlife industry's struggle to integrate black South Africans and the residual racial and asymmetrical power relations of apartheid on game farms and wildlife ranches. Notes were taken daily and recorded in Microsoft Word or on my digital recording device. I uploaded written notes and recordings into Nvivo that I could later triangulate with interviews and documents analysis.

Interviews took place in the homes or business offices of game ranchers, farmers, and managers. Less structured interviews took place in the cab of 4 wheel drive vehicles while surveying and learning about the landscape and wildlife management, or while accompanying hunting safaris. State interviews occurred at office buildings, cafes, and at the Botanical Gardens in the City of Tshwane (formerly Pretoria). I used a digital recorder to interview research participants to capture subtleties of communication such as pauses, inflection, emphasis, and moments of silence, which I immediately uploaded and transcribed into World for accuracy. I uploaded these transcriptions into Nvivo, which I then used to identify and analyze specific quotes and re-occurring language and themes. I arranged these discursive themes according to nodes, such as production of nature, commodification, fetishization, sustainable use, conservation, and value making. Using this software revealed the frequency of specific words and terminology and how they are used according to different roles in the wildlife economy. New categories of analysis emerged from this initial inquiry, such as wildlife management risks and internal industry conflicts, which further problematized the ecological, economic and social aspects of nature production.

As I use a narrative to problematize the commodification of nature, please note that I often cite literature that reflects my data and or findings to in which I'm in agreement.

\section{Literature Framework: Commodifying nature}


"The supposed limits to nature are actually internalized within the circulation and accumulation of capital." Seventeen Contradictions and the End of Capitalism-David Harvey (2014).

\section{"Even their sex becomes labor." Coetzee, 1999: 156 - The Lives of Animals}

The imposition of capital on nature created a second nature, one comprised of necessary legal, economic, and political rules to facilitate the continual supply of commodities for exchange and the accumulation of wealth for the bourgeoisie class (Smith, 2008) Historically, humans have appropriated nature to suit their own basic needs. Prior to the conditions of industrial capitalism, the resources found and manipulated in nature had a use-value, or rather a value directly related to cultural survival and articulation. Consciousness of these relations is the natural product of human labor and can be referred to as first nature (Smith, 2008). This consciousness constituted a unity between nature and society. Over time, however, the production of use-value shifted to exchange-value, making use-value commodities that necessitated institutions that could facilitate the exchange of goods. Separating nature from society, a fiction that there are 'things' outside the human experience, was instrumental in the process of privatizing and enclosing commonly shared social goods, including biodiversity such as land, plants, trees, and wildlife.

Bluwstein and Lund (2016: 453) argue that through processes of territorialization, conservation of biodiversity is "beyond questioning" and that control and access over land and resources for the purposes of creating conservation territories represent "frontier moments" which "evoke the establishment of new orders that eventually become settled in landscapes and minds." The privatization of nature conservation represents another frontier moment of territorialization involving state and non-state institutions that has lead to increased nature enclosures and the private accumulation of capital (Corson, 2011). "While some aspects are hard to enclose, a variety of surrogate ways can be devised to monetize and make tradable all aspects of the commons of the natural world" (Harvey, 2014: 250). The current valuation of nature, and most especially wildlife, represents the "final frontier of rapacious privatization" (Robbins and Luginbuhl, 2005: 36), one facilitating the rebundling of property rights (Ribot and Peluso, 2003) with the help of the state to private landowners and safari outfitters. Processes of dispossession of land favoring a white elite class set the stage, first and foremost, to the monetary valuation of nonhuman species (Harvey, 1998). Harvey (2003) describes four socioeconomic and political dimensions that characterize the forces driving accumulation by dispossession: Privatization, financialization, sense of crisis (loans and indebtedness), and the changing role of the state in influencing the redistribution of wealth between actors ("fiscal policies favor those with capital to invest, rather than incomes and security for the poor"). Indeed, investors are attracted to state policies that make marketable assets from nature (Fairhead et al., 2012). As over-accumulated capital seeks new investment opportunities it discovers environmental protection as a new direct and speculative opportunity for investment through the production of mechanisms like carbon trading and wildlife derivatives (Harvey 2003). 
Speculation, rather than exploitation, produces a third nature (McDermott, 2005), which refers to the potential of landforms in a given area to support specific types of wildlife communities. The alteration of the landscape is a capital investment. Herod (1997: 8) argues "the secret to capital's success lies in the ability to construct appropriate material geographies which it can use to facilitate the extraction and realization of surplus value during the accumulation process." South African speculation in wildlife ranching targets not only landforms and their potential, but also the production value of wild nonhuman species and the quality that can be wrested from them through reproductive engineering. Permitting the private ownership of nonhuman species on one's land via the Games Theft Act (1991) and the provision of a Certificate of Adequate Enclosure only opened space for greater exploitation, and is symptomatic of neoliberalizing nature. Wildlife ranching operations in South Africa, which include consumptive, non-consumptive, and the breeding of high value species, occurs within a macroeconomic framework that has promoted greater liberalization (read: neoliberalization) allowing both domestic and foreign capital to seek fresh sites for land investments (Andrew et al. 2013; Mhkize 2014).

Three modes of politics are essential to reproducing ideologies that inform neoliberalization: consensus, antipolitics, and marketing in the context of the "need for economic growth, continuous reliance on consumption, ever-increasing circulation of goods and services, intensification of labor time, and the omnipresence of commercial advertising" (Buscher, 2013: 232). Neoliberalization is not fixed, but rather a "spatiotemporally variable process" and is simultaneously a social, environmental, and global project" involving the "(re) negotiation of the boundaries between the market, the state, and civil society so that the more areas of peoples' lives are governed by an economic logic" (Castree, 2008: 143). Discourses of neoliberalism and sustainable development are intertwined, and frame environmental repair as one made possible through a "capacity for superior ecological stewardship" and "free market environmentalism" (Castree, 2008: 146). Discourses that land must be valued according to market principles reaches its apex when state authorities and wildlife practitioners decry how land is "under utilized," which triggers a higher concentration and accumulation of capital in the hands of private landowners, or results in state sanctioned green grabbing (Harvey, 1982; Spierenburg and Brooks, 2014; Fairhead et al. 2012).

Nonhumans are also viewed as being 'under utilized' (Neumann, 2015, chapter 30, Routledge handbook political ecology), which I argue is an epistemological internalization exacerbated through privatization. Wildlife authorities, conservative hunters, and state environmental agencies think of nonhumans in utilitarian terms, as resources rather than kin (Robbins, 2011; Coetzee, 2016; Kimmerer, 2013). Socially constructing a hierarchy, where humans are above nonhumans, serves to unlock the latter's economic potential (Emel et al., 2002; Lorimer, 2015). Viewed in this regard, nonhumans can be used to drive development policies and projects so long as the resources are produced and harvested sustainably. Under this regime, unfortunately, 'development' is oftentimes equated solely with jobs created and hardly any attention is paid to the nature of the jobs on offer to the poor (many of which are temporary or 'unskilled'), or how remuneration compares to the benefits from previous livelihood strategies (Spierenburg and Brooks, 2014: 160; Li, 2011).

The commodification of nature in South Africa occurred more pragmatically in 
response to environmental complications such as drought in the 1970s and 1980s, and reduced environmental and financial regulations (Buscher and Ramutsindela, 2016). A body of evidence emerged during the 1990s indicating that structural adjustment exacerbated environmental degradation and biodiversity loss through reductions in public spending on environmental institutions and government services, and by increasing direct dependence on natural resources for subsistence (McDonald, 2010). According to McDonald (2010), with support from the United Nations Environmental Program and the Global Environmental Facility, trophy hunting, bioprospecting, and ecotourism became the manifestation of a commoditized nature reoriented to serve elite and corporate interests but that would, under the rhetoric of 'community-based conservation' (CBC) also provide a 'profit' for local communities" (McAfee 1999, Hayden 2003, MacDonald 2010). Cherry picking aside, $\mathrm{CBC}$ has not generated sustainable socioeconomic outcomes for the rural poor (Kepe et al., 2005.); rather it has foisted Western values and systems on local communities thus enclosing the public good. Coinciding with these neoliberal developments in international conservation were ecological discourses linking deforestation and wildlife habitat loss due to uncontrolled industrialization, modernization, urbanization, and poverty (Escobar, 1995; Broch-Due and Schroeder, 2010). Blaming the poor for poor land management was nothing new, nor placing the burden of responsibility on the poor to protect the global commons. In a cruel twist of fate, the best way to "develop" the poor in the Global South was through a market-based conservation displacing millions of subsistence farmers and transforming them into wage laborers and "conservation refugees" (Dowie, 2009: xxii).

Hegemonic discourses of sustainable development legitimize the contradiction that capitalism can solve problems of its own creation (Brockington and Duffy, 2011). As signatories to international sustainable development (Sustainability Development Goals (SDGs)) and biodiversity goals and initiatives (Convention on Biological Diversity (CBD)), South Africa understands trophy hunting's associated economic and environmental services to be a viable strategy in the green economy (DEA, 2018). The Green Economy has risen to institutional prominence and is positioned to supersede sustainable development as the hegemonic discourse in global environmental governance (Brand, 2012). One major problem with the CBD is that "it codifies a dominant perspective of nature as capital through its emphasis on sustainable use initiatives that, when translated into practice, means the use of in situ biodiversity to realize profit through the conversion of use value to exchange value" (MacDonald, 2010).

Collard and Dempsey (2013: 2) examined the value of nature through Ahmed's "conception of bodily orientation," and mapped out five categories for conceptualizing "how living bodies/natures can be oriented relative to capitalist social relations." Each of these categories has significant relevance to South Africa's green economy, particularly the means of manipulating nonhumans for financial profit. The first are what capital sees directly as input (officially valued) including both free and unfree labor, such as lively commodities (i.e., females capable of reproducing, farming animals value according to age, gender, and breed) (Haraway, 2013; Barua, 2016; Collard and Dempsey, 2013). Lively commodities are "possibly more akin to unfree laborers" (Hribal, 2003) who are bought and sold as commodities and whose labors belong to their owner (Collard and Dempsey, 2013). According to Collard (2014: 153), "a lively commodity that remains alive... has two lives that are intertwined but are not reducible to the other: a wild life 
and a commodity life." Collard (2014: 153) suggests that an animal's commodity life depends on its wild life even as it diminishes it profoundly, reducing it to what Haraway (2013) calls an undead thing. " Capital seeks a relative surplus of reserve laborers/inputs/commodities (category 2), such as entities with future exchange value like genetic resources and game that are available for harvest (Collard and Dempsey, 2013). Some nonhumans count towards capitalist production but are unwaged/unpriced, such as pregnant game that cannot be hunted (category 3), while others, the outcast surplus (category 4), are of no interest to capital at all. Lastly, nonhumans deemed to endanger capitalist accumulation (category 5), such as invasive species and predators, are seen as "threats" to other species of greater value. Problem animals are assigned a very inexpensive monetary value because landowners simply don't want them, and this is reflected in policy (Dickson et al., 2009). For example, caracals and jackals are unprotected on South Africa's Threatened or Protected Species List (TOPS) (Cousins et al., 2010), whereas other species of greater value, such as kudu, sable, and buffalo, have greater legislative and physical protections.

Physical enclosures of wildlife represent another push towards exchange value. "Fencing animals and reconfiguring the division of rights and responsibilities in nature to individuate the flow of value from biotic systems facilitates accumulation and fits neatly into neoliberal economic culture" (Robbins and Luginbuhl, 2005: 31). While the state's role as a driver of conservation has been rolled back, it intervenes to regulate and facilitate markets (Igoe and Brockington, 2007; Castree, 2008) that help to develop more positive attitudes towards their activities (MacDonald, 2010, 2011). Fairhead et al. (2012: 242) calls this the "the economy of repair," one that aptly reflects a larger transformation in which the "discourse of global ecology has accommodated an ontology of natural capital, recasting environmental problems as the result of market failures rather than specific outcomes of market-based ideologies, practices and relations" (McAfee, 1999).

However, "neoliberalization produces predominantly environmentally undesirable and socially regressive political and economic outcomes" (Heynen et al. 2007). A great deal of research has been done recently on the proliferation of game farms in South Africa (Spierenberg and Wels, Brandt, Josefsson, Kamuti, Snijders, Mkhize, 2013), which argued that the socio-spatial dynamics of the wildlife industry, driven by capitalist imperatives related to the commodified production of nature and 'wilderness', warrant both in-depth investigation and contextualization in terms of broader processes of agrarian change, and point to contestations of land rights and property ownership. These broader processes have real life consequences for not only humans, but also the nonhuman species that are now enclosed on wildlife ranches and unable to voice their dissent.

\section{Wildlife Ranching Background}

There are approximately 8,979 privately owned wildlife ranches in South Africa (Taylor et al., 2016), which covers $17 \%$ of all South African land and represents $80 \%$ of protected areas in the country (Van der Merwe and Saayman, 2005). Wildlife ranching, for the purposes of this paper, focuses more specifically on intensive breeding and live sales in relation to trophy hunting, biltong hunting, and game meat production. These ranches vary in terms of scale, breeding intensity, management, and economic 
diversification strategies. More successful farmers are able to control the "value chain" (interview game farmer, 2018), as they do a mixture of all wildlife ranching activities, including producing and harvesting their own animal feed on nearby plots of privatelyowned land. The most sustainable operations are typically those that control and maintain access to the supply chain. Some game farmers mix cattle and game ranching into their enterprise, which acts as a buffer against lulls in international hunting tourism and ecotourism. Game and mixed farming has proven to provide conservation benefits to wildlife and even rescued particular species from the brink of extinction, such as bontebok (Cousins et al., 2008), cape mountain zebra (WRSA, 2019), and white rhino. There are disputes regarding the number of wild species now roaming these farms, as the Professional Hunting Association of South Africa (PHASA) frequently touts that there are now 24 million animals in South Africa on account of wildlife ranching. Endangered Wildlife Trust (EWT) believes that the number may be inflated according to data collection methodology (personal communication with EWT, 2018) and may resemble something closer to 10 million. This number is hardly negligible, however, considering that there were approximately half a million wild animals in the country as late as 1964 due to overhunting and land policies that favored livestock production.

"Farming the wild" (Carruthers, 2008) in South Africa is driven in large part by the largest trophy hunting industry on the continent that generates considerable revenues from hunting permits and lodging fees (Lindsey et al., 2006). Industry advocates and practitioners such as Wildlife Ranching South Africa (WRSA) and the Professional Hunter's Association of South Africa (PHASA), and a number of state and non-state conservationists regard trophy-hunting tourism on wildlife ranches as 'low impact-high reward', as they potentially generate revenue in regions generally unsafe, isolated, economically and politically marginalized, and environmentally unsuitable to ecotourism, grazing livestock, or food production.

Wildlife ranchers breed high value species such as buffalo, bontebok, and roan for large profits. A number of research participants explained that before breeding became big business, individual animals with the biggest horns were trophy hunted before they could spread their genes. Industry advocates realized that this was not sustainable. Smaller horn sizes, coupled with no replacement animals, as well as political, economic and environmental shocks in the 1980s and early 1990s, meant that farmers could no longer cover the costs of maintaining their farms. Breeding animals offered a sustainable alternative that would offset shocks and guarantee future business. Breeding the largest horns and largest bodies restocks local species to their former pre-colonial glory, draws international "inch-chasing" (interview, 2018) trophy hunters, and diversifies their livelihood strategies in contending drought, climate change, and increased regional hunting competition with countries such as Namibia and Botswana. Most recently Botswana re-opened its hunting concessions following a national dialogue amongst practitioners, landowners, and rural communities. Botswana conservation authorities seek greater inclusion through community natural resource management, which South Africa still struggles to accomplish due to poor government support and implementation of land reform policies. While international trophy hunters carefully select their destinations based on diversity of species and their financial and ecological contributions to conservation, community development, albeit arguably paternalistic, remains an important aspect to their safari experience. As land reform fallows, wildlife ranching 
advocates point to the green economy as the panacea for environmental and economic repair.

Wildlife ranching is thus framed as a win-win scenario, entailing minimal footprint and upfront costs while simultaneously yielding considerable remunerations with the growth potential for offshoot economies. In South Africa's case, these economies are discursively and materially situated in the green economy, which also includes fencing taxidermy, translocation, game capture and sales. Trophy hunting, despite over 130, 000 animals hunted in a year, makes up a very small part of wildlife ranching, generating approximately 2 billion rand per year, and makes up about $2 \%$ of tourism (TREES, 2017). While econ ${ }^{2}$ omic contributions from trophy hunting may appear small, it drives the game breeding industry and hence the "green" wildlife economy principle.

Leading conservationists believe the ranching sector should be expanded "sustainably" as it helps economically stimulate other sectors such as transportation and agriculture (Saayman et al., 2018) and contributes financially to national anti-poaching and conservation efforts and initiatives. The South African Department of Environmental Affairs (DEA), working with private and public institutions and organizations have written environmental and regulatory policies in support of the green economy, encouraging fair and equal access to and sustainable utilization of natural resources and wildlife derivatives with the goal of meeting the economic, cultural, environmental, and dietary needs of rural and historically marginalized communities (https://environment.gov.za/. Provincial and national policies are also embedded in international strategies such as the Partnership for Action on Green Economy (PAGE), to which South Africa is one of 18 countries committed to aligning with the Paris Agreement and 2030 Sustainable Development Goals (SDGs) (https://www.un-page.org, retrieved May 2019). The South African government seeks to improve socioeconomic and environmental outcomes through private-public partnerships in a number of industries, including resource conservation and management.

The current umbrella term for meeting the needs of historically disadvantaged communities used in South Africa's political discourse is transformation. An example of such efforts can be found with the elite-breeding group, Stud Game Breeders, who in 2014 started a bursary program by holding an auction to raise money to support eight students entry into the Game Ranch Management program at Tshwane University of Technology. Speaking at a wildlife auction, Cyril Ramaphosa, current president and one of six game farmers comprising Stud Game Breeders, was quoted as saying (before an audience of white farmers), "Transformation is critical to the sustained success of the game breeding industry, and educational efforts like this will be essential" (https://studgamebreeders.co.za/2016/05/06/special-auction-helps-propel-sa-gameindustry-transformation/, retrieved May 2019). The president of WRSA, too, Tebogo Mogashoa, who is a black South African, speaks adamantly about socioeconomic transformation and the transformation of a very white hunting industry in the context of a history of institutionalized racism. According to Kamuti (2015:155), "game farming is a capital intensive venture that makes it difficult for new entrants to penetrate the sector

\footnotetext{
${ }^{2}$ While rural communities may benefit at a small scale from building mending fences year round, making their employment fit within "green" economy, security company owners and management profit disproportionately and are a significant fixture at wildlife auctions.
} 
and therefore, by implication, game farming becomes a class issue." Access to land, markets, and financial investment, however, are not simply class issues but rather legacies of racist colonial and apartheid policies. As a majority of black South Africans remain without title or access to land, wildlife ranching remains uneven economically and spatially according to race. Indeed, surveying those in attendance at the auction, I noticed all the attendees were white. I listened to the auctioneer mix English and Afrikaans over the loudspeaker. Aside from a handful of very resourceful and powerful black wildlife farmers, private wildlife ranching remains overwhelmingly white.

Wildlife Ranching South Africa (WRSA) knows that it has a race problem, and that the future of the industry depends on its ability to repair relations with black South Africans (multiple interviews). Well-intentioned words and sentiment up until this point, however, have not delivered on land reform promises or improved livelihoods for rural South Africans (McCusker et al., 2015), and amount to more political theater than anything real. Small bursaries attempt to repair the injustices of the past, but operate from and embed a utilitarian sustainable use approach that encloses the commons and monetizes the death of nonhuman animals.

Biermann and Anderson (2017: 3) note how "bodies and bloodlines are not the only things "made to live" in breeding projects; particular social values, structures, and subjectivities are reinforced alongside and through wildlife." More succinctly, technological and scientific practice is hardly objective and disembodied (Rose, 1997; Aitken and Valentine, 2006) from inherited cultural values and ways of knowing and interpreting the world. The power of these particular values and subjectivities appear to occur apolitically and without origin. In this sense, the fetishization and commoditization of nature occurs discursively in an ontological and epistemological struggle over the meanings and categorizations humans utilize and ascribe to terms and concepts such as natural, community, produce, or conservation. These meanings play a significant role in terms of producing and maintaining cultural identity and historical memory, and extend to power over natural resources and the lives of nonhumans.

This paper argues that neoliberal market principles, which drive the commodification, valuation, and privatization of wildlife, come with an assortment of problems that normalize the objectification and abstraction of nonhuman lives. The neoliberalized conservation model depends on the trading of wildlife commodities, which opens new opportunities to exploit, privatize, and profit from alienating nonhuman labor (Simon, 2016). The ability for nonhuman animals to realize their "wildness" is diminished, and their lives are frequently cut short. The private model encourages greater control and a constant search for transforming wild animals into capital. This research project shows that nonhumans in the wildlife ranching industry are not only "made to live," but also live to die for profit.

From birth to death nonhumans must navigate "natural" fluctuations (according to research participants) in the marketplace. However, the lives of nonhumans, before birth and after death, are also not invulnerable to the capriciousness of capitalist valuation, transformation, and accumulation. Moreover, the very life of nonhumans that are bred for profit depends upon a process of speculation whereby industry actors imagine the physical attributes it will manifest through genetic composition. This way of thinking resembles a third nature (McDermott, 2005) not so much at the landscape level, but at the individual biological scale. In other words, wildlife ranchers take third nature a step 
further, not only asking 'what is the ideal habitat?' and 'what is its potential?' for capitalist accumulation, but more specifically, 'what is the ideal animal?' and 'what is its genetic potential?' for economic gain. Perceptions underpinning the speculative fervor of genetic composition in relationship to nonhuman lives are presented and evaluated in the sections below.

\section{Data and Discussion}

\section{Intensive and extensive breeding}

Breeding wildlife demands a great deal of human intervention and manipulation. Breeding of high priced wildlife requires that nonhuman animals be put into smaller enclosed camps (10-100 acres) called intensive areas for a period of approximately five years depending on species. They first go through a period of approximately one year to fifteen months at which point they're weaned. The males (bulls, rams) are then put into camp together but are kept separate from any females so as to reduce the stress that comes with competition. Undue stress may cause aesthetically disagreeable irregular ring spacing on the horns; any imperfection reduces the commercial value of an individual species. When approximately three to three-and-a-half years of age, ranchers evaluate the males and decide if they will be kept as stud breeders and will thus give their reproductive lives to inseminating valued female stock, or will be better suited for trophies. Importance is also placed on selecting the right females for breeding, which generates substantial revenue for ranchers. In general, breeding bulls will be moved into a camp with a harem, while the ones selected to be trophies are moved to an extensive area, which is larger in size (up to 40,000 hectares) but also enclosed by a fence. On these extensive areas 'fair chase' trophy hunting takes place on foot (stalk and shoot with rifle, which oftentimes involves driving within general proximity of the identified "harvest" before stalking occurs), from the flatbed of a bakkie (for beginners, physically disabled, or hunters without a lot of time), and from a sedentary position (bow hunters hide inside a hovel or behind a "blind" near an artificial watering hole and salt lick to bait wildlife such as buffalo).

On the extensive enclosures farmers will clear areas and remove brush and trees that may be toxic or hinder access to quality grazing (personal communication and observation, 2018). In this sense, skillful game managers not only read and determine quality and potential of wildlife; they must meet the challenges of reading the ecological landscape as well (participatory observations). They operate according to an ecological equilibrium approach mostly due to legally required fencing, which ultimately determines the sustainable "harvest" of particular species. Off-take percentage ranges from $1-10 \%$ depending on species ethology, predation, market valuation, and climate variation and shocks. Depending on available funds and species type, farmers will provide supplemental feed in the intensive areas particularly during long periods of drought.

The "quality" of animal depends upon the skill of the farmer, and his (it's men, not women that do this work; not only is this industry white, but it's also very male) ability to identify quality grazing. Farmers rotate plots of land for grazing, choosing to let adjacent land plots lay fallow. Once one plot of land is no longer able to provide quality grazing, they are moved to an adjacent fenced off area. Wildlife in intensive breeding 
enclosures is provided quality feed, medicine, veterinary care, and water. Buffalo, sable, wildebeest, etc. in the intensive areas enjoy predator-free grazing opportunities (excluding leopards or caracals who are known to circumvent security fences). In other words, while able to socialize and learn how to forage and identify quality grazing, captive bred animals are rarely tested; they do not have to work very hard to survive against predation or seasonal variation. Consequently, there is debate regarding if intensively bred species, particularly color variants (impala, wildebeest, springbok), are wild enough to survive in the veld without supplemental feed during harsh winters or prolonged drought. One reason some farmers choose wildlife over more traditional livestock is because cattle are not as resilient or durable as wildlife. It simply makes more financial sense for farmers to raise wild species whose survival chances are much greater during climatic shocks than their domestic livestock counterparts. This is idea is hardly new, for in a conference in 1961, Mr. Van Vuren stated the following:

"If farmers would know that fields are more profit-yielding by stocking wild animals alongside farm animals; because they need less attention; because they need not to be dipped, fed, or looked after; because annually a percentage can be sold alive, for breeding purposes, or as meat carcasses; then there would be many landowners who would consider taking up wildlife in their farm business."

There is no conclusive scientific data that indicates that intensely bred wildstock (wild livestock) are not wild enough to adapt to new and harsh environs without human intervention, yet skepticism remains. One game manager in particular acknowledged that certain species carrying the recessive gene may be not be as fit for survival: "I think the black impala is not the same as the normal impala. It's a little bit weaker I want to say." From a genetic perspective, the intensive breeding of color variants is inbreeding as it "seeks to reproduce the recessive alleles, which leads to reduced heterozygosis and the loss of rare alleles that provide adaptive potential to climate change" (National Dialogue Integrated Report on Color Variants, 2016). Adaptability may depend on the overall population size, but this process overall distorts the natural evolutionary process (EWT, 2016) and places risks on biodiversity that are not entirely understood. While color variants may occur naturally, their selection is unnatural. A number of hunting NGOs are concerned about the detrimental effects of color variants on biodiversity, yet Wildlife Ranching South Africa (WRSA) sees absolutely nothing wrong breeding them (NDIR, 2016).

As black impala have been photographed in Kruger National Park, their coloration indicates a natural recessive gene that fades away in free roaming areas due to the dominance of normal color impala (Furstenburg, 2016). The game industry intensely produces these naturally occurring species in accordance to a safety in numbers approach that shields their distinctive color from predation.

The following quote epitomizes industry discourse regarding the naturalness of captive-bred wildlife:

"That's where they naturally occurred. That's where they come from. It's not something that is artificially created and we breeded (bred) with them. 
It's something... white impalas, there's a property close to here, white impalas were there, but predators go for them because they're different. But if there's more of them then it's different. If there's a lot of white blesbok it's completely different but if there's only one in the open area there, what predators does is they don't run into a herd and catch the first one they get. They identify the animal and go for the animal. That's the one. So they zoom down on that specific animal. So if there's one that's a different color and all of them is the other color, it's an easy one to pick. If the numbers were more...but now that's what we did with the game farming you know. We took the ones we got outside in nature; black impala in Kruger that people took pictures of. So it's something that naturally occurred. We took those and started to breed with those and now we have bigger numbers and they're running on the open properties (extensive areas) and because of their larger numbers they survive. They're more adapted."

It's important to note the contradictory elements of this quote in the context of industry discourse, which vehemently claims its commitment to restoring biodiversity to its precolonial era. While increasing color variants may provide a richer diversity of nonhumans to "harvest" for domestic and international hunters, their conservation value, beyond capital accumulation, remains unclear if not dubious. They have failed to explain what precisely is "natural" about intensively producing species that evolutionary processes did not permit. This type of evolutionary interventionism ignores historically natural biological processes - processes where nonhumans and their environments are inherently free from capitalist confinement and configuration. Using the word "natural" to describe the occurrence of color variants that heretofore did not exist in great number suggests a political linguistic choice meant to green wash and reinforce the utilization of nonhumans for profit.

In an additional response to industry critique, naturalness is insisted upon:

"We often here the term "laboratory conservation" or laboratory this or that, but it's not that at all, it's not a man made thing. The color variants were in nature. The black impala, the white lions of Timbavati, the golden oryx in Namibia. All that man has done is seen it, said hey there's a value to it, let's breed up the numbers, and yes, let's breed this golden wildebeest. The market wants this color wildebeest. So if you get a cow of that color and a bull of that color of trophy size, big trophy size, let's selectively breed for that. It's by no means what I would call artificial. It's not a manipulation."

The oryx, or gemsbok, while indigenous to the Kalahari of Namibia and parts of northwestern South Africa, have been introduced to habitat outside their natural distribution range in places such as Limpopo. Indeed, gemsboks are very adaptable, but living outside their typical environment makes them extra-limital species and contradicts conservation's core ecological principles. If the purpose of conservation policy is to 
restore ecological integrity and biodiversity, then we should assume they'd disallow gemsbok and their color variants from roaming non-historical ranges. We would also assume there'd be greater concern for the potential ecological impacts of introducing extra-limital species. As wildlife ranchers will reference their work as wildlife management, they are indeed manipulating nature, and by default, the surrounding environment to suit their economic goals.

One research participant corrected himself upon using the word "produce" in regards to wildlife ranching.

"When I started hunting sables with clients, the average sable was 36, 37 inches that the clients hunted. And because we are doing what we are doing, we are hunting now 44 inches sables, which was say six years ago, which was really a breeding quality animal. The quality of the animals we are producing out of South Africa, can't say produce, I mean it's not a factory, it's natural you know. But of what we are doing, the management behind it, the quality is increasing."

In this instance a human interventionist process of an economized and produced nature is equated with one biologically given through unassisted nonhuman reproduction. We know, however, that industry actors operate from a nature/society divide placing humans outside of nature, meaning that equating the breeding of wildlife to a natural process contradicts their inception point. The lived experience of nonhumans, in this sense, can be attributed to powerful industry actors driving discourses that naturalize the denaturalization of a capitalist nature.

Denaturalization has been used slightly different in the past amongst "nature skeptical" (Castree, 2005) geographers. Denaturalization generally refers to the ways in which cultural values have diminished the naturalness of humans, thus making them invisible on the physical landscape. This notion of a pristine wilderness coincided with capital, urbanization, and the nostalgia for a nature unsullied by human industrialization (Foster, 2008). Wealthy landowners paid artists to dream up landscapes portraying an immaculate countryside that over time served to feed the colonial imagination of a nature separate from human society. Assimilation of this perspective was "passed all the way down" (Castree, 2005) and it is in this sense that nature is a social construct. By removing humans from the landscape nature is sanitized, or rather denaturalized. Denaturalization, for the purposes of this paper, expands upon this notion, operationalizing how humans reduce the voluntary movement and natural reproduction processes of nonhumans while discursively claiming their offspring and subsequent mixed social groupings thereafter are of natural occurrence. Denaturalizing processes are integral to normalizing the network of institutions, organizations, and technologies that underpin second nature (Smith, 2008). The wildlife industry insists on having it both ways, where humans are denaturalized on the landscape, yet they are a natural part of producing nature.

Discursive contradictions meet at the interface of disorientated meanings and the power relations that lend them credence. It is believed that some wildlife ranchers use conservation as a guise for profit. One game manager puts it this way: 
Interviewee: Now there are 15,000 sable. Then you drive through Karoo and you see sable, and think maybe this wasn't such a good idea. Because they don't occur there naturally.

\section{Interviewer: Like gemsbok from Namibia in Limpopo?}

Interviewee: It's a good story for sable, but not necessarily a good story for conservation. Conservation, the word, has been raped. Every second guy is a conservationist. Every guy that gives a monkey an orange is a conservationist.

This sentiment was echoed in a number of interviews. One NGO in particular expressed that industry actors operate according to varied definitions of conservation based on agenda. Conservation's role in environmental sustainability and economic development has shifted a number of times over the past few decades, from a fortress conservation (Stevens and Dean, 1997; Brockington, 2002) seeking to protect nature from the upheaval of human development to an inclusive community-based model meant to provide socioeconomic benefits through "community" management of natural resources (Kepe, 2008; Cundhill, 2010) South Africa's most recent iteration lessens the role of the state and places the onus of economic and environmental sustainability onto the private sector, operating under the logic that private landowners have the ability and skills to more efficiently manage natural resources (Ramutsindela and Shabangu, 2013). This neoliberal shift allowed them entry into national conversations that influence wildlife management policy today (Cousins et al., 2010). Initial conversations between industry advocates and the Department of Environmental Affairs (DEA) were intended to improve the treatment of animals, define fair chase, and ensure that hunting practices did not compromise the long-term viability of species and ecosystems (Cousins et al., 2010). These conversations led to the development of Threatened and Protected Species (TOPS) regulations (Cousins et al., 2010), which were necessary particularly following the more decisive economic policy that encouraged farmers to shift from domestic agricultural production to wildlife game farming, and where regulation lagged drastically behind legislation.

Many wildlife ranchers have backgrounds in agriculture and see the production and utilization of wildlife not dissimilarly from domestic livestock (personal communications, 2018). This is a frequent critique amongst game farmers who have been in this industry for longer periods of time and who set themselves apart as being drawn into the industry by a purer set of conservationist principles. They argue that it's the unethical business practices of former agriculture-minded landowners that ruin the industry's reputation (personal communication, game manager, 2018). Those who have historically abided by the principles of fair chase and sustainable utilization have now been unfairly burdened with greater bureaucracy and regulation because of a small minority of bad actors co-opting conservation for economic gain.

\section{Genetic Composition}

Nonhuman lives are controlled and manipulated from conception and through birth, breeding, cross breeding, DNA testing and genetic intervention (Gewald et al, 
2018)). It's a highly scientific, technological process that requires that the reproductive capacities of females be appropriated to achieve supreme genetic composition. Passing on the best genetics generally translates into large profits for wildlife ranchers, who are then able to reinvest their profits into scaling up their operations. Achieving "supreme genetic condition" requires a highly scientific process that reduces wildlife to biological breeding material.

"We salute Sam and his daughters with this outstanding achievement and quality stamp of approval as some of the best and most respected breeding material in South Africa. We were therefore very fortunate to become owners of the bull Duke, a young giant, bred from the Gemsbok/Stamper genetic pool combined with the bull Piet. This excellent genetic makeup as manifested in Duke was scientifically integrated and introduced on carefully selected cows: daughters of Sam as well as granddaughters of Sam born to our well known Western Zambian bull Assegai (47 2/8”) brother to exceptional bulls, namely Charlie; Tsunami; Black Jack and Zambezi. The supreme genetic composition derived from Sam with added value from Assegai and then matched with Duke should surely make it one of the most diverse and sought after combinations brought together in recent times." (https://www.cottondale.co.za/genetic-composition.html, retrieved October 2018)

The boastful discourse above acts at multiple levels: It's an invitation to greater investment opportunities, and is meant to stimulate increased production and sales to other game breeders and safari outfitters looking for quality trophy specimens. Secondly, declarations of genetic success draw positive attention and create greater recognition in the industry. Conversations with a number of smaller scale farmers revealed the importance of building a reputation for producing high quality "game" in a wellestablished breeding industry. Carving out a reputation in an industry dominated by an elite may dissuade newcomers, who are at a disadvantage when competing against betterknown breeders and for international investment. Kamuti's important research (2015: 155) concluded that "game farming is a capital intensive venture that makes it difficult for new entrants to penetrate the sector and therefore, by implication, game farming becomes a class issue."

One very successful game farmer and game breeder specializing in African buffalo recently sold some of his buffalo to the emir of Qatar. According to him, the "king, who is the sixth wealthiest guy in the world" (personal communication, 2018), bought 40,000 hectares of land nearby, which he plans to populate with about 200 buffalo. The emir, Sheikh al-Thani, has no interest in breeding these buffalo for re-sale. Instead, this new game reserve will be used for recreation, for the king and "his friends to just shoot the buffalo or whatever" (personal communication, 2018). This project increases wildlife habitat and brings jobs, so "why wouldn't it be a good thing? If that's the case, then why should it matter if the land is owned by a foreigner or not? You tell me."

It's this kind of response that green washes the ongoing "dual processes of accumulation and dispossession" (Mearns et al., 2012). It reveals a great deal of privilege 
and lack of historical and cultural understanding, and highlights the economic logics underpinning privatized conservation. In other words, if there are at least some measureable economic and environmental benefits then the structure supporting this particular land use does not warrant amelioration. Industry actors may also point to state attempts to attract foreign capital to legitimize its claims and decision-making. National and international investors are encouraged by state policies that make available assets, including land and other marketable resources (Leach et al., 2012; Harvey, 2007). For example, the South African government welcomed the Sheikh al-Thani in 2017 to strengthen economic ties and investments in technology, agriculture, tourism, and Black Economic Enterprises (BEE) (https://www.iol.co.za/news/opinion/proof-that-sa-has-themagic-8757598, retrieved December 2018). While the purchase of land and wildlife assets for the wealthy emir helps repair the problem of overaccumulated capital it does not resolve issues of uneven development and land ownership in South Africa. For a country seeking to overcome legacies of apartheid, the neoliberalizing nature of foreign land investment and acquisition deserve greater critique.

The buffalo that the wildlife rancher points to are especially large in size. He says they're going to move them to be with Horison. "Horison is the biggest buffalo in the world. It's a breeding project and (name of breeder) is part owner of that. The females are going to run with that buffalo." He points to one female buffalo, which he says sold for 600,000 rand $(\$ 53,000)$, and then points to another, the "calf of Horizon":

"You would get a million and a half, two million. She's out of a very good bloodline and she will be coupled with that bull something very special."

Horizon is thought to be the most expensive buffalo in South Africa, as he was valued for as much as R176 million in February 2016.

I would argue that the game manager casually fetishizes the lives of nonhumans and reduces them to human profit and pleasure. The quote too reflects the conservation through utilization model generally touted by industry actors, as found below:

...um you know I'll be completely honest. Our mindset and our approach of that is game and animals are animals, they produce to be utilized by man, and provided that what you do you do in a responsible way, you may utilize. So you would very seldom get the question being asked around the value of the life of an animal. If you eat meat you have to kill something to eat. There's people very often think you go buy food in the supermarket, you go buy meat there, it gets produced in a different way. It does not. There's an animal that was killed to produce that meat, whatever meat that is.

There are differences between hunting for sport and hunting for trophies, but the shared commonality is that animals exist to be utilized by humans. In the scenario described above about the emir and the buffalo, we cannot ignore how the latter performs a utilitarian function. The life of a buffalo that is simply produced and supplied for the enjoyment of a wealthy government official to shoot amongst privileged friends goes 
unanalyzed. Even if the individual nonhuman will at some point get to graze on an extensive yet enclosed area, it will soon be made dead for fun.

The deadly effects of color variation

"If my grandfather knew what I paid for this black impala he'll slit my throat. They say a black impala was a crossbreed, they doesn't want it on the farm. Two years ago it went for half million to 850,000 rand for one and now they are about 5,000 because the market is, there's too much in the market."

Color variants, initially "unwanted" and mere "crossbreeds," were essentially of no value. In response to international competition and market demand, however, color variants became the boutique of biodiversity --- an expensive collectors item in a niche market for affluent ranchers and international trophy hunters. Indeed, new types of grand slams have emerged to cater to trophy hunters that want to harvest color variants. For example, a 7-day grand slam package might include a blue, golden, and kings wildebeest for approximately US\$13,800 (driesvissersafaris.com, retrieved January 2019). For trophy hunters that opt not to go with a packaged hunt, but instead elect to shoot nonhuman animals a la carte, the cost to hunt a common blue wildebeest is generally US\$1, 000. In contrast, a golden wildebeest will cost over US\$5,000. A 7-day impala grand slam includes a normal, black, saddleback, and white flank for approximately US $\$ 10,000$. The cost of hunting an individual impala generally cost less than US\$400. Color variants were more expensive only a few years ago prior to the bubble, which some game ranchers say is a good thing because local South Africans can now afford to hunt them. The degree to which South Africans are hunting color variants remains inconclusive, yet it speaks to the necessity of wildlife rancher ability to diversify the financial and fetish profile of desired clientele.

"Some people, like with black impala, they are worth almost nothing now. If one dies, it's not really a big loss anymore. So people tend to not take care of them quite well anymore..."

Crossbreeding color variants for profit has resulted in the production of nonhumans that are resolved through the value chain. The commodity form of nonhumans shift accordingly, as demonstrated in the quote below.

"What happens with the color variants of impala, with the black impala you have 50 females and black impala ram. Then you breed that ram with the normal females and you get splits out of them. Now the little rams that comes out the split, still looks like the normal one, but now carries the black gene. Then you have to put a black male on that female again and then you might get a few black lambs out in your second or third year. So those young rams they will get culled, the ones that doesn't come out black, they will get culled, the meat will be sold, it will be used. So yeah 
that type of culling happens a lot." (Interview with Bona Bona game manager, 2018)

Chrulew (2011: 141) explains that the "tragic irony" of captive breeding and assisted reproduction is that making live (emphasis original text) indeed leads to death, as the population eventually "'exceeds the accepted sphere of zoological care"" and "'the lives of numerous individuals are consigned to genetic irrelevance or collateral damage, tossed overboard the ark" (150)_let die or killed (Biermann and Anderson, 2017). Breeding wildstock operates from the position that meat sales alleviate overproduction and can potentially provide a cheaper protein source for rural communities. Culling, when situated in Malthusian and poverty discourses, provides a convenient justification for breeding surplus animals, for "nothing goes to waste" (personal communication, 2016). To avoid becoming unvalued waste, the labor of an individual nonhuman, previously produced to suit a higher economic purpose, is recirculated and accumulated by capital. In essence, the life of a nonhuman animal is transformed into an entirely different commodity once it becomes clear it cannot carry out its genetic potential. The value of the animal, once based on its labor and liveliness, is now realized in its death. In summary, nonhumans are economically re-circulated, as they are culled, carved up, transported, and sold on the local meat market.

This process reveals the degree to which wildlife is reduced to domestic livestock to be consumed, reflecting more an agricultural operation than one of biological conservation. Despite the fact that the act of culling is a task that brings no one pleasure (personal communication, 2018), it remains a natural byproduct of breeding wildstock. Subsequently, some animal lives, particularly those with the wrong skin color, are worth less and die sooner than others.

Color, however, is not the only characteristic that determines an animal's value. It is measured quite literally in horn/boss/tusk size. One taxidermist, who's also a professional hunter, game farmer, and safari operator, noted how the quality of certain species has changed over time due to market demand for trophies.

"Yes. Especially species big in breeding, sable, buffalo and roan. These three, the horn lengths got exceptionally bigger. Say a 38-inch sable a few years ago would have been considered huge. Now it's considered small. Where to enter a sable into record book it was 44 inches. Clients shooting up to 48 inches. Breeding bulls these days is 52 to 53 inches. Everything changed with the breeding of animals when it comes to horns. Breeding animals for horn length in hunting is the new thing. So I'm only breeding big bulls and big rams for hunting. That's all I do."

"Do they get hunted quite a bit?"

"It's starting now. The demand for them is...we have them with, our plan is to, you'll see a big blue wildebeest with them. You'll see a 32 and half inch spread. So we're breeding him with the golden females and then we'll get a split out of them again. Then we are going to source a 32 inch golden bull on the splits again to breed to see if we can breed big golden 
bulls for the hunting market there. So this is our long-term plan at the moment. We are also the owner of the biggest normal wildebeest in the country. He's the father of this bull. He's called Victor and he has a spread of 34 and 6/8ths. That one there is 32. To give you an idea a good trophy blue wildebeest will be 28 inches, it will be a very nice one. This one is 32 and a half and its father 34 . So that's quite a big...so had we not caught his father in the wild and started breeding him he would probably end up just being hunted and shot. And those genes would go; we'd never get it again. So that's why we want to preserve that."

Many hunters with whom I spoke remarked about the majestic quality of certain species, marveling at the spiral of their horns or their sheer body size. The quote above, however, goes beyond reverence for beauty, signaling a transformative subjectivity of beauty where the aesthetic is viewed through an economic lens. Individual nonhumans, once they achieve their biological potential are now perfect enough to die. The preservation of genes is motivated by turning profits from the nonhumans with the largest spreads. While ranching enthusiasts fetishize the genetic potential of their wildstock, a number of personal interviewees lamented the negative role that Rowland Ward and Safari Club International Record Books have had on the industry. This does not stop them from taking their money (personal communication, 2018 - "I'll take their money, mind you."), but "inch chasing" remains a blot on the industry that game ranchers are all too familiar.

"Some people come here and that's probably like $20 \%$ of the people, they come with expectation of (an) enormous trophy; they're inch hunters. They're looking for specific sizes and so on." - (personal communication, 2018)

Many international hunters, including Americans, are looking to contribute to conservation and community development, and learn about the local culture. Interviews revealed that Americans are respectful, courteous, and "good tippers". Americans, however, also happen to be the majority of the $20 \%$ that make up "inch-chasers" (personal communication, 2018). A number of high value species exist on the vast list of Safari Club International hunting awards, such as Continental Awards, Inner Circles, Cats of the World, and Grand Slams such as African Big 5 (leopard, lion, rhino, elephant, buffalo), African 29 (3 of Big 5 required, plus Nile crocodile, hippopotamus, and large number of high value antelope species including sable, gemsbok, and roan), and the Dangerous Game of Africa (maximum of 4 of the Big Five plus Nile crocodile and/or hippopotamus (www.scifirstforhunters.org, retrieved July 2019). Appeasing a clientele motivated by size may lead to further contradictions in conservation that intensify the production and killing of nonhumans.

\section{Put and Take}

Traditional "fair chase" hunters within the hunting community abhor what is called "put and take". This is the process of allowing a client to select the precise animal(s) he/she wants to shoot from photos taken for an auction. Once a client identifies the animal 
he/she wants the outfitter buys the animal(s) on the auction and puts it out onto a concession for the client to shoot. Quite simply, the outfitter "puts" the animal on a game farm, gives it very little time to adapt, and the domestic or foreign hunter shoots, or "takes" it. Put and take occurs at different scales, but generally occur on smaller farms that make more money from accommodation than game. One CEO from a major hunting association in SA offers an example of what "put and take" looks like.

I would have a small piece of land, I would go to an auction, I would buy 10 or 15 or 16 impala, would have them off loaded on my farm on Thursday. On Friday I have hunters come in and I hunt most of them. The next week I just buy some more and have them killed over the weekend. And the week thereafter do the same...kill maybe 40 animals over the weekend. It's basically a slaughter.

One game farmer put it this way:

Their gunshots are going off, they're shooting for the meat. So when they're paying 50\%...Brandy and coke is what we call it, a boys weekend out. Not all of them. A generalization. It's a party, rude and crude and they go out to just shoot something. I couldn't stand that.

We see that hunting safaris are not always trophy focused, as many farms also cater to local meat hunters. Additionally, the "boys weekend" may be motivated by business interests and network building that take place outside the farm.

One farmer said the following:

Most of our hunters are clients from construction. I'm going to be honest, you give them a hunting weekend at the end of the day they give you a new contract on the mines and stuff, so it plays a big part, not all of the time.

People can say what they want, I'm going to interact more with the clients and give them an experience, hunting and enjoying yourself...Boys weekend, it makes a big impression on your client.

Boys weekend does not include black businessmen. It is primarily white and exclusive. The described business relationship above underscores the importance of a shared cultural identity across the private sector, and points to the intensely masculine nature of hunting in South Africa and elsewhere. In this scenario, the wildlife ranchers manage a farm that was bought with mining profits. Preserving relations with prospective business partners is essential to maintaining the farm, particularly for farmers new to this livelihood production. The farm in question here could be considered merely a hobby of love for the young men managing and breeding wildlife (I observed, and one of the game managers was quick to admit some mistakes particularly regarding the rotation of land wildebeest were noticeably very thin) if not for the fact that it also functions as a vent for surplus capital. 
“...you know a lot of people have game farms but the money comes from another place, you know. They've got a business in Johannesburg or Pretoria or any other place and in a way it's a tax right off. They hook up a nice lodge, buy some animals."

A number of interviews revealed how successful businessmen buy land, wildlife, and vehicles to shelter them from taxes. The best way to avoid taxes is by hiding surplus in biocapital and additional assets (vehicles) necessary to the management of wildlife ranching. Companies such as De Beers Consolidated Mines Pty Ltd have an Ecology Division that focuses on genetic variability and diversity through selectively breeding high value species (buffalo, sable, roan, and tsessebe) on three farms that "are conservation focused since 1887 and support research elements in conservation" (http://www.debeerswildlife.co.za/about-us/, retrieved May 2019). The first part of this quote white washes South Africa's racist history. De Beers was focused on conservation, but not for nature's sake. It's primary consideration, not unlike the mining industry the world over, was enclosing land for extraction and private profit, which meant dispossession and displacement of indigenous and Bantu peoples. Creating an ecological division focused on "conservation" currently offsets and green washes the inherent environmental problems associated with mining. Winning a number of awards including the Nedbank Capital Green Mining Award (2010) and most recently the Zoological Society of South Africa Corporate Award (2013) highlights the public-private partnership underscoring South Africa's green economy. In this model De Beers appears to be a good corporate citizen despite causing environmental degradation elsewhere. According to their website, they acquired an additional 32,000 hectares of land in the 1990s that currently allow predators and other species to range freely on extensive areas. If private wealth can help procure wild habitat for threatened species, then the perception is winwin, effectively diverting attention from the privileged position of corporate elites that continue to acquire greater profits and land.

Corporate ties to the industry are manifold. Ranchers depend on capital from outside businesses. As mentioned previously, they give extra attention to corporate partners for the sake of their outside business ventures, which could involve the "put and take" of different species that were bought for the purposes of being hunted immediately. Additionally, wildlife ranchers offer local corporate packages meant to foment stronger business ties that are mutually beneficial. Specifically, corporate actors incentivize their employees with the reward of hunting and killing amongst co-workers. Hunting can lubricate socioeconomic relations, and also strengthen cultural identity. For example, trophy-hunting packages are also marketed to CEOs and managers that seek to brag and impress their associates and employees with stories of heroism and resilience in the bush (see figure $\mathrm{xxx}$ - "Bragging rights of the boss."). It's a performance of belonging that is meant to reinforce cultural identity, masculinity, and the appearance of power.

\section{Conclusion}

This paper demonstrates how wild nonhuman animal bodies are molded into new frontiers for capital accumulation. Under the guise of conservation, nonhumans are reduced to specific color or physical body parts, indicating a neoliberalized utilitarian 
approach that fosters a denaturalizing process where sentient beings live to die for human profit. From birth through death nonhumans are subject to intense human intervention, which involves the mediation of natural selection processes, genetic manipulation, cross breeding, darting, tagging, DNA testing, veterinary checkups, capture, forced displacement, intensive enclosures, put and take, trophy hunting, and culling. After death, nonhuman bodies remain part of the economic ecosystem, as they are skinned and draped over fireside chairs, eaten, beheaded, and following taxidermy, shipped off and hung as mantelpieces in living rooms across the industrialized world. In short, realizing a nonhuman animal's exchange value may occur at various stages in its highly manipulated life-death cycle.

The exploitative intensity of wildstock production is a natural expansion of neoliberalization and the discourses that nurture and normalize its associated market logics. In this mode the life of a nonhuman animal is susceptible to privatization, speculation and market fluctuation. Research participants noted how the market became oversaturated with high value species and color variants and how this resulted in the devaluation of species. They disclosed that decreased valuation meant a decline in animal care, as species such as impala were set loose from intensive enclosures.

"It (the market) got saturated. Too many people got in and started doing this. Yeah there's too many buyers now because everybody that had money have already bought the sable they want. Yeah it's getting tougher every year. And the price(s) is going down. And this year some guys stopped doing this because they didn't buy right in the beginning and don't have the right genes and they cannot afford to feed these animals and keep them in a smaller area anymore so they just broke the fences off and they're in a big reserve now. Just because financially it doesn't make sense to feed them anymore."

The degree to which nonhumans raised in encampments can properly fend for themselves remains questionable, meaning that their lives may end sooner than their wild counterparts. In other cases, impala that do not meet their genetic potential are culled and sold as meat on the local market (personal communication, Bona Bona game manager, 2018). As procuring sustainable and cheap protein sources are part of South Africa's green economy to increase food security, culling a herd of impala can be framed as performing a community service. ${ }^{3}$

In the hunting industry the meat gets sold back helping the economy and the people. Because it gets sold for a lower rate and everyone can eat it.

Indeed, the production of nature may be resolved across different spaces and time through the value chain, and green washed accordingly.

Industry actors tout genetic quality, bloodlines, and trophy and stud breeder potential across various mediums, including online websites, magazines, and social

\footnotetext{
3 Prolonged drought and loss of agricultural subsidization has made meat cost prohibitive for historically disadvantaged communities. The loss of agricultural subsidies, ironically, prompted cattle farmers to shift to farming the wild, now making both domestic and wild meat less accessible to rural communities. The wildlife ranching industry is currently trying to lobby for regulation that would accommodate scaling up wild game production for meat sales (personal communication with CEO Wildlife Ranching).
} 
media, and at conventions and auctions both domestic and abroad. Auctioneers draw on individual genealogy and previous sales to stimulate buyer interest, as well as body type and size, horn and boss measurement, color, age, and sex. Wildlife managers pay close attention to the development of an individual's ethology and physical attributes, as this will determine how they are separated from and integrated into social groups, and whether they become breeders that will be maintained in intensive enclosures or trophies that will be released onto extensive enclosures.

At the industry's core we find unfree nonhuman labor. Sable, buffalo, roan, tsessebe, and wildebeest are only a few of the species that must provide their own reproductive labor. Historically, while unfree nonhuman labor (i.e. cattle) preceded the transition to wildlife production, labor is now increasingly imposed upon a larger diversity of nonhuman species. This development occurred over time in the context of global discourses of environmental disrepair, as well as political and economic crises in South Africa. Due to loss of agricultural subsidies, as well as new labor laws guaranteeing increased wages, agricultural farmers shifted to wildlife ranching production as a way to reduce the number of laborers needed on their farms.

Capital seeks a relative surplus of reserve laborers/inputs/commodities, such as entities with future exchange value like genetic resources and game that are available for harvest (Collard and Dempsey, 2013). As economic crises may force capital to restructure its labor process (Brass, 1994), exploitation of both human and nonhuman animals may occur (Simon, 2016). Wildlife ranchers' ability to adapt to capitalist crises has its roots in colonial processes of dispossession: transforming the landscape may not be as difficult when one already owns it (depending on debt accrued) and has invested money and resources into its infrastructure. By drawing on the built in environment the most successful wildlife ranchers were able to fix and maintain their livelihoods (Ekers and Prudham, 2015). Harvey argues that the spatio-temporal fix has a double meaning fixed capital in landscape (institutions, infrastructure), and how long-term investments in geographical expansions provide a solution (a 'fix') for crises of overaccumulation of capital (Harvey, 2001). In this context, the "fix" also applies to investors and businessmen, both domestic and abroad, who use wildlife and land as vents for surplus capital. According to a number of research participants, business owners use "game" as a way to write off taxes. It goes without saying that providing tax shelters for the wealthy and well connected contradicts wildlife industry discourses of social transformation. My findings indeed coincide with Kamuti (2015), who proffers that private game farming remains a class issue.

One wildlife rancher/professional hunter/taxidermist made a comment that reflects the class issues inherent to commodifying nature:

We got very very (repetition in original statement) high up clients in America. The president of JP Morgan and Chase Banks is one of our clients. He's got very wealthy clients that bank with them. We go over to America and do house parties and go to the Dallas (Safari Club) show. You know we meet the people and they come and do the hunts. Americans pay a premium on bigger animals, especially buffalo and sable. 
Inch chasers, business owners with more lucrative trades, investors, and wealthy emirs are drawn to the wildlife industry, suggesting its deep ties to privilege, power, and capital.

This paper broadens our understanding of the political economy of nature, as it exposes, describes, and evaluates the internal processes and contradictions of marketbased nature production. The logics underpinning the neoliberalization of nature nurture new illogics whereby nonhumans are reduced to biocapital. South Africans can own wildlife so long as they are adequately fenced, tantalizing farmers to move beyond merely putting wild animals on their land to have them hunted for profit. Hunting wildlife, particularly on fenced land, requires a sustainable and healthy stock. To ensure a perpetual bounty to "harvest", landowners, safari outfitters, and trophy hunters have come to rely upon wildlife ranches that breed specific nonhumans with specific traits. The result has been a niche market meant to satisfy an international clientele motivated by "inches" and color variation. Producing nature of exceptional horn length, body size, and color, what I refer to as super species, resulted in a great accumulation of wealth for mostly white private landowners and businessmen. In essence, it turned an already cost prohibitive activity into one even more exclusive for game farmers/wildlife ranchers seeking to compete in a growing market, for local communities to access land, and for hunters seeking to add to their taxidermic collection.

As trophy hunting depends upon wildlife ranching to supply a sustainable harvest with an appropriate encounter value (Barua, 2016) and for a practice that is debatably wanton and masculine, it raises serious concerns regarding what is morally acceptable entertainment. While I recognize that the wildlife ranching industry has contributed in ways that have fostered positive conservation outcomes, market-based conservation eschews nonhuman sentience, liveliness, social relations, and their contributions to ecosystems -- for profit. So long as conservation continues to be guided by a utilitarian neoliberal approach, nonhumans will be viewed as objects for trade and subject to new and various forms of violence and exploitation.

\section{Works Cited}

Aitken, S., \& Valentine, G. (2006). Ways of knowing and ways of doing geographic research. Approaches to human geography, 1-12.

Ahmadvand, M. (2011). Critical Discourse Analysis An introduction to major approaches. Jurnal Ilmiah Dinamika Bahasa dan Budaya, 5(1), 82-90.

Andrew, N., Brandt, F., Spierenburg, M., Snijders, D., \& Mkhize, N. (2013). Land consolidation and the expansion of game farming in South Africa: impacts on farm dwellers' livelihoods and rights to land in the Eastern Cape. In Africa for Sale? (pp. 95-130). Brill.

Barua, M. (2017). Nonhuman labour, encounter value, spectacular accumulation: The geographies of a lively commodity. Transactions of the Institute of British Geographers, 42(2), 274-288. 
Barua, M. (2016). Lively commodities and encounter value. Environment and Planning D: Society and Space, 34(4), 725-744.

Batavia, C., Nelson, M. P., Darimont, C. T., Paquet, P. C., Ripple, W. J., \& Wallach, A. D. (2019). The elephant (head) in the room: A critical look at trophy hunting. Conservation Letters, 12(1), e12565.

Biermann, C., \& Anderson, R. M. (2017). Conservation, biopolitics, and the governance of life and death. Geography Compass, 11(10), e12329.

Bluwstein, J., \& Lund, J. F. (2018). Territoriality by conservation in the Selous-Niassa Corridor in Tanzania. World Development, 101, 453-465.

Brand, U. (2012). Green economy-the next oxymoron? No lessons learned from failures of implementing sustainable development. GAIA-Ecological Perspectives for Science and Society, 21(1), 28-32.

Brandt, F., \& Spierenburg, M. (2014). Game fences in the Karoo: reconfiguring spatial and social relations. Journal of Contemporary African Studies, 32(2), 220-237.

Brandt, F., Josefsson, J., \& Spierenburg, M. J. (2018). Power and politics in stakeholder engagement: farm dweller (in) visibility and conversions to game farming in South Africa.

Brass, T. (1994). Some Observations on Unfree Labour, Capitalist Restructuring, and Deproletarianization 1. International review of social history, 39(2), 255-275.

Brockington, D. (2002). Fortress conservation: the preservation of the Mkomazi Game Reserve, Tanzania. Indiana University Press.

Brockington, D., \& Duffy, R. (Eds.). (2011). Capitalism and conservation (Vol. 45). John Wiley \& Sons.

Büscher, B. (2013). Transforming the frontier: peace parks and the politics of neoliberal conservation in Southern Africa. Duke University Press.

Büscher, B., \& Ramutsindela, M. (2016). Green violence: Rhino poaching and the war to ave Southern Africa's peace parks. African Affairs, 115(458), 1-22.

Büscher, B., Sullivan, S., Neves, K., Igoe, J., \& Brockington, D. (2012). Towards a synthesized critique of neoliberal biodiversity conservation. Capitalism nature socialism, 23(2), 4-30.

Carruthers, J. (2008). Conservation and wildlife management in South African national parks 1930s-1960s. Journal of the History of Biology, 41(2), 203-236. 
Castree, N. (2003). Commodifying what nature?. Progress in human geography, 27(3), 273-297.

Castree, N. (2005). Nature. Routledge.

Castree, N. (2008). Neoliberalising nature: processes, effects, and evaluations. Environment and planning A, 40(1), 153-173.

Chrulew, M. (2011). Managing love and death at the zoo: The biopolitics of endangered species preservation. Australian Humanities Review, 50(1).

Clifford, N., Cope, M., Gillespie, T., \& French, S. (Eds.). (2016). Key methods in geography. Sage.

Coetzee, J. M. (2016). The lives of animals (Vol. 43). Princeton University Press.

Collard, R. C., \& Dempsey, J. (2013). Life for sale? The politics of lively commodities. Environment and Planning A, 45(11), 2682-2699.

Collard, R. C. (2014). Putting animals back together, taking commodities apart. Annals of the Association of American Geographers, 104(1), 151-165.

Corson, C. (2011). Territorialization, enclosure and neoliberalism: non-state influence in struggles over Madagascar's forests. Journal of Peasant Studies, 38(4), 703-726.

Cousins, J., Sadler, J., \& Evans, J. (2008). Exploring the role of private wildlife ranching as a conservation tool in South Africa: stakeholder perspectives. Ecology and society, 13(2).

Cousins, J. A., Evans, J., \& Sadler, J. (2009). Selling conservation? Scientific legitimacy and the commodification of conservation tourism. Ecology and society, 14(1).

Cousins, J. A., Sadler, J. P., \& Evans, J. (2010). The challenge of regulating private wildlife ranches for conservation in South Africa. Ecology and Society, 15(2).

Creswell, J. W., \& Tashakkori, A. (2007). Differing perspectives on mixed methods research.

Cundill, G. (2010). Monitoring social learning processes in adaptive co-management: three case studies from South Africa. Ecology and Society, 15(3).

Dickson, B., Hutton, J., \& Adams, W. A. (Eds.). (2009). Recreational hunting, conservation and rural livelihoods: science and practice. John Wiley \& Sons.

Dowie, M. (2009). Conservation Refugees. The Hundred-Year Conflict between Global Conservation and Native Peoples. MIT Press. 
Duffy, R. (2014). Waging a war to save biodiversity: the rise of militarized conservation. International Affairs, 90(4), 819-834.

Ekers, M., \& Prudham, S. (2015). Towards the socio-ecological fix. Environment and Planning A, 47(12), 2438-2445.

Emel, J., Wilbert, C., \& Wolch, J. (2002). Animal geographies. Society and Animals, 10(4), 407-412.

Escobar, A. (1995). Encountering Development: The Making and Unmaking of the third world. Princeton Studies in Culture/Power/History. Princeton University Press. Princeton. New Jersey.

Fairhead, J., Leach, M., \& Scoones, I. (2012). Green grabbing: a new appropriation of nature?. Journal of Peasant Studies, 39(2), 237-261.

Furstenburg, D. (2016). Endangered bontebok and small game survival: a quest of palaeontology, climate change, consumptive use and biodiversity management in SA. In 9th International Wildlife Ranching Symposium. Colorado State University. Libraries.

Gamborg, C., \& Gjerris, M. (2012). For the benefit of the land? Ethical aspects of the impact of meat production on nature, the environment and the countryside. In Climate change and sustainable development (pp. 202-206). Wageningen Academic Publishers, Wageningen.

Gewald, J. B., Spierenburg, M., \& Wels, H. (2018). Nature conservation in southern Africa: Morality and marginality: Towards sentient conservation? Brill.

Gewald, J. B., Spierenburg, M., \& Wels, H. (2018). Introduction: People, Animals, Morality, and Marginality: Reconfiguring Wildlife Conservation in Southern Africa. In Nature Conservation in Southern Africa (pp. 1-22). Brill.

Gregory, D. (2004). The Colonial Present: Afghanistan, Palestine, Iraq (pp. 1-15). Blackwell Pub.

Haraway, D (2013). When species meet. (Vol. 3). U of Minnesota Press.

Harvey, D. (1998). What's Green and Makes the Environment Go Round? In F. Jameson and M. Miyoshi, eds., The Cultures of Globalization. Durham: Duke University Press, pp. 327-355.

Harvey, D. (2001). Globalization and the "spatial fix". Geographische Revue, 2, 23-30. 
Harvey, D. (2003). The new imperialism: accumulation by dispossession. Socialist register, 63-87.

Harvey, D. (2005). From globalization to the new imperialism. Critical globalization studies, 91-100.

Harvey, D. (2007). A brief history of neoliberalism. Oxford University Press, USA.

Harvey, D. (2014). Seventeen contradictions and the end of capitalism. Oxford University Press.

Hayden, C. (2003). When nature goes public: The making and unmaking of bioprospecting in Mexico. Princeton University Press.

Herod, A. (1997). From a Geography of Labor to a Labor Geography: Labor's Spatial Fix and the Geography of Capitalism. Antipode, 29(1), 1-31.

Heynen, N., \& Robbins, P. (2005). The neoliberalization of nature: Governance, privatization, enclosure and valuation. Capitalism Nature Socialism, 16(1), 5-8.

Heynen, N., McCarthy, J., Prudham, S., \& Robbins, P. (2007). Introduction: false promises. In Neoliberal Environments (pp. 13-34). Routledge.

Hribal, J. (2003). "Animals are part of the working class": a challenge to labor history. Labor history, 44(4), 435-453.

Huber, M. T. (2017). Hidden abodes: Industrializing political ecology. Annals of the American Association of Geographers, 107(1), 151-166.

Hughes, D. M. (2005). Third nature: making space and time in the Great Limpopo Conservation Area. Cultural Anthropology, 20(2), 157-184.

Hutton, J. M., \& Leader-Williams, N. (2003). Sustainable use and incentive-driven conservation: realigning human and conservation interests. Oryx, 37(2), 215-226.

Igoe, J., \& Brockington, D. (2007). Neoliberal conservation: a brief introduction. Conservation and society, 5(4), 432-449.

Johnson, T. P. (2014). Snowball sampling: introduction. Wiley StatsRef: Statistics Reference Online.

Kamuti, T. (2015). A critique of the Green Economy-approach in the wildlife ranching sector in South Africa. Africa Insight, 45(1), 146-168. 
Kamuti, T. (2014). The fractured state in the governance of private game farming: the case of KwaZulu-Natal Province, South Africa. Journal of Contemporary African Studies, 32(2), 190-206.

Kepe, Thembela, Rachel Wynberg, and William Ellis. "Land reform and biodiversity conservation in South Africa: complementary or in conflict?." The International Journal of Biodiversity Science and Management 1, no. 1 (2005): 3-16.

Kepe, T. (2008). Land claims and co-management of protected areas in South Africa: exploring the challenges. Environmental management, 41(3), 311-321.

Kimmerer, R. W. (2013). Braiding sweetgrass: Indigenous wisdom, scientific knowledge and the teachings of plants. Milkweed Editions.

Laurier, E. (2010). Participant observation. Key methods in geography, 133.

Leach, M. \& Mearns, R., (1996). The Lie of the Land: Challenging Received Wisdom on the African Environment. Indiana University Press.

Li, T. M. (2011). Centering labor in the land grab debate. The Journal of Peasant Studies, 38(2), 281-298.

Lindsey, P. A., Alexander, R., Frank, L. G., Mathieson, A., \& Romanach, S. S. (2006). Potential of trophy hunting to create incentives for wildlife conservation in Africa where alternative wildlife-based land uses may not be viable. Animal Conservation, 9(3), 283-291.

Lindsey, P. A., Frank, L. G., Alexander, R., Mathieson, A., \& Romanach, S. S. (2007). Trophy hunting and conservation in Africa: problems and one potential solution. Conservation biology, 880-883.

Lindsey, P. A., Roulet, P. A., \& Romanach, S. S. (2007). Economic and conservation significance of the trophy hunting industry in sub-Saharan Africa. Biological conservation, 134(4), 455-469.

Longhurst, R. (2003). Semi-structured interviews and focus groups. Key methods in geography, 3, 143-156.

Lorimer, J. (2015). Wildlife in the Anthropocene: conservation after nature. $\mathrm{U}$ of Minnesota Press.

Marx, K. (2011). Capital, Volume I: A critique of political economy (Vol. 1). Courier Corporation.

MacDonald, K. I. (2010). The devil is in the (bio) diversity: Private sector "engagement" and the restructuring of biodiversity conservation. Antipode, 42(3), 513-550. 
Marshall, C. R., \& Rossman, B. G.(2006). Designing qualitative research, 161.

McAfee, K. E. (1999). Biodiversity and the contradictions of green developmentalism. University of California, Berkeley.

McCusker, B., Moseley, W. G., \& Ramutsindela, M. (2015). Land reform in South Africa: An uneven transformation. Rowman \& Littlefield.

McDermott, D. (2005). Third Nature: Making Space and Time in the Great Limpopo Conservation Area. Cultural Anthropology, Vol. 20, No. 2.

Mkhize, N. (2014). Game farm conversions and the land question: unpacking present contradictions and historical continuities in farm dwellers' tenure insecurity in Cradock. Journal of Contemporary African Studies, 32(2), 207-219.

Morse, P. N. S., \& Corbin, B. (2009). Developing grounded theory. The second generation.

Mullin, M. H. (1999). Mirrors and windows: sociocultural studies of human-animal relationships. Annual review of anthropology, 28(1), 201-224.

Neumann, R. P. (2015). Political ecology of scale. In The international handbook of political ecology. Edward Elgar Publishing.

Ramutsindela, M., \& Shabangu, M. (2013). Conditioned by neoliberalism: a reassessment of land claim resolutions in the Kruger National Park. Journal of Contemporary African Studies, 31(3), 441-456.

Rose, J. (1997). Soft systems methodology as a social science research tool. Systems Research and Behavioral Science: The Official Journal of the International Federation for Systems Research, 14(4), 249-258.

Ribot, J. C., \& Peluso, N. L. (2003). A theory of access. Rural sociology, 68(2), 153-181.

Robbins 1, P., \& Luginbuhl, A. (2005). The last enclosure: resisting privatization of wildlife in the western United States. Capitalism Nature Socialism, 16(1), 45-61.

Robbins, P. (2011). Political ecology: A critical introduction (Vol. 16). John Wiley \& Sons.

Saayman, M., van der Merwe, P., \& Saayman, A. (2018). The economic impact of trophy hunting in the South African wildlife industry. Global Ecology and Conservation, 16, e00510.

Sharp, J. (2008). Geographies of postcolonialism. Sage. 
Simon, A. (2016). Against trophy hunting: a Marxian-Leopoldian critique. Monthly Review, 68(4), 17.

Smith, N. (2008). Uneven development: Nature, capital, and the production of space. University of Georgia Press.

Snijders, D. (2012). Wild property and its boundaries-on wildlife policy and rural consequences in South Africa. Journal of Peasant Studies, 39(2), 503-520.

Snijders, D. (2015). Shifting species in South Africa: wildlife policy, rural consequences. Dissertation. VU University, Amsterdam, The Netherlands. [online] URL: https://research.vu.nl/en/ publications/shifting-species-in-south-africa-wildlife-policy-ruralconsequenc

Spierenburg, M., \& Brooks, S. (2014). Private game farming and its social consequences in post-apartheid South Africa: contestations over wildlife, property and agrarian futures. Journal of Contemporary African Studies, 32(2), 151-172.

Spierenburg, M. (2018). The emergence and socio-economic impacts of wildlife ranching in South Africa. In Nature Conservation in Southern Africa (pp. 167-188). BRILL.

Stevens, S. F., \& Dean, T. D. (1997). Conservation through cultural survival: Indigenous peoples and protected areas. Island Press.

Taylor, A. N. D. R. E. W., Lindsey, P. A., Davies-Mostert, H. A. R. R. I. E. T., \& Goodman, P. E. T. E. R. (2016). An assessment of the economic, social and conservation value of the wildlife ranching industry and its potential to support the green economy in South Africa. The Endangered Wildlife Trust, Johannesburg, 96-109.

TREES. 2017. A marketing and spending analysis of trophy hunters 2015/2016 season, Tourism Research in Economic Environs and Society, North-West University, Potchefstroom, South Africa.

Waugh, L. R., Catalano, T., Al Masaeed, K., Do, T. H., \& Renigar, P. G. (2016). Critical discourse analysis: Definition, approaches, relation to pragmatics, critique, and trends. In Interdisciplinary studies in pragmatics, culture and society (pp. 71 135). Springer, Cham. 


\section{Chapter 3}

\section{An historical approach to understanding the attitudes and practices driving South Africa's wildlife industry}

\section{Abstract}

This paper focuses on the discourses, legislation, practices, and partnerships that both buttress and threaten South Africa as the number one trophy-hunting destination on the African continent. Taking an historical approach, I argue that the spatialization of private conservation and the killing of nonhuman animals are accommodated by a combination of identity politics discourses, epistemologies, and an international market-based approach that both signify and threaten a colonial present. Using an ethnographic approach, this paper reveals and assesses the contradictions and tensions found within each of the aforementioned components. Wildlife industry advocates owe their conservation success to privatization and placing a value on wildlife. It is precisely the privatization of land and wildlife that insulates South African wildlife ranchers, steadfast in their determination to protect their land and livelihood, which makes their involvement in the development of the green economy so crucial. As economic transformation is slow in its development, the socioeconomic benefits associated with land ownership are politicized. White South African game farmers perceive threats of physical violence against them as calls for land expropriation without compensation generate increased paranoia and securitization. As tension builds, an ethical disagreement amongst South African hunting associations threatens to destabilize South Africa's brand as a place for fair chase hunts and international investment. The phenomenon of canned hunting puts South Africa at risk of losing business to its northern neighbors in Namibia, who can compete with South Africa's diversity of species and draw on their track record of conservancies to attract more socially conscientious hunters from abroad. A number of white South African game farmers argue that they're African, and belong to the land, arguing that the West and its assemblage of conservation and wildlife trading organizations impose its values on them without consideration or knowledge of the reality on the ground.

"Neoliberalism, through tourism, reconfigures and redesigns nature for global consumption" (Duffy and Moore, 2010: 762; West and Carrier 2004).

In 1964, we had about 575,000 wild game animals countrywide. During the 1960s, safari hunting and game ranching were mere fledglings in South Africa, but the fact of the matter is that hunting started to place a value on wildlife and wild areas, creating a direct incentive to purchase, own, protect and conserve this precious resource. It became a viable investment. As the safari hunting industry began to grow and with it, the demand for South Africa as a destination, more and more land was converted from agriculture to wildlife. Today we can boast a wildlife population close to 24 million head of game. -Professional Hunter's Association of South Africa (PHASA), Information

Booklet, 2016 


\section{Introduction}

"Modern sport hunting is unbound from subsistence needs and responds to potentially insatiable yearnings - there is always hope for a bigger trophy or a better hunt" (Hirschman, 2003; McGuigan, 2017).

Tourism in South Africa began to take on a larger economic role at the time of its democratic transition, and coincided with popular development and environmental discourses championing neoliberal economic policies placing monetary value on ecosystem services and wildlife derivatives. As signatory to the Convention on Biological Diversity (1992), South Africa recalibrated its economic trajectory in environmental terms, eschewing subsidization of agricultural production in favor of conservation that would attract foreign capital and presumably alleviate rural poverty. Post-apartheid South Africa, no longer international pariah, but rather the Rainbow Nation, opened its borders and arms to tourists from around the world and quickly branded itself a world-class destination, a "world in one country" (Carruthers, 2007) offering the traveler everything from hot air balloon rides, wineries, traditional cultures and cuisines to mountains, coastlines, deserts, and bush safaris.

The identity of South Africa remains one inexorably linked with wildlife (Beinart, 2000); it is the primary drawing card that attracts tourists from all over the world to visit. Many who choose to visit South Africa come for safari, to experience and observe the wildlife of their African dreams roam free in their 'natural' habitat. Disney films and magazines like National Geographic have provided their share of iconic African imagery depicting a wild, Edenic nature generally anthropomorphized, pristine, exotic, and free of humans (Sharp, 2008; Igoe, 2004). Video and imagery may include a lion's penetrating glare off into the distance, a crocodile snapping its teeth at an unwitting wildebeest, a troop of baboons descending from a baobab tree, or an orange pulpy sunset silhouetting a procession of elephants traipsing slowly across an acacia-laden horizon. These images trigger a host of emotional responses, some which lead civil society to write checks to non-governmental organizations claiming to save nature from human development, poaching, and extractive industries, or even inspire foreigners to climb aboard a plane and visit these beautiful, 'wild' places when money and time permit.

The wildlife habitat in South Africa, however, is anything but 'natural', ("Everything is fenced!" as one game farmer put it) as one drive through Kruger National Park (KNP) quickly reveals a tangle of tarmac roads, safari vehicles, commercial fast food restaurants, and cost-prohibitive chalets that continue to reflect a racial and class divide. More accurately, KNP reflects a human landscape, a nature marketed and manipulated to conform to human consumption. Many visitors consumed with seeing the Big Five (leopard, lion, elephant, rhino, African buffalo) hurriedly speed past less charismatic species unobservantly to then compete with a bevy of safari trucks parked imposingly close to wildlife. Car engines run incessantly, while the vehicle interior is replete with loud whispers, laughter, and the shutter of expensive cameras. Watching drivers sandwich their vehicles onto the sides of roads in a struggle to gain a better vantage point appears more a traffic jam than connecting with nature or an escape from urban civilization. As South Africa fences its wildlife, public parks such as KNP risk becoming more like zoos or amusement parks than the African safari of one's dreams. 
Not all nature enthusiasts go to South Africa to shoot the wildlife of their dreams with a camera. There are approximately 7,000 tourists (Dickson et al., 2009), however, who are more interested in shooting wildlife with a rifle or a bow. While some trophy hunters may be drawn to the exoticism of 'wild Africa', they tend to avoid the large crowds that gravitate to KNP. Trophy hunters, rather, are drawn to the diversity of species available in South Africa (TREES, 2017), as well as a large number of private game farms situated only a two hour drive from Oliver Tambo International airport in Johannesburg via a network of tarmac roads. South Africa's infrastructure and convenience plays a central role in the development of trophy hunting on wildlife ranches. It's built-in and improving infrastructure, indeed, makes it easier for international trophy hunters with limited time to fit in a hunting safari of their choice. Under time constraints, trophy hunters want to maximize the diversity of places and species they can hunt, and therefore see South Africa as a win-win hunting destination. South Africa also has many well-renown and easy-to-access tourist destinations that can be visited by the family during or after their father's/husband's/parent's safari, which factors into decisions regarding one's hunting destination. According to a Wildlife Ranching South Africa (WRSA) presentation at Safari Club International's Annual Hunter's Convention (2108), South Africa is affordable, convenient, safe, and provides good service and good value for your money.

"The main reason they select $S A$ is it's very easy to get in and out of country. Not main reason, but you will get for instance I think the main thing for hunting the number of species available; the diversity is the main reason. If they don't come here they go to Zambia for sable, all those trips took time. Whereas safaris were 24 days, now they are 7-10 days because life is so rushed, can't spend so much time away from work. Now South Africa has all those species available, a very big draw card. It's a safe country, can go to Cape Town, Kruger, it's a world in one country." (personal conversation with wildlife rancher, 2018)

The Department of Environmental Affairs (DEA) and provincial tourism authorities recognize how money gets distributed before (airfare, licensing fees, etc.), during (food, accommodation, etc.), and after (taxidermy, post-safari travel, etc.) hunting safaris and contributes to the wider South African economy. Trophy hunting supports more than 17, 000 employment opportunities in South Africa, benefiting mostly the agricultural and manufacturing sectors (Saayman et al., 2018). Proponents of trophy hunting draw on its economic impacts to legitimize its relevance to conservation, and owe its overall success to the private model.

South Africa has increasingly come to depend on a rural "mosaic of private reserves" (Beinart and Coates, 1995) numbering over 9,000 (Taylor et al., 2016) to protect the nation's biodiversity. Wildlife ranching, including trophy hunting, biltong hunting, and the breeding of wildlife, occurs on privately owned land, which is where an estimated $80 \%$ of nature conservation in South Africa takes place (Van der Merwe et al. 2014). While trophy hunting occurs in 23 sub-Saharan African countries, South Africa has the most operators, most visiting foreign hunters (majority from the United States), largest number of animals shot, and highest revenue generated from hunting permits and lodging fees (Lindsey et al., 2007). Trophy hunters contribute approximately ZAR5 
billion annually to South Africa's economy (Saymaan et al., 2018), which represents only two percent of South African tourism (Taylor et al., 2016). By comparison, biltong hunting contributes $\sim 90 \%$ of the total income generated by the hunting industry (Van Der Merwe et al., 2014). If trophy hunting generates only a very small percentage of international tourism and the overall hunting industry, then we should reevaluate its significance and the processes, partnerships, and discourses that buttress its international relevance. In the sections below, I place trophy hunting in historical context to argue that the spatialization of private conservation and the killing of nonhumans remain both contingent upon and threatened by market-based approaches to conservation, colonial epistemologies, and political discourses of racial and cultural identity.

This paper weaves together South Africa's history of conservation and colonialism with its current political and cultural landscape, thus highlighting the myriad ways a predominantly white trophy hunting industry uses race, identity, scale, and the green economy to deflect public scrutiny and preserve the private accumulation of land and capital. Maintaining the private mode of conservation comes with ethical dilemmas, which are reviewed accordingly and with respect to maintaining the industry's public image. Finally, this paper advances our understanding of the relationship between conservation and colonialism, as it illustrates how different manifestations of colonialism (settler colonialism, colonialism, and post-) operate simultaneously in space and time and continue to shape practice, policy, and perception through similar discourses, attitudes, and processes.

\section{Historical Background}

"South Africa emerged as a state before it became a nation, and so the construction of nation required the cultivation of cultural identity and solidarity, a cultural core answered by bounded geographical space, involving complex processes of manipulation and control of the environment, the molding and interpretation of space, the definition and hardening of national boundaries and the imaginative abstraction, inhabitation, and use of the nation's territory through cultural discourse" (Foster 2008: 16).

Settler colonies transformed the physical and cultural landscape and are central to describing how the relationship between conservation and trophy hunting evolved over the past three and half centuries (Beinart, 2000). Like other settler colonies, such as the United States, the story of South African conservation can be interpreted through the following social, environmental, political, and economic lens: Social Darwinism and its accompanying racist assumptions (Said, 1978), masculine categorizations and binaries; scientific inquiry and collection (Foster, 2008); the rise of popular environmentalism (Robins, 2004; 2012); myths of environmental degradation (Leach and Mearns, 1996); indigenous dispossession (Sharp, 2008); hunting controls to preserve imperial domain (MacKenzie, 1997); a transition between agricultural and industrial production; urbanization; and its most recent iteration - neoliberalism and the commodification of nature (Castree, 2004; Peluso and Lund, 2011; Buscher et al., 2012). The result of the conservation ethic is inarguably a fragmented, hyper-controlled, artificial boundary-laden landscape, reflecting how conventional Western perspectives on spatial organization are 
powerfully shaped by concepts of property, in which pieces of territory are viewed as "commodities" capable of being bought, sold, or exchanged at the market place (Soja, 1971).

Colonial notions of conservation are based on epistemological assumptions of an external nature (Smith, 1984). Colonial epistemologies and binaries informed the South African national park system and the proliferation of nature reserves, game reserves, and private wildlife ranches present today. Prior to European conquest, "relations existed among the individual, society, and the physical world" (Berghoefer et al, 2010:16). In the African version of wildlife conservation history, the experience has been that game reserves are European inventions that "elevate wildlife above humanity" and have "served as instruments of dispossession and subjugation" (Carruthers, 1995: 101). Conservation in Africa was an increasingly exclusive pursuit where the only legitimate human roles were those of ranger, scientist and camera-clicking tourist (Beinert \& Coates, 1995). In essence, conservation initiatives devalued African livelihoods in favor of ecological values and international monetary exchange, which informed the conservation and control system of closed-access regimes, or more popularly fortress conservation (Stevens and Dean, 1997; Brockington, 2002). In other words, wildlife conservation and tourism in the colonial and apartheid eras was "non developmental" (Giampiccoli et al., 2014; Frey and George, 2010; Faasen and Watts, 2007: 36). Colonial land policy restricted access to land or appropriated land through the creation of reserves as a way of deliberately limiting the livelihood and income that people could gain from the land and forcing them to seek wage labor or migrate in search of wage labor to meet their basic needs (Moyo, 2008). While black South African labor was crucial to the mining and agricultural sectors, black South Africans were viewed as impediments to capital accumulation by conservation (Kepe, 2005 et al.; Hutton et al., 2005). These conditions provided excellent safari opportunities for adventurers and later tourists expecting a "pristine" and "wild" African landscape devoid of poor Africans (Neumann, 1998).

The primary impulse for conservation and game reserves derived from late nineteenth-century concerns about predatory hunting and the disappearance of game species (hunting laws were ineffectually enforced) (Beinert \& Coates, 1995). White trophy hunters in the spirit of Theodore Roosevelt were given great freedom to hunt indiscriminately. Trophy hunting was a sport celebrated by white settlers, international elitists, and explorers who decimated the wildlife for the sake of collecting scientific specimens, writing and selling masculine stories of bravado, and profiting via the ivory trade (Beinart, 2013). Catering to a masculine clientele still exists, along with tropes of an uncivilized Africa subject to making the white man's dreams come true.

"The thrill of hunting dangerous and plains game is what has drawn the HARD CORE HUNTER to Africa for over a century. Follow their footsteps to the "Dark Continent" where HFS will help you make your dreams a reality..." (emphasis in original) (http://www.huntleysafari.co.za, retrieved July 2018)

The hunting of wildlife, however, was not limited to sport or commercial exploits; it was also directly related to agricultural policies (Ramutsindela, 2012). Many species, such as jackal, caracal, and wild dog, were killed to protect livestock and were considered vermin 
(Beinart, 2000). ${ }^{4}$ Game reserves served to curb the overexploitation of specific wildlife species, but were met with great resistance from competing hegemonies representing various economic sectors, including mining companies, land speculators, and agricultural veterinarians and entomologists concerned with the spread of the tsetse fly (Beinart, 2000). The influence of the latter was due to their work promoting and developing commercial livestock and crop-farming industries (Carruthers, 2008). Conflict between wildlife and agriculture occurred in many instances, most notably in the Eastern Cape in the Addo area where a herd of 150 elephants were nearly all exterminated on account that they had raided and destroyed a citrus irrigation system (Carruthers, 2008). The idea of conservation would not gain traction until after the second Boer War, which saw the continued destructive consequences of over-hunting.

James Stevenson-Hamilton, first warden of Sabi reserve, pushed for legislation which would ensure that wildlife would be protected in its entirety and not solely as isolated game species (Beinert \& Coates, 1995), all of which was represented in the Report of the Game Reserves Commission in 1918. The authors of the report, under the guidance of European elitist notions grounded in science, imagined reserves to be used as training grounds for zoologists and botanists, and where animal behavior could be studied in an area less affected by hunting, which in other parts of the country tends completely to alter their habits (Carruthers, 1989). At this time, colonial collections of various specimens reflected a preoccupation with classifying animals that was exhibited in gardens and museums in Pretoria and Cape Town. Kirstenbosch Botanical Gardens exemplified this scientific turn, but more importantly "confirmed imperial ties and helped constitute an emergent national identity” (MacKenzie, 1997; Foster, 2008: 61).

Frontiers of hunting, livestock management, and resource extraction were all very powerful symbols for new nations and masculinities (Beinart and Coates, 2002). The materialization of Kruger National Park (1926) came to fruition on account of environmentalists playing to a burgeoning sense of Afrikaner pride. According to Carruthers (1989), the creation of Kruger depended less on public support for conservation than on the surge of white nationalism. The Kruger name was invoked by English-speaking propagandists of the national parks to lend the campaign legitimacy in the eyes of Afrikaners who had recently won a national election (1924) (Beinert \& Coates, 1995). Paul Kruger was former President of the Transvaal and a leader of resistance against the British. From the national park's name evolved a new national pride in its game animals, which became a recurrent motif in white South Africa's conception and projection of itself (Beinert \& Coates, 1995). If you look at South African money today, you will notice the face of Nelson Mandela on one side of each bill, but also one of the Big Five (lion, elephant, leopard, rhino, and African buffalo) on the other. The name of their national rugby team is the Springboks. The name of their cricket team, though not an animal, symbolizes a pride in their national environment: the Proteas.

Although this newfound identity may have helped to bolster the state's revenue (South African national parks were public land and were not open to privatization), it had devastating consequences for indigenous populations who clashed with state police forces. Definitions over 'poaching' differed, as many Africans claimed a right to hunt

\footnotetext{
${ }^{4}$ Today landowners may allow hunters to shoot these species at very low cost or be thrown in for free, as they are now hunted within enclosed game farms to protect higher value species such as kudu, roan, copper, black or white impala, sable, etc., that generate greater revenue.
} 
animals they had historically hunted for subsistence. Hand-to-hand battles and gunfights occurred in Natal between rangers and "poachers", as many Africans would not recognize the new spatial boundaries (Beinert and Coates, 1995). Black South Africans were forcefully removed to make new parks and reserves, barred from them, did not benefit from them, and were cut off from all the resources located within these areas. These historical truths, to this day, haunt and continue to capture the imagination of local communities as they negotiate wildlife game farms with landowners and other protected areas with national and provincial conservation agencies.

New spatial boundaries carved out by conservation policies were predicated upon the belief that black South Africans were incapable of understanding the value of land and thus could not steward the land appropriately. Racist imaginings of the Other (Said, 1978), applied in the conservation context, led to ahistoric and apolitical simplifications of land degradation. It is impossible to conceive of colonialism or imperialism 'without important philosophical and imaginative processes at work in the production as well as the acquisition, subordination and settlement of space' (Gregory, 1994: quoting Said, 1989: 218). Viewed through a post-colonial lens, "there is indeed no singular time and space of colonialism/postcolonialism - but only the transient moment of many intersecting temporalities and spatialities drawn into relation” (Braun, 1997). Each landscape is therefore not ahistorical but rather a conglomeration of colonial reproductions and representations. Exploiting the social construction of binaries through colonial discourse has been instrumental to the expansionary success of Western hegemony. Africans were imagined as "backward, superstitious, immoral heathens, too ignorant to appreciate the aesthetics of nature because they were considered not altogether too far removed from the wild" (Sharp, 2008). Jan Smuts, who served South Africa's prime minister for two different terms in the twentieth century (1919-1924 and 1939-1948) and as deputy in the coalition government after 1933, asserted the following: "By temperament (Africans) have not much initiative, and if left to themselves and their own tribal routine they do not respond very well to the stimulus for progress" (MacDonald, 2006: 8). White domination and consequent black disenfranchisement were dependent upon development discourses that naturalized racial and cultural inferiority.

The emergence of potentially new development discourses directly impacts, and is consequently shaped by, the geographies of the apartheid system (King, 2007). The apartheid system was historically buttressed by laws such as the Glen Grey Act of 1894 (implementation spearheaded by Cecil Rhodes, Prime Minister of Cape Colony), which imposed a labor tax to encourage industrial employment. The most important legislation was the Native Lands Act (NLA) of 1913. This law enforced the removal of $80 \%$ of the black population onto 13\% of South African land. The Bantu Authorities Act of 1951 during the apartheid era (1947-1991) further entrenched these laws of separate development by legalizing a hostile dispossession of land that displaced African populations onto designated Bantustans. Large-scale evictions of indigenous farmers characterized the apartheid regime. Black South Africans could not be citizens or fully participate in the political process.

The Bantu Authorities Act set off a domino effect of policies which served to "develop" and educate black South Africans to be nothing more than low wage earning laborers for whites (Bantu Education Act 47, 1953). Lacking the ability to fully participate in the political process, black South Africans petitioned for laws of equality. 
This became particularly problematic with the Suppression of Communism Act (1950), as the police were allowed to arrest anyone suspected of creating hostility between Europeans and non-Europeans. Bans of political organizations characterized government rule. The apartheid regime continued to radically transform the political and social landscape of rural South Africa, establishing tribal, regional, and territorial authorities that empowered hand-selected chiefs that served at the interest of the colonial power.

The transformative powers of apartheid extended beyond the sociopolitical, transforming the cultural, environmental, and economic landscape as well. The Bantustans achieved its design of divide and rule by shifting populations and boundaries according to different language groups and colonial conceptualizations of culture and ethnicity. Through highly concentrated processes of marginalization, local ecology endured greater human activity and environmental degradation due to forced overcrowding. Livelihoods, the capabilities, assets (stores, resources, claims and access) and activities required for a means of living, (McCusker and Carr, 2006) were jeopardized as local communities were alienated from using much-needed natural resources. The result could have been anticipated: marginalization led to increased environmental degradation in the form of soil erosion, but was blamed on destructive indigenous land practices rather than increased populations living on shrinking parcels of land (Fabricius and de Wet, 2002).

"The discursive gaze and institutionalized practices of colonial science and administration often went hand-in-hand to construct peasants as environmental destroyers, justifying their removal, restriction or re-education" (Fairhead et al., 2012: 249; Leach and Mearns, 1996, Beinart and McGregor, 2003; Adams, 2004). Some government officials eventually addressed the decaying living conditions of the homelands, and two decades later the apportionment of land was increased to $13 \%$ in the Native Trust and Land Act (1936). The shift in land policy, however, had little to do with humanizing black South Africans. Rather it was motivated by a concern regarding the reproduction of labor (Moyo, 2008). Later, the government introduced a Betterment Scheme (1939) to combat perceived soil erosion by reducing grazing land and the number of cattle that black pastoralists could own (Beinart, 2013), which required further coercive measures and the production of artificial partitions (Robbins, 2011) to protect agricultural production. Deviation from the scientific norm of Western conservation necessitated intervention and 'development' strategies (Briggs and Sharp, 2004; Escobar, 1995) that continue to marginalize black South Africans today.

Placing black Africans "on the geographical margins of white farming" (Jeeves and Crush, 1997: 21) fits along a historical continuum reflecting land transformation policy benefiting intransigent agricultural producers demanding cheap, servile and accessible labor. Artificially high farm prices, low costs and protection from imports encouraged farmers to scale-up agricultural production but on semi-arid land that was better suited to pastoralism (Jeeves and Crush, 1997). The requirement of greater inputs placed greater stress and demand on the land and its laborers, yielding both concerns regarding the long-term environmental and economic sustainability of the project, and portents for future maintenance of land use policy change and racially based social relations on the farms. Laws, policies and legislation favored large-scale agricultural production, which provided the structure for capital accumulation to occur (according to a review in 1933, approximately 80 'acts' had been passed since 1910). Monopoly 
control, financial viability, and the survival of white southern African farmers were predicated upon draconian measures of discipline, surveillance, coercion, and violence to mobilize a black labor force (Jeeves and Crush, 1997).

Since the state reduced agricultural subsidies in the 1990s, many of these farms have been transformed into private wildlife conservation enclosures that are mixed farming (wildlife and livestock, including intense breeding of wildlife species), consumptive (biltong, trophy hunting), or non-consumptive (ecotourism) operations. "Re-wilding" farms that formerly produced cattle or maize contribute significantly to the percentage of South African land now under protection today (Snijders, 2012). As farming landscapes are transformed into consumptive (and extractive) 'wilderness' landscapes of various kinds, new spatial enclaves are being created through practices of enclosure, leading to new forms of inclusion and exclusion, and with them new groups of 'surplus people' (Spierenburg and Brooks, 2014). In the decade following the end of apartheid, approximately two million farm dwellers were displaced, which is more than the number displaced in the ten years preceding democracy (Lahiff, 2007). Brooks and Kjelstrup (2014) researched a group of 12 farm owners who made the commercial decision to develop their combined properties as an ecotourism destination in 1996. This case study speaks to the "incommensurability of two very different conceptions of land - the commercial version versus the interior, 'lived' geography of people like the farm dwellers, as well as to the postapartheid state's inability to take account of the latter" (Brooks and Kjelstrup, 2014: 252). What they discovered was that despite the Extension of Tenure Security Act (1997), which was passed with the intention of ensuring greater tenure security for farm dwellers and farm workers, the rights of the farm dwellers were secondary to those of the white landowners who could determine what would happen on their property (Brooks and Kjelstrup, 2014). During the land claims process one landowner impounded some of the farm dweller cattle to intimidate them into moving off the land (Brooks and Kjelstrup, 2014).

Game farmers, mindful of the socioeconomic contradictions that have come with democratic transition, will accommodate adjacent communities with temporary or full-time employment, protein from hunts, and development assistance such as tertiary bursaries, local school renovations, and the provision of health clinics.

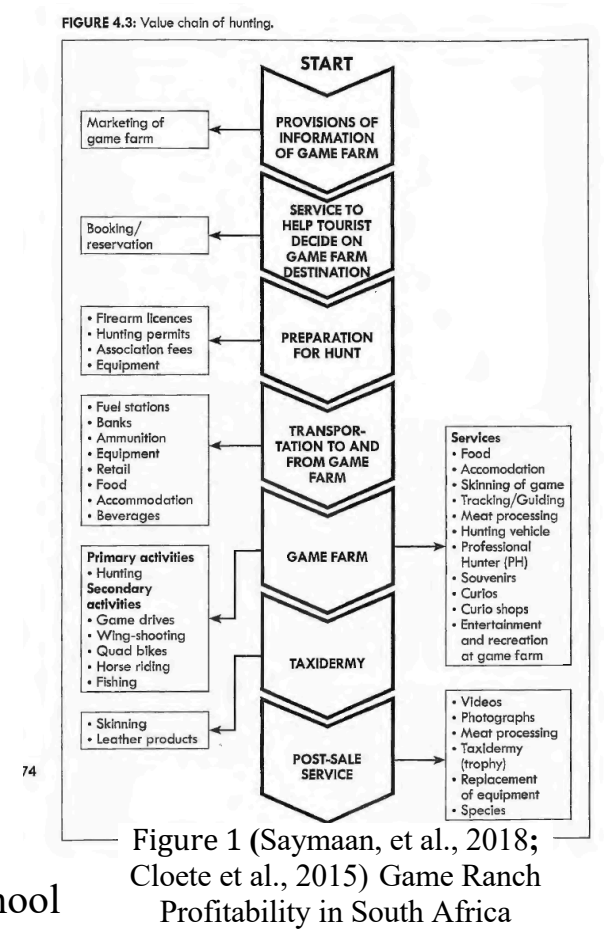

"So it's recognized. And the private industry is buying into it for their own, not necessarily for the social good, but for their own good they recognize if they don't play ball, if they don't bring in communities, in the long term they're going to lose. We've got a growing population, a population that's getting frustrated and things like that" (personal communication NGO, 2018). 
South Africa's green economy emerged out of this growing sense of socioeconomic responsibility and as a tool to legitimize the growing trophy hunting industry. Wildlife Ranching South Africa (WRSA) led the charge beginning in 2005 by merging existing provincial bodies representing farmers that had been operational for thirty years at the regional level, and represents 1500 members of 9000 registered game ranches in the country (Snijders, 2012). They lead the discursive charge oftentimes by citing the value chain of trophy hunting (Figure 1).

Despite land reform initiatives, the majority of these ranches remain white owned. In this way, "private game farming cannot be seen in isolation from pressing questions around land, property, and agrarian futures" (Spierenburg and Brooks, 2014: 151). The industry's ability to adapt to neoliberal policies and discursively engage the pillars of conservation (economic, environmental, and social) has ensured that "white agricultural capital remains virtually intact through the reproduction of racially-based class relations in the countryside" (Hendricks et al., 2013: 19). Kamuti (2015) draws our attention to South Africa's green economy and the discourses and organizations buttressing it. His paper alludes to how white South Africans claim Africanness but do not apply an Afrocentric strategy for conservation and socioeconomic development. Nor do they attend to ameliorating the racial injustices of the past. Kamuti's argument serves as a catalyst for further inquiry, namely the politics of identity and advancement of neoliberal discourses in relation to the private accumulation of land, wildlife, and wealth in South Africa.

\section{Methods and Data Collection}

Understanding South Africa's settler past is fundamental to interpreting South Africa's current trophy hunting industry. This paper thus draws on previous historical research conducted initially as a Master's student at the University of Missouri (20122014). At that time I researched the co-management of natural resources using political ecology and a post-colonial lens to understand the contradictions and limitations of wedding conservation and land reform with spatial development initiatives. This chapter (paper) also draws on my life and work experience in South Africa (2003-2005), as I lived for two years on the edge of the Kalahari in the Northwest Province. Here I became intimately acquainted with the unresolved racial residue of colonialism and apartheid.

Ethnographic data collection began when I attended Safari Club International's Annual Hunter's Convention (2016). I used this consumer space to meet South African game farmers, who put me in touch with still other industry acolytes. The snowballing technique (Johnson, 2014) allowed easier access to a community generally very distrustful of critical social scientists. Building on this network, I was able to create a list of potential farms to visit later in South Africa, which occurred for six weeks in the summer of 2018 (July-August).

To collect data I used a combination of qualitative and ethnographic approaches (Creswell and Tashakkori, 2007), including participatory and non-participatory observations (Clifford et al., 2016), semi-structured interviews (Longhurst, 2003), unstructured interviews (Morse and Corbin, 2009), and discourse analysis (Ahmadvand, 2011; Waugh et al., 2016; Sharp, 2008; Fairclough, 2013; Kamuti, 2015). In addition to interviews and observations, I analyzed discourses found on online hunting magazines, websites, and social media platforms. Furthermore, I reviewed government legal documents and state reports, pro-trophy hunting and wildlife ranching NGO reports, 
documentary films, conference videos, and press releases, international environmental reports, regulations and statements, and current news and relevant peer-reviewed journal articles.

I used a digital recording device to interview research participants. I transcribed interviews immediately afterward on Microsoft Word to ensure greater accuracy and identify areas in need of clarification. I uploaded these transcriptions into Nvivo for analysis, at which point I was able to identity the major discursive themes found in this paper: colonial epistemologies, identity politics, threats to the industry, and a marketbased approach to conservation.

Personal communications included the following actors: a) State government (Department of Environmental Affairs (DEA) and South Africa National Biodiversity Institute (SANBI)); b) Non-governmental organizations such as Endangered Wildlife Trust (EWT), Conservation Action Trust, TRAFFIC, Wildlife Ranching South Africa (WRSA), Professional Hunters Association of South Africa (PHASA), Custodians of Professional Hunting and Conservation (CPHC), Predators Breeding Association of South Africa (PBASA), and South African Hunting and Game Conservation Association (SAHGCA); and c) taxidermists, wildlife ranchers, game farmers, game reserve managers, professional hunters, international hunters, game capture teams, veterinarians, and lion breeders.

Please note that I often cite literature throughout each section that reflects my data and/or findings to which I'm in agreement. I use literature throughout this chapter to supplement my data, meaning that selected literature not only helps frame the analysis of my data, but it also lends my findings additional credence and support.

\section{A Market Based Approach}

Colonial assumptions that poor African stewardship of land leads to environmental degradation are highly relevant to the legitimization of trophy hunting as a strategy for development today, as they justify the ongoing privatization of conservation and inform "market driven" approaches that will encourage people (read: black indigenous and non-indigenous Africans) to "value their surroundings"" (Igoe et al., 2010). According to economic principles, local "communities" will reap socioeconomic benefits from wildlife tourism that will reduce human-wildlife conflict and naturally deter rural communities from detrimental land use practices such as cattle grazing, natural resource extraction, overhunting, poaching, and commercial development. Despite efforts to "develop" black rural communities, conservation remained exclusive and reproduced uneven socioeconomic results (Kepe et al., 2005; McCusker et al., 2015). Eventually these outcomes were realized, but through a neoliberal lens.

Neoliberal conservation's core axiom is that in order for natures to be "saved," acts of "nature saving" must be imbued with profit potential or else there is little incentive for rational actors to pursue it (Buscher et al., 2012).

Myriad contradictions of conservation manifested around the world, namely increased dispossession, displacement, economic disparity, rising unemployment, and poor environmental outcomes. In response, global practitioners eventually presented more inclusive, participatory, and community and rights-based conservation initiatives. 
International practitioners and policy makers prepared and commissioned the World Conservation Strategy (1980) and the Bruntland Report (1987), emphasizing the link between poverty and conservation and the need for a synergy between conservation and development (Cundill et al 2013). Later, the Rio Earth Summit (1992) crystallized the notion of community involvement in natural resource management at a global policy level (Cundill et al., 2013) with the development of the Convention on Biological Diversity (CBD) (1992), which is used today as the international instrument that binds and encourages nation-states, to which South Africa is signatory, to have detailed biodiversity conservation strategies (SANParks, 2012; DEAT, 1997). As part of this arrangement, South Africa has obligated itself to protecting $25 \%$ of its land (SANBI, 2014), but this has come with increasing competition, conflict, contradictions, and a new set of strategies that result in the privatization of the public good.

Game farmers and the industry alike insulate game farm conversions within global policies, all of which serve to rescale the implementation of development policies interlinking multiple sustainability goals. National governments challenged with integrating these policies in rural areas generally lack allocation capacity, leading to devolution of natural resource management and its predictable failures, which are then followed by the privatization of wildlife and other resources typically benefiting the landed class. The alchemy of devolved public services, coupled with deregulation and the challenge of shrinking agricultural subsidies and new labor laws ensuring a minimum wage, incentivized commercial farmers to transition to wildlife conservation. Other reasons for the modern rise in wildlife management and trophy hunting include South African law which facilitated game ranching as an industry, declining wool prices, protein production to meet the growing needs of a growing population, and international narratives of conservation and sustainability (Carruthers, 2008). Perhaps the most significant legislation was the Game Theft Act (1991), which ultimately gives legal and private ownership of wildlife to landowners (Snijders, 2015) so long as they provide suitable fencing (Taylor et al., 2016). Given that the fences enclose wildlife satisfactorily, landowners were eligible for a Certificate of Adequate Enclosure (CAE) from each of the provinces, which is a move that entitles them to subsidies as well as other benefits (Carruthers, 2008). More recently, a new amendment to the Animal Improvement Act (AIA) (1998) lists a number of wild animals as farm animals, including lions, mountain zebras, giraffes, white and black rhinos, and Cape buffalos. Reclassification reflects the reach of the wildlife industry lobby and signifies a strengthened commitment to the private mode of conservation. NSPCA director states that this new development "has many worrying implications" (conservation.co.za, retrieved October 2019) for animal welfare, which is currently regulated according to restrictions outlined in the National Environmental Management Biodiversity Act (NEMBA) (2004). For a country that already receives a great deal of criticism and questions pertaining to the "wildness" and ethical treatment of nonhumans raised and killed behind fences, this development may have economic implications as well.

\section{Data}

The trophy hunting industry recognizes it has an image problem. They steadfastly safeguard their practices against the rebuke of 'antis' through discouraging fellow hunters 
from posting online photos that can be construed as insensitive. A few research participants recognized that the term trophy carries negative connotations and consequently seek an alternative term that green washes the violence of hunting yet captures its ecological and economic benefits. For example, Namibian hunting NGOs encourage the term "conservation hunting" (SCI convention, 2018), while trophy hunters in the US, South Africa, and elsewhere, refer to trophy hunting as "sustainable use conservation." Shifts in semantics signal a growing concern amongst practitioners that their livelihoods are under assault. And understandably so. They are quite literally competing for donor dollars and power against non-governmental organizations (IFAW, HSUS, Panthera) that advocate non-consumptive (photographic safaris, bush walks, etc. that generally occur in national parks) (Saayman et al., 2018). Social media users from the West, according to interviews, are the number one threat to the industry, which is why practitioners request that international trophy hunters exercise good judgment when posting photos of their kills online. For example:

"Avoid images showing blood and tongue; bullet entry or exit; arrows; standing or sitting on the animal; posing with your animal or birds as they are a prop and you are the conquering hero; or hanging from the back of a truck, etc." (http://www.cphc-sa.co.za/).

"Those of us who care about hunting can no longer afford to dismiss the fact that some of the images we share and post on social media are, at a minimum, having a negative effect on the public image of hunting, if not providing animal rights and anti-hunting groups ample cannon fodder with which to fire back at us." http://www.cphc-sa.co.za/.

"As hunters, we need never apologize for all that we do and what sportsmen have done for wildlife and wildlife habitat conservation. We do however have an obligation to demonstrate respect for the hunted and the sensitivity of others who also care about wildlife." http://www.cphc-sa.co.za/

Chief among their concerns are displays of superfluous violence, stereotypical masculine behavior rooted in colonialism, and insensitive objectification. Every hunter and game farmer I encountered in my research abhorred this type of behavior, and referred to these hunters as a minority of 'bad apples' that paint an unfortunate and inaccurate portrait of the industry. Many in the wildlife industry operate under good intentions and the sincere belief that trophy hunting is a necessary wildlife management tool to protect habitat from human development and poaching._Hunters exclaim that there is no one size fits all scenario to conservation, and that depending on time and place, conservation requires an 'all in' type approach, similar to energy advocates who argue for the utilization of alternative or renewable energy sources and fossil fuels to meet global demand. Industry advocates argue that an 'all in' approach acts as a safeguard against times of drought, market volatility, and inflation. An 'all of the above' approach means that there are circumstances and places that suit the spectrum of consumptive and non-consumptive use, which is an opinion shared by WWF, IUCN, US Fisheries and Wildlife (USFW), and international safari organizations such as Safari Club International (SCI). These organizations not only normalize the killing of nonhumans to meet development ends, but 
also may entrench the racial and colonial character of conservation. At the same time, we can observe how the collective of international and national organizations undergo temporary strains and transformations according to scale and identity.

\section{Race, Identity, and Belonging \\ “Hunting 'nature' is a commodity that anchors a past nationalist masculine hierarchy in a reciprocal relationship to game on privately owned land and collapses belonging into ownership" (Goodrich, 2015: 1).}

While interviewing the world's most controversial and outspoken rhino farmer, John Hume, I discovered a meme circulated regularly amongst like-minded international trophy hunters and South African wildlife ranchers. The meme depicts black Africans, dressed in traditional clothes, sitting in a circle discussing the management of American white-tailed deer (Figure 2).

According to the rhino farmer, the meme perfectly demonstrates how American conservationists and professional practitioners wouldn't appreciate Africans, having presumably never set foot on American soil, weighing in on their wildlife decisions. He was quick to point out that Americans and Europeans alike couldn't possibly understand the complex cultural, social, and ecological issues that Africans face everyday. Despite their ignorance, in his view, these interlopers stubbornly insist on imposing their ideas and solutions. In short, their interference is ignorant, elitist, hypocritical, and colonial.

What's of particular note are the ways in which identities are politicized to scale. McDermott (2005) notes how conservationists may take on a "larger scale of citizenship." While McDermott's conclusion was made in the context of transfrontier conservation, we can apply the concept here. In this instance, white conservationists do not necessarily identify with the nation-state but rather scale up their identity to the African continent. Additionally, interviews revealed how white farmers, though European in descent and epistemology, identified with being African and victim to Western hegemony. Culturally appropriating Africanness legitimizes belonging and ownership, for as "Africans" they have every right to own and profit from privatized conservation. Ironically, while white farmers in South Africa complain of a colonial present, they maintain that "the blacks" should "get over" a colonial past. By all appearances, there remains a double standard in terms of sympathy. Additionally, while white farmers identify with Africa as a whole, they carve out distinct racial identities in their home country. In other words, they simultaneously claim to be African, yet their South African identities are distinctly white, Western, and rooted in colonial epistemologies and nationalist ideologies. 
According to Ramutsindela (2012), race in South Africa is entrenched and reproduced through the structure of property relations. In cases of land restitution where the government buys and returns land to historically dispossessed communities, the success or failure of land and resource use and (mis) management is viewed through a racial lens. Below are a few game farmer comments that demonstrate the reproduction of racial stereotypes where black Africans cruelly hunt and poach, and because they "breed" as if in a "factory," will inappropriately and unsustainably utilize natural resources:

"But they take the land and it just goes to ruins. They don't... Say they took this place; no one would look after the animals. If there's no water moved into a camp, it's just sad. I've seen places bought by the government and there's nothing left of it. I'll give you an example. They took a citrus farm in Tzaneen area. The orange trees were cut and burned for wood. There's nothing left. It was a multi-million dollar project there." (Personal communication, 2018)

"The game industry still remains a white industry. There are very few black people that are managing and understanding it in rural Africa. We made more educated ones, but the ones that are living on the ground, it's just a resource on a first come first serve basis."

"That's why I volunteered for them. I'm volunteering to hunt for the Tribal Authority; so that the animals are being killed in a humane way. Not in a cruel way. If you see an old cow, old bull, do selective hunting. And then your quota is done for the year. Otherwise they send the dogs in."

"There's something off with them. I've grew (grown) up with them. I know. I'm not a racist...they're breeding unabated."

"I mean in South Africa the more children you have, the more money you get. It's a factory. For each child that they have they get a grant from the government, more money, more money. So you've got children with children. They must stop it, they must say alright, three children, and from there on we give no more money."

The quotes above indeed signify the ways racism infiltrates the culture of trophy hunting in South Africa today, and speaks to its historically exclusionary character. Durrheim et al. (2011) call the positioning of subjects in racially aligned practices of engagement and conflict race trouble --- how arguments tend to divide society along apparently irreconcilable racial lines as social life becomes racialized. Attempts to disrupt historic power relations appear unfair and ill-conceived, especially when white farmers perspectives have not been uprooted from their colonial epistemologies.

In South Africa's current economic and political crisis, farmers currently perceive threats in security, stock theft, and land restitution claims and expropriation (Carruthers, 2008), meaning that contestations about the establishment of trophy hunting farms then not only touch on nature conservation but the "original status of land and people that belong to the landscape" (Brandt, 2013: p. 18). Geographical territory defines national identity through two distinct hermeneutics: internally (how the national community is 
linked to the land); and externally (how the national community is delimited in relation to other groups) (Foster, 2008). Following the Boer War, a process of South Africanism took place to unionize fractured relations between two white ethnic groups (Boers and imperial British), thus naturalizing heritage and racial identity, and disenfranchising black African populations. Working together, race and nature legitimize particular forms of political representation, reproduce social hierarchies, and authorize violent exclusions (Moore et al., 2003) - all of which I'd argue exemplify the private accumulation of capital through trophy hunting in South Africa today.

For white South Africans, Ndebele (1999) argues:

These lodges offer a 'refuge from living in a black run country': whereas once, the lodge was an "extension of their power, it is now a place where those who feel newly dispossessed of privilege can to go to regain a sense of its possession." The continued relevance and growth of safari tours and game lodges "reaffirms and celebrates a particular kind of cultural power: the enjoyment of colonial leisure."

While attending Safari Club International's Annual Hunter's Convention, I spoke with a game farmer whose comments are relevant to a colonial mindset. When referring to his lodge and land, he said the following:

"The land is rightfully mine. I got it fair and square. It has been in my family for generations."

"When did your family gain ownership of the land?" I asked.

"My family got the land in 1913."

Every South African understands the significance of 1913, and how the Native Lands Act legalized the dispossession of indigenous land and served as a catalyst for the creation of bantustans and separate development. As part of South Africa's land reform policy, if South Africans can prove they lived on a specific piece of land as far back as 1913, using ancestral graves and other cultural markers as evidence, they may file a land claim. A claim can result in the redistribution of land, monetary compensation, and in some cases, the co-management of natural resources. Some land claims resulted in the redistribution of land, but due to market pressures and poor government assistance, black South Africans in some cases have had to sell their land (Henricks et al., 2013). The quote above, however, speaks to the fact that this particular game farmer does not recognize attempts to reverse the NLA of 1913. It illustrates the obstinate character of game farmers who believe they are the rightful owners of the land, despite the fact that the state facilitated land theft.

In the South African winter of 2018, land expropriation without compensation was at the forefront of all discussions. Farmers indicated that international trophy hunters were wary of visiting because of fear of violence and talks of South Africa becoming another Zimbabwe. Due to the highly contentious political issues surrounding land, new land acquisition today is never complete without an historical landownership analysis to preempt and counter land claims, as was the case with Jane Carruthers providing research for the successful game breeder Thaba Tholo (personal communication, 2018). In some cases, landowners have staff that lived on or adjacent to 
their farm for a generation sign documents testifying that their ancestors never lived on the land or were never forcibly removed (personal communication, 2018). Landowners understand that they must use whatever legal mechanisms at their disposal to protect their current and future assets. These legal maneuvers reflect an uneven access to power and knowledge, however, and strengthen the uneven geographic character of South Africa's rural landscape. Landowners in general justify these actions by invoking the lessons of Zimbabwe.

When asked about the government's land policy, farmer responses fit along a spectrum between optimism and Cyril Ramaphosa's ability to forge peace and bridge the political divide, and at the other end frustration and fear of prolonged racial persecution. The following conversation is situated in the latter.

"If you want to be a success in SA, and want to be honest, we are not the right skin color. That's a big thing in South Africa. It's really sad. It's actually sad. But it's fighting against your will."

"In South Africa, you can't sleep without a gun. It's dangerous for farmers at the moment."

Tell me about it. Can you be more specific?

"You have to (practice) self-defense."

"There's a new documentary about it. It's called "Farmlands." Write it down. You need to make a note of it. It hits all the important points. It's huge; it's all over. We're getting a lot of international exposure at the moment, the Boers, for everything that's going on and the government turning a blind eye to it... Well just down the road there's been a murder that way, 10 kilometers there. The owner of here, the daughter's brother-in-law. On this road, about $10 \mathrm{~km}$ down this road."

What do you think these attacks are about?

“Just about race. There's no two ways about it. It's about race. I think at the end of the day they just want to show they can do to us what we did (to them) in the earlier days, apartheid."

The documentary Farmlands advances the myth of white genocide. The picture is grim. Farmers are interviewed and refer to graveyards of their fallen brethren. The statistics of farmer attacks, however, are inaccurate, as data collection methods are inconsistent and politically driven. Disturbed by accounts of white farmers being killed at a rate of one per week, Home Affairs Minister of Australia Peter Dutton Whats App'd one research participant, asking if he wanted a fast track visa to Australia. Under the belief of white genocide, Dutton stated, "From what I have seen they (white farmers) do need help from a civilized country like ours" (https://www.theguardian.com/australianews/2018/mar/14/dutton-considers-fast-track-visas-for-white-south-african-farmers, retrieved November, 2019). His statement reveals how he perceives South Africa: uncivilized. Moreover, the narrative that barbarous people of color will replace white 
people has reached the political shores (un-coincidentally) of another settler colony --the United States. The administration of the US, too, cynically peddles genocidal myths and identity politics for political gain. It's a performance of nationalist pride and solidarity against the rising tide of liberalism and multiculturalism. The threats of multiculturalism, people of color, socialism, and communism are conflated and made universally dangerous to white identity, heritage, and land ownership. The struggle and fear moves beyond nationally bound geographies, and becomes global in scale and severity. Preparation for the day of their arrival to take their land or guns will be met with violence. A game farmer new to wildlife ranching and the trophy hunting industry, said the following:

"The thing is, I don't want to leave my country. I'm going to stand my own. If they want to come, I'm not going to call any racist out, but if they're going to stop three or four buses here with three or four hundred people, and tell me to leave my farm, and say they're going to take this land, I feel sorry for them. I'm really sorry for them. If I catch you on my farm, just like white farmer genocide, wake me up at 3 am with a panga in your hand, I'm not going to kill you, I'm going to shoot off your knees, put you in my bakkie and on the farm where you'll scream like a pig. You wanted to come and slaughter me while I'm alive? I want to see how you going to take it. You're going to try and take me in my sleep. I don't have sympathy for that. I will stand my ground 'til the day I die."

This farmer feels justified to protect himself and his family against an inevitable attack, and fantasizes about violent retribution. Trophy hunting cannot be separated from one's sense of ownership and belonging. The narrative is that they settled and tilled the land, they manage the wildlife, they made the investments, they have "skin in the game", and they are the ones on the ground fighting to save wildlife habitat and species from extinction. No one should be able take this away from them; even if the government ignores them they'll take things into their own hands. In this context we can see how a collective sense of belonging to the landscape may legitimize white landowners to press further to "consolidate and (re)-assert their claims to private property" (Spierenburg and Brooks, 2014).

\section{Threats to a white unified front?}

Alliances amongst white industry players are important in the constant struggle for legitimization, but these relations in South Africa have grown increasingly precarious for a number of reasons. Most controversial amongst them is "canned hunting", which involves breeding lions in captivity and shooting them in small (canned) enclosures. A growing national and international consensus against the captive-bred lion industry, including conservation organizations, conservation and social scientists, policy makers, animal welfare groups, and hunting NGOs, has elucidated the contradictions of organizations such as Wildlife Ranching South Africa (WRSA), which tacitly condones the unethical practices of the South African Predator Association (SAPA).

SAPA currently defended itself in a High Court ruling in Gauteng that favored the NSPCA, highlighting the 2018 arbitrary and illegal lion bone quotas set by the Minister of Environmental Affairs, as well as the department's complete disregard for animal 
welfare in the decision-making process. (https://conservationaction.co.za/mediaarticles/court-victory-for-nspca-over-welfare-of-captive-lions-bone-export/, retrieved August 2019). The Professional Hunting Association of South Africa (PHASA) contradicts itself in its condemnation of canned hunting, for in their denouncement they simultaneously allude to the practice elsewhere as proof of its conservation value, or offer that they shouldn't judge what one farmer does with their wildlife. PHASA was founded in 1976 to optimize wildlife and hunting potential in a sustainable way. They claim to "promote and facilitate the empowerment of all South Africans wishing to participate in the hunting procession and conservation" (Snijders, 2012). Others assert that breeding and killing lions is no different than the utilization of sable or other antelope or plains species. These arguments may appear flimsy, and for obvious reasons. PHASA members are comprised of a number of actors in the wildlife industry, namely land owners and safari operators, who make a lot of money through their partnerships with lion breeders (personal communication, 2018). Some of them are lion breeders themselves, and hold back critique to avoid their own hypocrisy. While PHASA strategically escapes accountability, WRSA unequivocally stands with SAPA and believes that a unified front is necessary to the industry's political and economic survival. A number of research participants revealed that canned hunting was one of two factors that led to a decline in trophy hunter numbers. The fact that fences enclose farms sometimes doesn't set well with hunters looking for an authentic hunting experience. The second is canned hunting, as more traditionally minded hunters believe that canned hunting is unethical and so elect to hunt in Namibia or elsewhere instead.

WRSA's chief concern is that organizational disjuncture threatens the industry's political identity, which hinges upon discourses of social responsibility and ethical hunting. As discussed earlier, according to interviews many in the industry believe that the Western conservation community dictates how "Africa" uses its natural resources. South African wildlife practitioners who agree with the international community are viewed as disloyal. It is an act of betrayal, as they are viewed as succumbing to a topdown colonial conservation political agenda. WRSA and SAPA would rather 'doubledown' on captive lion breeding and canned hunting than address and admit problems that may expose them to further criticism. Essentially any admission of unethical practice can potentially pry open greater space for interrogation and weaken their position (personal communication, 2018).

A group of members within PHASA disagreed with this assessment, exposing an ideological rift in the organization that resulted in a split and the creation of a new hunting organization named Custodians of Professional Hunting and Conservation of South Africa (CPHCSA). Interviews revealed how the hunters that formed their own group are more traditional hunters and English, while the group that remained in PHASA are predominantly Afrikaners. The creation of Kruger could not have occurred without English South Africans reaching out to and connecting conservation with Afrikaner pride and identity. The fact that the fault lines occur now between both these groups, who have a very problematic past, deserves further research. Those who decided to stay with PHASA opined that the whole "canned issue" was over-exaggerated, and charged their new organization rivals with moral grandstanding for the purposes of economic gain against a heavy field of competition (https:/www.farmersweekly.co.za/animals/gameand-wildlife/sa-hunting-poised-for-growth/, retrieved August 2019). 
PHASA's constitution legitimizes the profit motive through the sustainable utilization model but encounters its own contradictions in the context of supporting canned hunting. This particular brand of "conservation" in no way contributes to "preserving the national heritage of South Africa," which is one of the goals outlined in their mission statement. WRSA's support of SAPA and the captive lion industry directly contradicts the purpose of "enhancing the reputation of the industry, locally and globally,"(https://www.wrsa.co.za/goals-who-is-wrsa/) as the International Council for Game and Wildlife Conservation (CIC) (the largest pro hunting organization in Europe), African Professional Hunter's Association, Dallas Safari Club, and SCI have all condemned canned hunting of lions. Here's a quote from SCI:
"An unfortunate consequence is the setup or "canned" lion hunt, in which a captive lion is presented to an unsuspecting client. Such a "hunt" can be impossible for the client to detect if well-orchestrated. Since the beginning, SCI has had a policy against accepting setup lions for the Record Book, and has never knowingly done so" (www.scirecordbook.org/species/index.cfm, retrieved October 2018).

CPHCSA abides by fair chase ethics and seeks to disassociate themselves and the hunting industry in its entirety from captive lion breeding (CLB) and canned hunting. The CIC and pro-hunting NGOs such as the Dallas Safari Club (DSC) have offered discursive and financial support to CPHSCA (personal communication, 2018). DSC and SCI have clearly emphasized that they will not allow a safari outfitter who trades in canned hunts on their market room floor, as they too are mindful of protecting the reputation of the trophy hunting industry from being associated with the objectively cruel and unethical practices that sustain and produce canned hunts. These practices are worth reviewing.

Firstly, cubs are separated from their mothers to stimulate the females back into estrus, which is not uncommon to industrialized food production facilities such as CAFOs. Secondly, captive-bred lions are hand-raised and consequently do not fear humans. One lion-breeder framed this as a more exciting encounter for the hunter because a lion that does not fear humans is potentially "more dangerous" (game breeder interview, 2018). This type of illogic defies decades of wildlife science research that required the habituation of nonhuman species, such as nonhuman primates, for data collection purposes. While habituation does not remove the danger of a wild, domesticated nonhuman, especially a predator species, it builds a relationship of trust whereby the nonhuman is disarmed and not as fearful that it will be attacked. Lions in national parks are habituated to cars, but humans on foot become "game" to them. [I'm unaware of humans who have navigated these boundaries who refer to this life and death scenario as a "game."] If the lion trusts that a human will do no harm, particularly a hunter stalking on foot, it is less likely to protect him/herself. She/he will most likely associate the human with receiving food or accompanying them on walks. In some cases breeding farms falsely advertise their operations as sanctuaries and accept money from unwitting volunteers from abroad who believe they are providing a much-needed service (EWT, 2016). In their service to the lions they pet cubs or walk with the adults. Additionally, upon release into the "wild", captive bred lions are almost always immediately hunted and killed (the period of time a lion must be in its new surroundings before it's hunted depends upon the provincial conservation authority, which in the 
Northwest Province is 96 hours). In this way the captive-bred lion does not have a sporting chance to elude the hunter. Lion breeders argue that a lion that is alone in a foreign environment and not killed right away will struggle to survive, meaning that the most humane and ethical approach is to actually harvest the lion soon after release (personal communication with lion breeder, 2018). In this way the lion will not suffer. How precisely this practice may be interpreted as "fair chase", ethical, or necessary to conservation is difficult to fathom.

"Yeah the catalog wild thing. And they send you an email and there are like 20 lions, the price on each one, and you choose which one you want. And they'll dart it and put it in a camp for you to shoot. They don't understand what damage that has done, the whole of South Africa, not just the hunting industry. The tourist industry is being tarnished by it."

One interview of a lion breeder echoed the discourse that "without breeding lions in captivity there would be no wild lions." According to the conservation community, however, breeding lions in captivity holds zero conservation value (Taylor et al., 2016). The largest hunting organization in South Africa, South Africa Hunting and Conservation Association (SAHCA), echoes this sentiment:

"There's no contribution to conservation whatsoever in that practice. The only contribution is for the individual that wants to hunt the lion. If you want to shoot a lion rather go and shoot those than take one from nature because the damage you may do in nature by taking one out one single male lion may be bigger than killing that one. That's the only conservation value. It's economic, it's making money out of it, nothing more."

\section{Conclusion}

This paper highlights the reasons why South Africa remains a "preferred hunting destination" (PHASA, 2016) despite many of the trophy hunting industry's internal tensions, conflicts, and ethical dilemmas plaguing the production and commodification of nature. This chapter expands the commodification of nature theme, noting the results in devaluing some species in favor of others, and the uneven natures that evolve thus contradicting the tenets of conservation. Despite efforts and well-intentioned individuals, the nature of nature conservation in South Africa remains colonial. I argue that the reasons for this are manifold, more specifically rooted in hunter expectations, marketing strategies, neoliberalism, failures of land reform, and the ability of the trophy hunting industry to foster relations with state and international conservation.

Safari Club International often cites an IUCN report, which states the following:

"Legal, well regulated trophy hunting programs can, and do, play an important role in delivering benefits for both wildlife conservation and for the livelihoods and wellbeing of indigenous and local communities living with wildlife" (www.iucn.org, retrieved November 2018). 
Anchoring the trophy hunting industry are not only the IUCN, but CITES (though many international trophy hunters and South African practitioners frequently complain that this organizational body, like many other Western organizations, does nothing good for conservation) and the international conservation community, such as WWF-SA. Additionally, national agencies such as the South African Department of Environmental Affairs (DEA) advocate the integration of the green economy into sustainable international development initiatives such as the Sustainable Development Goals (DEA, 2016). DEA states on its website that "other significant drivers of the biodiversity economy include trophy hunting and the associated industry of taxidermy, sale of live game, and sale of game meat." The website elaborates on the value it can bring and how biodiversity can be used as a "vehicle for social upliftment" (www.environment.gov.za, retrieved July 2019). Not dissimilarly, WWF-South Africa advocates a "multi-pronged conservation approach" that includes trophy hunting, which they believe is a better alternative to "cattle grazing and converting habitats for farming" (wwf.panda.org, retrieved July 2019).

"Wildlife-related activities such as safaris and hunting were associated with affluence, and by the 1950s, owning wildlife land was still a badge of exclusivity and social standing" (Brandt, 2013). "It is the location of race which emerges from struggles where subjects position themselves, and are positioned, in ecologies of belonging. This dialectic of identity formation, suffused with power, is crucial to appreciating the racialization of political terrain that forcibly excludes and includes" (Moore et al., 2003: 44). For South Africa to remain the number one trophy-hunting destination in Africa, industry practitioners deflect attention away from the racial reality encompassing trophy hunting. The boards of these organizations and their members are predominantly male and white (Snijders, 2012), and racially biased.

"The way I'm telling you now is the way I see it. When they took over the country it was a very wealthy country. I mean in 1982 our currency was equal to the dollar. And you know what the currency is at the moment." (Personal communication with game manager, 2018)

The reality is that despite economic and environmental arguments, trophy hunting continues to produce spatial processes of class segregation by race.

Game farm ownership as a status symbol in South Africa is historically based (Snijders, 2012). To maintain relevance and white livelihood production, discourses operate simultaneously at different times and multiple scales. Specifically, white South Africans identify politically as African when they perceive that the Western conservation community condemns them or restricts their ability to sustainably utilize nonhumans for profit. The industry says, "Let Africa speak for herself," which inherently carries claims of an African belonging. White South Africans are also motivated by a sense of belonging at the national level, which is rooted in colonialism and attitudes of superior stewardship of land. Game farmers' identity and their claim to the land sharpen when faced with real and perceived threats of land expropriation and racially-motivated farm attacks. In its infancy, South Africa was able to resolve its historically rooted internal rifts between two white ethnic groups through conservation. Kruger National Park is testament to this alliance. 
Today, however, conservation may be at the root of new rifts unless the industry is able to eradicate the largest blight on the international trophy hunting safari circuit: canned hunting and captive lion breeding. We need to ask ourselves how the idea that nonhuman animals must die to guarantee the future survival of Africa's most iconic and threatened species continues to infiltrate and influence powerful state agencies. This abusive practice, among others (see chapter 2), initially emerged from discourses of scarcity (the lions are disappearing because of habitat loss and poaching!), but perhaps more perniciously through a seemingly benign neoliberal market based approach. Indeed, conservation should be understood in terms of manufacturing a scarcity that serves to increase consumer demand. In this context, more attention needs to be paid to capital's co-optation of conservation. The contradiction is that core economic countries and institutions such as the World Bank have prescribed capitalism to save the planet from capitalism with capitalism (Igoe et al., 2010). The integration of neoliberal principles at the point of South Africa's democratic transition meant that land in South Africa had to be re-imagined and repaired, or spatially fixed (Harvey, 2001; Fairhead et al., 2012). Investing in the creation of protected nature areas by white landowners served as a response to indebtedness but more importantly identity and their sense of belonging in the broader political economic crisis. White South African attitudes and approaches are not entirely dissimilar to their settler brethren in the United States, where American trophy hunters advance a politics of difference to justify killing in the name of nature (chapter 1).

\section{Works Cited}

Adams, W.M. (2004) Against Extinction: The Story of Conservation. London: Earthscan.

Ahmadvand, M. (2011). Critical Discourse Analysis An introduction to major approaches. Jurnal Ilmiah Dinamika Bahasa dan Budaya, 5(1), 82-90.

Beinart, W. (2000). African history and environmental history. African Affairs, 99(395), 269-302.

Beinart, W. (2013). The Rise of Conservation in South Africa: Settlers, Livestock, and the Environment, 1770-1950. Oxford Press.

Beinart, W., \& Coates, P. (1995, 2002). Environment and history: The taming of nature in the USA and South Africa. Routledge.

Beinart, W., \& McGregor, J. (2003). Social history and African environments. James Currey, Ohio University Press and David Philip.

Berghoefer, U., Rozzi, R., \& Jax, K. (2010). Many Eyes on Nature: Diverse Perspectives in the Cape Horn Biosphere Reserve and Their Relevance for Conservation. Ecology \& Society, 15(1). 
Bezeuidenhout, Roelof. (August 17, 2019). SA hunting poised for growth. Retrieved from https://www.farmersweekly.co.za/animals/game-and-wildlife/sa-hunting-poisedfor-growth/

Bluwstein, J., \& Lund, J. F. (2018). Territoriality by conservation in the Selous-Niassa Corridor in Tanzania. World Development, 101, 453-465.

Brandt, F., \& Spierenburg, M. (2014). Game fences in the Karoo: reconfiguring spatial and social relations. Journal of Contemporary African Studies, 32(2), 220-237.

Brandt, F. (2013). Tracking an Invisible Great Trek: an ethnography on the re configuration of power and belonging on trophy-hunting farms in the Karoo.

Braun, B. (1997) 'Buried Epistemologies: The Politics of Nature in (Post)-colonial British Columbia', Annals of the Association of American Geographers, 87: 1, 3 - 31

Briggs, J., \& Sharp, J. (2004). Indigenous knowledges and development: a postcolonial caution. Third World Quarterly, 25(4), 661-676.

Brockington, D. (2002). Fortress conservation: the preservation of the Mkomazi Game Reserve, Tanzania. Oxford: International African Institute in association with James Currey.

Brockington, D., \& Duffy, R. (2010). Capitalism and conservation: the production and reproduction of biodiversity conservation. Antipode, 42(3), 469-484.

Brooks, S., \& Kjelstrup, L. (2014). An anatomy of dispossession: post-apartheid land ights and farm dweller relocation in the context of a private game reserve initiative, northern KwaZulu-Natal. Journal of Contemporary African Studies, 32(2), 238-257.

Buscher, B., Sullivan, S., Neves, K., Igoe, J., \& Brockington, D. (2012). Towards a synthesized critique of neoliberal biodiversity conservation. Capitalism Nature Socialism, 23(2), 4-30.

Carruthers, J. (1989). Creating a national park, 1910 to 1926. Journal of Southern African Studies, 15(2), 188-216.

Carruthers, J. (1995). The Kruger National Park: a social and political history. University of Natal Press.

Carruthers, J. (2007). South Africa: A World in One Country. Conservation and Society, 5(3), 292-306. 
Carruthers, J. (2008). "Wilding the farm or farming the wild"? The evolution of scientific game ranching in South Africa from the 1960s to the present. Transactions of the Royal Society of South Africa, 63(2), 160-181.

Carruthers, J. (2011). Pilanesberg National Park, North West Province, South Africa: uniting economic development with ecological design-a history, 1960s to 1984. Koedoe, 53(1), 00-00.

Castree, N. (2004). Differential geographies: place, indigenous rights and local resources. Political geography, 23(2), 133-167.

Clifford, N., Cope, M., Gillespie, T., \& French, S. (Eds.). (2016). Key methods in geography. Sage.

Creswell, J. W., \& Tashakkori, A. (2007). Differing perspectives on mixed methods research.

Corson, C. (2011). Territorialization, enclosure and neoliberalism: non-state influence in struggles over Madagascar's forests. Journal of Peasant Studies, 38(4), 703-726.

Cundill, G., Thondhlana, G., Sisitka, L., Shackleton, S., \& Blore, M. (2013). Land claims and the pursuit of co-management on four protected areas in South Africa. Land use policy, 35, 171-178.

Custodians of Professional Hunting and Conservation-South Africa retrieved October 2018 from http://www.cphc-sa.co.za/

Department of Environmental Affairs Biodiversity and Conservation retrieved September 2019 from https://www.environment.gov.za/branches/biodiversity conservation

Dickson, B., Hutton, J., \& Adams, W. A. (Eds.). (2009). Recreational hunting, conservation and rural livelihoods: science and practice. John Wiley \& Sons.

Duffy, R., \& Moore, L. (2010). Neoliberalising nature? Elephant-back tourism in Thailand and Botswana. Antipode, 42(3), 742-766.

Durrheim, K., Mtose, X., \& Brown, L. (2011). Race Trouble: Race, identity and inequality in post-apartheid South Africa. Lexington Books.

Escobar, A. (2011). Encountering development: The making and unmaking of the Third World. Princeton University Press.

Faasen, H., \& Watts, S. (2007). Local community reaction to the 'no-take'policy on fishing in the Tsitsikamma National Park, South Africa. Ecological Economics, 64(1), 36-46. 
Fabricius, C., \& de Wet, C. (2002). The Influence of Forced Removals and Land Restitution. Conservation and mobile indigenous peoples: displacement, forced settlement, and sustainable development, 10, 142.

Fairclough, N. (2013). Critical discourse analysis: The critical study of language.

Fairhead, J., Leach, M. \& Scoones, I. (2012). Green Grabbing: a new appropriation of nature?. Journal of Peasant Studies, 39(2), 237-261.

Frey, N., \& George, R. (2010). Responsible tourism management: The missing link between business owners' attitudes and behaviour in the Cape Town tourism industry. Tourism management, 31(5), 621-628.

Foster, J.A. (2008). Washed with sun: Landscape and the making of white South Africa. University of Pittsburgh Press.

Giampiccoli, A., van der Merwe, P., \& Saayman, M. (2013). The impact of private game farms on local community development.

Gregory, D. (2004). The Colonial Present: Afghanistan, Palestine, Iraq (pp. 1-15). Blackwell Publishing.

Goodrich, A. (2016). Enacting and stabilizing the nature of colonial history through hunting in the South African Highveld. Journal of Contemporary African Studies, 34(1), 22-39.

Harvey, D. (2001). Globalization and the "spatial fix". Geographische Revue, 2, 23-30.

Hendricks, F., Ntsebeza, L., \& Helliker, K. (2013). The promise of land. Johannesburg: Jacana Media.

Hirschman, E. C. (2003). Men, Dogs, Guns, and Cars--The Semiotics of Rugged Individualism. Journal of Advertising, 32(1), 9-22.

Hutton, J., Adams, W. M., \& Murombedzi, J. C. (2005, December). Back to the barriers? Changing narratives in biodiversity conservation. In Forum for development studies (Vol. 32, No. 2, pp. 341-370). Taylor \& Francis Group.

Igoe, J. (2004). Conservation and globalization: A study of national parks and indigenous communities from East Africa to South Dakota. Thomson/Wadsworth.

Igoe, J., Neves, K., \& Brockington, D. (2010). A spectacular eco-tour around the historic bloc: Theorising the convergence of biodiversity conservation and capitalist expansion. Antipode, 42(3), 486-512. 
IUCN Commission on Environmental, Economic, and Social Policy: SULi Briefing Paper - Informing Decisions on Trophy Hunting. Retrieved from https://www.iucn.org/commissions/commission-environmental-economic- and-

social-policy/our-work/sustainable-use-and-livelihoods/resources-andpublications/suli-briefing-paper-informing-decisions-trophy-hunting

Jeeves, A. H., \& Crush, J. (1997). White farms, black labor: the state and agrarian change in Southern Africa, 1910-50. James Currey Ltd.

Johnson, T. P. (2014). Snowball sampling: introduction. Wiley StatsRef: Statistics Reference Online.

Karp, Paul. (March 14, 2018). Australia considers fast-track visas for white South African farmers. Retrieved from https://www.theguardian.com/australia news/2018/mar/14/dutton-considers-fast-track-visas-for-white-south-african farmers

Kamuti, T. (2015). A critique of the Green Economy-approach in the wildlife ranching sector in South Africa. Africa Insight, 45(1), 146-168.

Kepe, T., Wynberg, R., \& Ellis, W. (2005). Land reform and biodiversity conservation in South Africa: complementary or in conflict?. The International Journal of Biodiversity Science and Management, 1(1), 3-16.

King, B. H. (2007). Conservation and community in the new South Africa: A case study of the Mahushe Shongwe Game Reserve. Geoforum, 38(1), 207-219.

Kovach, M. (2009). Indigenous methodologies: characteristics, conversations and contexts. University of Toronto Press.

Lahiff, E. (2007). 'Willing buyer, willing seller': South Africa's failed experiment in market-led agrarian reform. Third World Quarterly, 28(8), 1577-1597.

Leach, M. \& Mearns, R., (1996). The Lie of the Land: Challenging Received Wisdom on the African Environment. London, UK. Indiana University Press.

Lester, A. (1998). 'Otherness' and the frontiers of empire: the Eastern Cape Colony, 1806- 1850. Journal of Historical Geography, 24(1), 2-19.

Lindsey, P. A., Alexander, R., Frank, L. G., Mathieson, A., \& Romanach, S. S. (2006). Potential of trophy hunting to create incentives for wildlife conservation in Africa where alternative wildlife-based land uses may not be viable. Animal Conservation, 9 (3), 283291.

Lindsey, P. A., Roulet, P. A., Romanach, S. S. (2007). Economic and conservation significance of the trophy hunting industry in sub-Saharan Africa. Biological conservation, 134(4), 455-469. 
Longhurst, R. (2003). Semi-structured interviews and focus groups. Key methods in geography, 3, 143-156.

MacDonald, M. (2006). Why race matters in South Africa. Harvard University Press.

MacKenzie, J. M. (1997). The empire of nature: Hunting, conservation and British imperialism. Manchester University Press.

McCusker, B., \& Carr, E.R. (2006). The co-production of livelihoods and land use change: Case studies from South Africa and Ghana. Geoforum, 37(5), 790-804.

McCusker, B., Moseley, W. G., \& Ramutsindela, M. (2015). Land reform in South Africa: An uneven transformation. Rowman \& Littlefield.

McDermott, D. (2005). Third Nature: Making Space and Time in the Great Limpopo Conservation Area. Cultural Anthropology, Vol. 20, No. 2.

McGuigan, L. (2017). The hunting industry: Exploring the marriage of consumerism, sport hunting, and commercial entertainment. Journal of ConsumerCulture, 17(3), 910-930.

Moore, D. S., Kosek, J., \& Pandian, A. (Eds.). (2003). Race, nature, and the politics of difference. Duke University Press.

Moyo, S. (2008). African land questions, agrarian transitions and the State: contradictions of neoliberal land reforms. African Books Collective.

Ndebele, N. (1998). Game lodges and leisure colonialists. Blank-Architecture, Apartheid and After $C, 10$.

Neumann, R.P. (1998). Imposing wilderness: struggles over livelihood and nature preservation in Africa (Vol. 4). University of California Press.

Peet, R. (2007). Geography of Power. Zed Books.

Peet, R. (2002). Ideology, discourse, and the geography of hegemony: From socialist to neoliberal development in postapartheid South Africa. Antipode, 34(1), 54-84.

Peet, R., \& Watts, M. (2004). Liberation ecologies: environment, development, social movements (2nd ed.). Routledge.

Peluso, N. L., \& Lund, C. (2011). New frontiers of land control: Introduction. Journal of Peasant Studies, 38(4), 667-681.

Pinnock, Don. (August 8 2019). Court victory for NSPCA over welfare of captive lions, 
bone exports. Retrieved August 2019 from https://conservationaction.co.za/media-articles/court-victory-for-nspca-overwelfare-of-captive-lions-bone-export/

Ramutsindela, M. (2012). Property rights, land tenure and the racial discourses. GeoJournal, 77(6), 753-763.

Ramutsindela, M. (2003). Land reform in South Africa's national parks: a catalyst for the human-nature nexus. Land use policy, 20(1), 41-49.

Robbins, P. (2011). Political ecology: a critical introduction. Malden, MA: Blackwell Pub.

Safari Club International First for Hunters Online Record Book. Retrieved October 2018 from www.scirecordbook.org/species/index.cfm/

Said, E. (1978). Orientalism. Random House.

Saayman, M., van der Merwe, P., \& Saayman, A. (2018). The economic impact of trophy hunting in the South African wildlife industry. Global Ecology and Conservation, 16, e00510.

Sharp, J. P. (2008). Geographies of postcolonialism: spaces of power and representation. Los Angeles: SAGE.

Smith, N. (2008). Uneven development: Nature, capital, and the production of space. University of Georgia Press.

Snijders, D. (2012). Wild property and its boundaries — on wildlife policy and rural consequences in South Africa. Journal of Peasant Studies, 39(2), 503-520.

Snijders, D. (2015). Shifting species in South Africa: wildlife policy, rural consequences.

Soja, E. W. (1971). The Political Organization of Space, Commission on College Geography Resource Paper No 8, Washington: Association of American Geographers.

Spierenburg, M., \& Brooks, S. (2014). Private game farming and its social consequences in post-apartheid South Africa: contestations over wildlife, property and agrarian futures. Journal of Contemporary African Studies, 32(2), 151-172.

Stevens, S. F., \& Dean, T. D. (1997). Conservation through cultural survival: Indigenous peoples and protected areas. Island Press.

Taylor, A. N. D. R. E. W., Lindsey, P. A., Davies-Mostert, H. A. R. R. I. E. T., \& Goodman, P. E. T. E. R. (2016). An assessment of the economic, social and 
conservation value of the wildlife ranching industry and its potential to support the green economy in South Africa. The Endangered Wildlife Trust,

Johannesburg, 96-109.

TREES. 2017. A marketing and spending analysis of trophy hunters 2015/2016 season, Tourism Research in Economic Environs and Society, North-West University, Potchefstroom, South Africa.

Van der Merwe, P., Saayman, M., \& Rossouw, R. (2014). The economic impact of hunting: A regional approach. South African Journal of Economic and Management Sciences, 17(4), 379-395.

Waugh, L. R., Catalano, T., Al Masaeed, K., Do, T. H., \& Renigar, P. G. (2016). Critical discourse analysis: Definition, approaches, relation to pragmatics, critique, and trends. In Interdisciplinary studies in pragmatics, culture and society (pp. 71 135). Springer, Cham.

West, P. and J.G. Carrier (2004) 'Ecotourism and Authenticity: Getting Away from It All?', Current Anthropology 45(4): 483-98.

Wildlife Ranching South Africa: Who is WRSA? Retrieved from https://www.wrsa.co.za/goals-who-is-wrsa/

Williams, V. L., Newton, D. J., Loveridge, A. J., \& Macdonald, D. W. (2015). Bones of contention: an assessment of the South African trade in African lion Panthera leo bones and other body parts. TRAFFIC, Cambridge, UK\& WildCRU, Oxford, UK. 
"You know I'll be completely honest. Our mindset and our approach is that game and animals are animals; they produce to be utilized by man, and provided that what you do you do in a responsible way, you may utilize. So you would very seldom get the question being asked around the value of the life of an animal." - member of South Africa Hunting and Game Conservation Association (SAHGCA)

Although the above was quoted in 2018, it could easily have been said in the mid$20^{\text {th }}$ century, but with one important distinction: today's utilization of nonhuman animals has moved beyond domestic livestock for food production. It now encompasses "game," or wild species that are produced to be hunted sometimes for food but more significantly for recreation and the accumulation of private profit under the guise of conservation.

The privatization and commodification of nature have intensified through discourses of neoliberalism and sustainable development, which frame environmental repair as one made possible through a capacity for superior ecological stewardship and free market environmentalism (Ramutsindela and Shabangu, 2013; Castree, 2008; Harvey, 2005). South Africa's most recent iteration of conservation lessens the role of the state and places the onus of economic and environmental sustainability onto the private sector, operating under the logic that private landowners have the ability and skills to more efficiently manage natural resources (Ramutsindela and Shabangu, 2013). This neoliberal shift allowed them entry into national conversations that directly influence wildlife management policy today (Cousins et al., 2010). Discourses that land must be valued according to market principles reaches its apex when state authorities and wildlife practitioners decry how land is "under utilized," which triggers a higher concentration and accumulation of capital in the hands of private landowners, or results in state sanctioned green grabbing (Spierenburg and Brooks, 2014; Fairhead et al., 2012).

Framing the value of nature in utilitarian and economic terms greenwashes exploitative practices and ultimately engenders uneven consequences for nonhuman animals. These outcomes materialize on account of Western epistemologies, discourses, and legislation that operate spatiotemporally at various scales. The violence of trophy hunting and the intensification of breeding wildstock in South Africa at the local level links inextricably with state and international environmental policies and the broader neoliberal economy, at which all living things have a value that shift according to supply and demand. Ascribing a monetary value to a specific species at a given time may mean that some nonhuman lives end more abruptly and unceremoniously than others, such as the case with culling, put and take, and canned hunting. If the value of a species or subspecies plummets on account of an over-saturated market and economic bubble, nonhumans, such as color variant species, may be released prematurely onto extensive enclosures to fend for themselves. In industry terms, "If it pays, it stays."

The intensification of wildstock breeding allows the trophy hunting industry to prosper, as wildlife ranchers supply landowners, game farmers, and safari outfitters with a sustainable bounty of nonhumans to restock their "harvest". Managing wildlife in this way is understood as a natural byproduct of a nature (re: neoliberal nature) beset by 
fences. In some cases breeding wildstock in intensive enclosures causes environmental damage and leads to poor health conditions for nonhumans (personal observations), as ranchers particularly new to 'farming the wild' sometimes fail to properly rotate land for grazing. Wildlife owners are obligated under national legislation (NEMBA and Animal Improvement Act) to replenish and ensure a sustainable and diverse gene pool, but doing so is also essential to their livelihood production. In a competitive regional market where international trophy hunters target exotic species based on color variation and the size of horns, tusks, and bosses (particular to African buffalo), restocking nonhuman animals becomes less about conservation or selecting particular genes for the purposes of protecting indigenous fauna. Rather, "conservation" is motivated by the accumulation of profit, which reduces nonhumans to capitalist abstractions and itemized body parts, and overall compromises nonhumans' ability to select naturally for themselves. Indeed, the production of nonhumans from birth to death involves a great deal of human intervention, which includes veterinary exams and vaccinations, and darting for genetic analysis samples, data collection such as weight and horn length, and capture and transportation to auctions and new nature enclosures.

The argument for the intense management and manipulation of nonhumans and the environs they inhabit is situated not only in contradictory conservation claims but also discourses that link sustainable development and ecosystems services to South Africa's green economy. Private landowners that shifted from agricultural production to wildlife production who demonstrate a commitment to conservation and social transformation are better able to maintain relevance in South Africa's political economy, which in essence provides them with a protective barrier from land expropriation without compensation. As signatory to the Convention on Biological Diversity (CBD, 1992), South Africa is obligated to meet its international commitments to nature conservation. Demonstrated commitment to meet these obligations, in addition to Sustainability Development Goals (SDG), may stimulate economic investment and lead to international support for project and skill development, and expertise and knowledge transfer. Under this economic regime we can see how redressing the colonial legacies of displacement, dispossession, and the accumulation of private land become less a priority, and hence increasingly intractable.

Despite its private entrenchment, the economic aspects of wildlife ranching and the proliferation of game farms that accommodate trophy hunting should not be altogether dismissed. Saayman et al. (2018) highlights the industry's contributions to the development of tourism, wildlife, and agricultural services, such as food and accommodation, games capture and transportation, and meat processing. Trophy hunting supports more than 17, 000 job opportunities in South Africa (Saayman et al., 2018). A number of businesses benefit greatly from domestic hunters and international hunting clientele, who spend their money on hunting equipment, guns, ammunition, telescopic sights, clothing, and taxidermy (Saayman et al., 2018). This is no more evident than at large scale hunting shows such as Safari Club International's Annual Hunter's Convention (SCIAHC), where mostly white and wealthy trophy hunters peruse a conglomeration of taxidermy and guns and select their next big game hunting adventure. No consumer space quite captures the convergence of capitalism, conservation, and colonialism so well. In this space right wing ideologies, myths, and discourses interface 
with market logics and the hegemon of traditional Western conservation to greenwash, fetishize, and commodify nature.

Trophy hunting conventions such as this are unequivocally political. Industry advocates exploit the politically divisive nature of hunting through discourses of difference meant to strengthen cultural identity bonds and an Us vs. Them mentality, which act to promote outrage, fear, and attitudes of cultural superiority. Framing the political left as a monolith of ignorant urbanites bent on taking away one's guns, and therefore their ability to hunt, stirs up fears of losing their cultural heritage and way of life. Invocations of neo-Malthusian and cultural myths grounded in colonialism, American militarism, $2^{\text {nd }}$ Amendment rights, and the North American model of conservation collectively reinforce stereotypes, whitewash history, and foster a consensus: only trophy hunting (mostly white) can resolve human-wildlife conflict, rural poverty, overpopulation, and food insecurity in the Global South.

Last year's Safari Club International's Annual Hunter's Convention raised US\$1.5 million, which it has used to lobby for greater influence as member of the IUCN, and fundamental changes to the Endangered Species Act and Antiquities Act which would loosen wildlife protections, environmental regulations, and open up new territories for market expansion. According to SCI, American hunters retain the "right" to hunt wherever they please, meaning that efforts that interfere with hunting will be met with resistance. Believing that one has the right to go anywhere in the world to take what is "rightfully theirs" reflects a colonial attitude, a demonstrative sense of entitlement illustrative of privilege and a lack of self-awareness. In this context, I'd argue that SCI's political strategies and attitudes undermine their own efforts to support development and anti-poaching initiatives in the Global South. According to one research participant, the politicization of hunting and SCI's partnership with the National Rifle Association may account for why some game farmers in South Africa are not interested in attending these events.

There are other reasons for disinterest in participating in SCIAHC. Some farmers are already well established and can rely upon word of mouth to stay booked throughout the hunting season. For less established farmers it may prove cost prohibitive. Still others are less interested in SCIAHC due to what industry practitioners generally refer to as "inch chasers." As hunters age they become more discerning about what they hunt, as they have entered into stage three of their hunting careers, or what is otherwise known as the collection stage. This implies that a hunter gives greater consideration to quality than quantity, and the sustainability of the harvest. These trophy collectors may be thinking about where the trophy will be placed in their man cave prior to or during the hunt. This hunter may be drawn to "representative animals" of a certain species, while others are more interested in size and killing an animal with bigger horns than the ones their coworkers, employees, or friends have killed. Still others are motivated by recognition in SCI's record book. One interviewee referred to the motivation to hunt based on horn size "as a bit false at the moment" and attributed it to how SCI markets trophy hunting. Some have admitted that it amounts to "bragging rights" amongst pals and co-workers, which I would argue constitutes a masculine performativity. Masculinity indeed has its place in trophy hunting, and has prompted more traditional hunters in the industry to suggest international trophy hunters refrain from posting photos on social media that depict 
themselves as conquerors. The assumption is that these photographs communicate a toxic form of masculinity, and remind critics of its violent and colonial nature.

For international trophy hunters, however, the colonial aspect is not particularly bothersome. It's quite the contrary. South African wildlife ranchers and African safari outfitters in general recognize the allure and romanticism of the colonial past. At SCIAHC, they hang up photos of Teddy Roosevelt standing in front of felled elephants (black and white) and peopleless African landscapes, and an assortment of material objects such as ivory tusks, taxidermy, colonial tents, old camping chairs, and zebra-skin rugs to attract potential clients. Some of their websites use language that refers to Africa as a monolith, invoking the "dark continent" to give the impression of danger, colonial adventure, and that one's white presence will help subsidize the economic development of poor Africans and contribute to conservation.

Research has shown that international trophy hunters are concerned that their money contributes in some way to conservation and development (Lindsey et al., 2006). But at what cost? The expansion of neoliberal logics in South Africa has furnished a wildlife economy whereby species are produced to meet specific body traits, which has resulted in a boutique market amplifying the accumulation of greater wealth for private landowners. Rural Africans have been alienated from their labor and have limited access to land. Because wildlife is now privately owned and protected behind a network of neoliberal fences, subsistence hunting is effectively closed off to landless South Africans who are unable to subsidize their diets through hunting (which would also help resolve the "poaching" problem). There's a substantial difference between subsistence hunting and producing "wild" nonhuman specimens with specific traits to be shot for the purpose of festooning one's walls with dead animals thousands of miles away.

Goodrich (2016: 1) argues "hunting 'nature' is a commodity that anchors a past nationalist masculine hierarchy in a reciprocal relationship to game on privately owned land and collapses belonging into ownership." In this view, a collective sense of belonging to the landscape legitimizes white landowners to further "consolidate and (re)assert their claims to private property" (Spierenburg and Brooks, 2014). For this reason I believe the continued spatialization of South Africa on account of nature saving (Buscher et al., 2012) represents a colonial present (Joseffson, 2014), or rather a "cultural repertoire projecting moral geographies of the colonial past onto the present landscape" (Gregory, 2004).

Frontiers of hunting, livestock management, and resource extraction were all very powerful symbols for new nations and masculinities (Beinart and Coates, 2002), and remain enduring symbols of success, fortitude, and colonialism today. Preservation of a spatially colonial past depends upon a spatiotemporal politicization of identity, which occurs at multiple scales. Wildlife ranchers may scale up their identity to the African continent, discursively framing themselves as a colonized feminine Africa subject to the imposition of a masculinized West. At the same time they drive narratives that help stabilize their white and Western identity. Ironically, the industry justifies its practices and ongoing accumulation of land, wildlife, and profit based on colonial epistemologies and ahistorical explanations that place race and racial bias at the location of nature commodification. They also capitalize on neoliberal discourses that greenwash the contradictions of capital. 
The ultimate paradox is the notion that humans must employ a capitalist approach that normalizes the killing of nonhumans to save nature from capitalism. In this economic system nonhumans are incessantly manipulated and live to die in games of human recreation. There are far too many ethical loopholes in the wildlife economy, which trophy-hunting advocates readily admit. These threaten to destabilize the industry. Put and take and canned hunting are not only blemishes on South Africa's brand, but are objectionable practices deserving of fines, penalties, and suspended licenses. There is no reason for anyone to consider these activities recreational, unless we're prepared to say that killing is a valid recreational pursuit (Gewald et al., 2018). By simply calling nonhumans "game" we open them up for greater exploitation. Depending on use of language and the power that determines how concepts and practices are defined and thus regulated, nonhuman animal lives are reduced to economic abstractions, and are made ready to be killed at the altar of capitalism.

\section{Shortcomings}

My intention was to interview and observe international hunters on safari. Getting permission to accompany trophy hunters was problematic, and if given permission, observer fees were very expensive and I lacked the necessary funding.

Research proved even more difficult at times given the disclosure of my preliminary conceptual framework that was initially broadcast on a podcast and circulated amongst industry actors in South Africa. Generally, a lack of trust characterizes the industry, operating under the assumption that academic critique typically mischaracterizes trophy hunting and threatens livelihoods. Many industry actors are suspicious of academics and journalists, as well as activists, which is why many safari outfitters no longer share contact information of former clients on their online websites. Initially I identified international trophy hunters on safari operator websites through hunter testimonials, which is where satisfied clients share their positive experiences and contact information for trophy hunters searching for a safari operator they can trust. Recipient response was low: approximately $90 \%$ did not respond, while nearly the remaining $10 \%$ requested not to be contacted again. The remainder questioned who I was or requested my advisor's contact information to prove that I was an academic with "good intentions." While in South Africa one game breeder agreed to participate in my research provided that my findings about their operation would not be published without their review and consent. I believe this speaks to the very political nature of this research inquiry, as well as the potential legal ramifications for me personally should the research participant not find the data favorable. So I remain indebted to the small number of game farmers, wildlife ranchers, and game managers who believe that the only way to change negative public perception is to be open and honest about what they do.

\section{Recommendations}

As the market for color variants such as impala comes back down to earth, wildlife ranchers are removing fences from intensive enclosures. I recommend following up to see how this may impact the consolidation of farms. As more wildlife ranchers lose 
money, how will this impact the industry? Will wildlife ranchers diversify land and wildlife production to survive? Will they bring cattle back onto their farms? What impact will this have on the sale and trade of wildlife, such as auctions? And what impact will this have on tourism and local economies?

Using a post-colonial lens, I also recommend further research regarding the connections between the US military and conservation, particularly how and why former military personnel offer their services to fight the war for diversity in South Africa and elsewhere abroad. This would help expand on Ramutsindela and Buscher's (2015) concept of green violence, and deepen our understanding of how political identities operate in international conservation.

It's well known that hunter numbers are decreasing in the US. Consequently, the gun and hunting industry target women. How specifically does the hunting industry market trophy hunting to women? How do the motivations of male and female trophy hunters differ? While the masculinity of hunting is well known, very little geographical research has been offered regarding women in hunting.

Much research also remains to be done regarding the wildlife ranching industry in the United States. Many trophy hunters note the cultural and physical geographical similarities between South Africa and places like Texas. Indeed, there's a certain familiarity amongst US trophy hunters that may cause them to go to South Africa. But what happens on US ranches? What do social relations look like on US ranches? How are these ranches marketed? What species are bred for trophy hunting? What drives the industry here in the US?

I also recommend comparing and contrasting South Africa as a hunting destination with their regional rivals. What is it about Zimbabwe or Tanzania that's different for Western trophy hunters? Do Zimbabweans market their "product" any differently than South Africans?

Aside from some relatively recent literature, such as Mbaiwa (2018), little research has been done about trophy hunting from a non-white perspective in South Africa or elsewhere. This is perhaps the greatest limitation of my research project, especially as I see myself as an activist for decolonization. When visiting my Peace Corps village last year in Logaganeng, not a few friends and family asked me why white people want to come to their country to kill animals. It seemed foreign and violent to them, as they lived far from any protected area or reserve. This raises questions about people living adjacent to trophy hunting farms. In other words, how do local populations who live in close proximity to wildlife ranches perceive the practice of trophy hunting? How do these perceptions change according to place and conservation model (private vs. community) at different scales? The answers to these questions may elicit deep understandings of uneven power relations, cultural identity, and the geography of conservation.

Lastly, and perhaps most importantly, there remains a much-needed analysis in terms of how the devaluation of and violence against nonhumans are part of a longer historical violence against black South Africans. This research project and the findings therein provide an excellent foundation for critically engaging the dehumanizing processes that make subjugation and exploitation possible and justifiable against humans and nonhumans alike. As such, I'd be remiss not to make a call for such an important future work. 


\section{Works Cited}

Beinart, W., \& Coates, P. (1995, 2002). Environment and history: The taming of nature in the USA and South Africa. Routledge.

Brandt, F., \& Spierenburg, M. (2014). Game fences in the Karoo: reconfiguring spatial and social relations. Journal of Contemporary African Studies, 32(2), 220-237.

Buscher, B., Sullivan, S., Neves, K., Igoe, J., \& Brockington, D. (2012). Towards a synthesized critique of neoliberal biodiversity conservation. Capitalism Nature Socialism, 23(2), 4-30.

Büscher, B., \& Ramutsindela, M. (2015). Green violence: Rhino poaching and the war to save Southern Africa's peace parks. African Affairs, 115(458), 1-22.

Castree, N. (2008). Neoliberalizing nature: processes, effects, and evaluations. Environment and planning A, 40(1), 153-173.

Cousins, J. A., Sadler, J. P., \& Evans, J. (2010). The challenge of regulating private wildlife ranches for conservation in South Africa. Ecology and Society, 15(2).

Fairhead, J., Leach, M., \& Scoones, I. (2012). Green Grabbing: a new appropriation of nature?. Journal of Peasant Studies, 39(2), 237-261.

Gewald, J. B., Spierenburg, M., \& Wels, H. (2018). Nature conservation in southern Africa: Morality and marginality: Towards sentient conservation?. Brill.

Goodrich, A. (2016). Enacting and stabilizing the nature of colonial history through hunting in the South African Highveld. Journal of Contemporary African Studies, 34(1), 22-39.

Gregory, D. (2004). The Colonial Present: Afghanistan, Palestine, Iraq (pp. 1-15). Malden, MA: Blackwell Pub.

Harvey, D. (2005). From globalization to the new imperialism. Critical globalization studies, 91-100.

Josefsson, J. (2014). Safe-guarding the colonial present: game farms on the frontier in KwaZulu-Natal's 'Battlefields Route'. Journal of Contemporary African Studies, 32(2), 258-274.

Lindsey, P. A., Alexander, R., Frank, L. G., Mathieson, A., \& Romanach, S. S. (2006). Potential of trophy hunting to create incentives for wildlife conservation in Africa where alternative wildlife-based land uses may not be viable. Animal Conservation, 9 (3), 283291. 
Mbaiwa, J. E. (2018). Effects of the safari hunting tourism ban on rural livelihoods and wildlife conservation in Northern Botswana. South African Geographical Journal, 100(1), 41-61.

Ramutsindela, M., \& Shabangu, M. (2013). Conditioned by neoliberalism: a reassessment of land claim resolutions in the Kruger National Park. Journal of Contemporary African Studies, 31(3), 441-456.

Saayman, M., van der Merwe, P., \& Saayman, A. (2018). The economic impact of trophy hunting in the South African wildlife industry. Global Ecology and Conservation, 16, e00510.

Spierenburg, M., \& Brooks, S. (2014). Private game farming and its social consequences in post-apartheid South Africa: contestations over wildlife, property and agrarian futures. Journal of Contemporary African Studies, 32(2), 151-172. 